\author{
Universidade de São Paulo \\ Instituto de Astronomia, Geofísica e Ciências Atmosféricas \\ Departamento de Astronomia
}

Mônica Bandecchi da Fonseca Vieira

\title{
Astrofísica Estelar para o Ensino Médio: análise de uma proposta
}

São Paulo

2018 
Mônica Bandecchi da Fonseca Vieira

\section{Astrofísica Estelar para o Ensino Médio: análise de uma proposta}

Dissertação apresentada ao Departamento de Astronomia do Instituto de Astronomia, Geofísica e Ciências Atmosféricas da Universidade de São Paulo como requisito parcial para a obtenção do título de Mestre em Ciências.

Área de Concentração: História da Astronomia e da Cosmologia.

Orientador: Prof. Dr. Jorge Ernesto Horvath

Coorientador: Prof. Dr. Paulo Sergio Bretones

Versão Corrigida. O original encontra-se disponível na Unidade.

São Paulo 


\section{Agradecimentos}

Primeiramente, a meu marido, Victor, que sempre acreditou em mim e me incentivou nas etapas importantes de minha vida, inclusive na realização deste trabalho.

A meus pais e familiares por sempre estarem a meu lado me apoiando em minhas decisões.

A meus amigos, que me deram forças para realizar mais esta etapa, e às novas amizades formadas durante este processo, principalmente a meus colegas do MPEA, com quem compartilhei ótimos momentos.

A meu orientador, Prof. Dr. Jorge Ernesto Horvath, que me acompanha desde a graduação. Agradeço pelas orientações, pela paciência e pelas risadas durante este período. Obrigada por acreditar em mim e tornar possível este sonho.

A meu coorientador, Prof. Dr. Paulo Sergio Bretones, por aceitar entrar nesta "aventura" comigo. Suas conversas e suas orientações foram fundamentais para a finalização desta pesquisa.

Ao Instituto de Astronomia, Geofísica e Ciências Atmosféricas e aos professores do Programa de Mestrado Profissional em Ensino de Astronomia por me acolherem e me integrarem nesta comunidade, da qual sempre tive tanto orgulho.

À professora Mônica Lemos da E. E. Prof. Gabriel Ortiz, que me acompanhou durante as aulas realizadas na escola, pelo interesse em fazer com as aulas ocorressem da melhor forma.

Por fim, agradeço à E. E. Prof. Gabriel Ortiz, onde realizei o Ensino Médio e apliquei o projeto desta pesquisa, por ter contribuído para minha formação e ceder o tempo e o espaço para a realização deste trabalho. 
Ensinar é um exercício de imortalidade. De alguma forma continuamos a viver naqueles cujos olhos aprenderam a ver o mundo pela magia da nossa palavra. O professor, assim, não morre jamais...

\section{Rubem Alves}




\section{RESUMO}

O presente trabalho visa apresentar uma proposta e uma breve análise do potencial pedagógico do tema da Astrofísica Estelar, uma vez que a teoria da formação e da evolução das estrelas é uma fusão da Astronomia com a chamada "Física Moderna". O assunto proposto está idealmente situado para iluminar e reforçar a base física do Ensino Médio (termodinâmica básica, propriedades da luz, gravitação newtoniana etc.) por meio dos conceitos da Astrofísica Estelar na escola, já que eles se relacionam com o conteúdo que os alunos estavam aprendendo naquele momento. O trabalho se desenvolveu a partir da realização de quatro aulas aplicadas em cinco turmas da 2. ${ }^{a}$ série do Ensino Médio, que tinham, no total, 69 alunos, em uma escola pública da cidade de São Paulo. O tema das aulas se relacionou com a formação e a evolução estelar; porém, também discorreu-se sobre questões mais gerais da Astronomia, como as constelações e o conceito de galáxia, a fim de introduzir o assunto para os estudantes. Toda a atividade foi elaborada a partir de uma apresentação de slides enriquecida com imagens e simulações. Como fonte de dados, utilizou-se um Questionário Inicial e um Final, aplicados durante a atividade, além da gravação das aulas e de outras anotações, sendo a pesquisadora a própria professora da turma. Analisou-se o aprendizado do grupo como um todo e a evolução conceitual de alguns alunos ao longo das aulas. Identificou-se defasagem nos conteúdos de Física dos alunos. Nesse sentido, as aulas sobre estrelas contribuíram de alguma maneira para o aprendizado dos estudantes, conforme verificado. Os resultados mostraram um progresso significativo, destacando-se alguns conceitos físicos agora integrados, tais como a luz e a gravitação.

Palavras-chave: Ensino de Astronomia. Ensino de Física. Astrofísica Estelar. 


\begin{abstract}
This study aims to present a proposal and a brief analysis on the pedagogic potential of Stellar Astrophysics, since the theory of formation and evolution of stars is a merger of astronomy and the so-called "Modern Physics". The proposed theme is ideally posted to enlighten and enhance the high school basic physics (basic thermodynamics, properties of light, Newtonian gravity, etc.), addressing stellar astrophysics concepts at school, since they relate to the subjects the students are learning simultaneously. The work has been developed through the application of four lessons for five different second year high school groups of students, totaling 69 students from a public school in the city of São Paulo. The subject of the lessons was related on star formation and stellar evolution, although more general topics related to astronomy were also addressed, such as constellations and the concept of galaxy, in order to introduce the topics to the students. All activity was developed through a slide show enriched with images and simulations. For the data survey, initial and final questionnaires were used during the activity, in addition to the classes records and other notes, being the researcher the class teacher. An analysis of the learning of the group as a whole was made as well as a study of the conceptual evolution of some students throughout the classes. We identified a discrepancy in students' physical contents. For that matter, the lessons about star contributed somehow to the students' learning, as verified. The results showed a significant evolution, highlighting some physical concepts now integrated, such as light, gravitation and others.
\end{abstract} Keywords: Astronomy Education, Physics Education, Stellar Astrophysics. 


\section{SUMÁRIO}

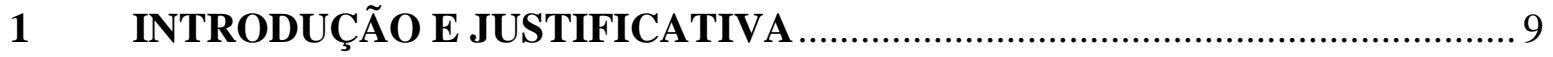

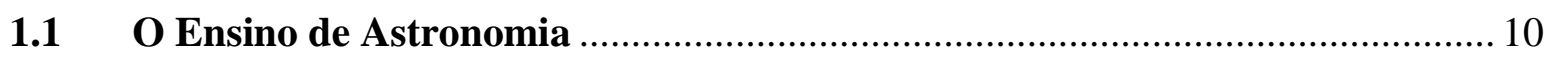

1.2 Astrofísica Estelar na educação básica ...................................................... 11

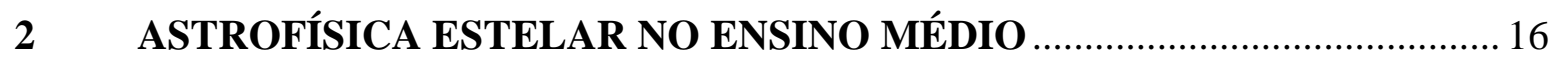



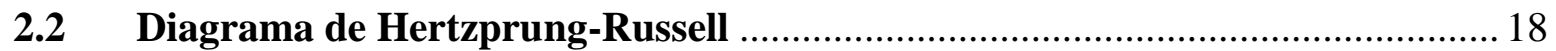

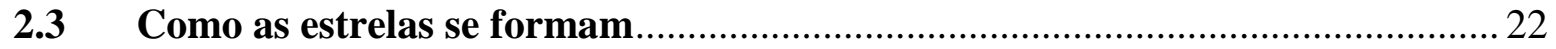

2.4 A partilha da energia na nuvem: o Teorema do Virial ................................ 24

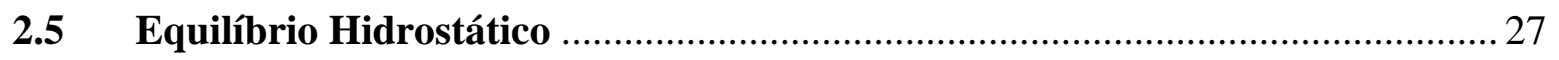

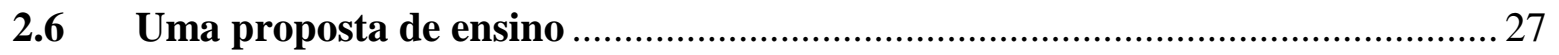



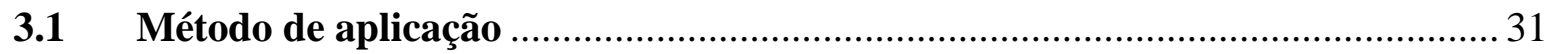

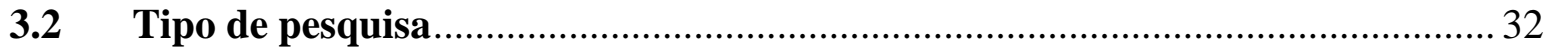

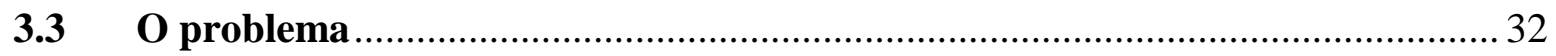

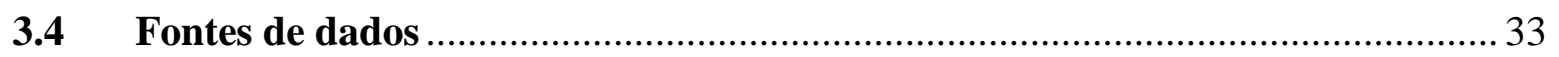

3.5 Referencial Teórico para análise dos dados ............................................... 34

$4 \quad$ ANÁLISE DOS DADOS E DISCUSSÃO ................................................ 35

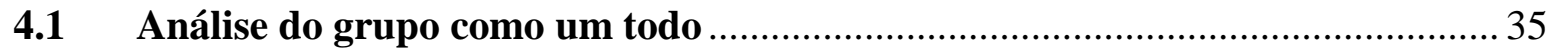

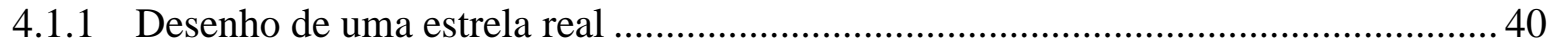

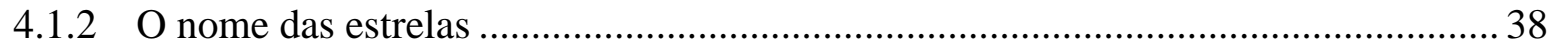

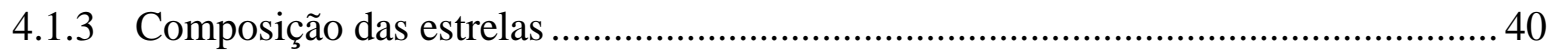

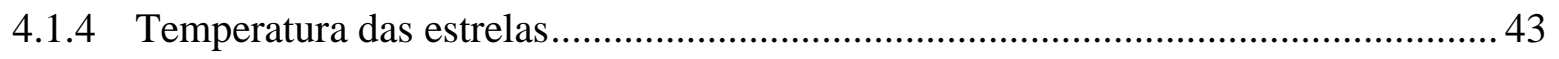

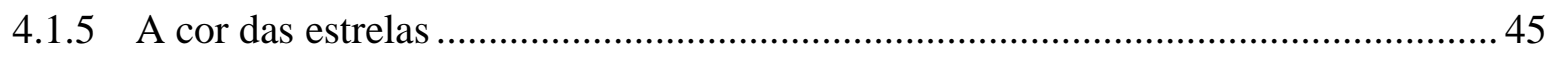

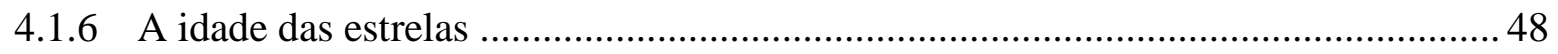




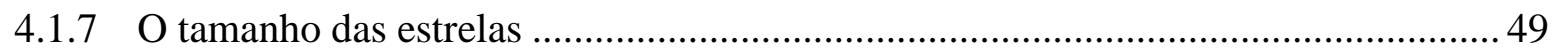

4.1.8 Radiação e fusão nuclear ....................................................................... 52

4.1.9 Equilíbrio Hidrostático .......................................................................... 54

4.1.10 Formação estelar e importância da luz para as estrelas ......................................... 57

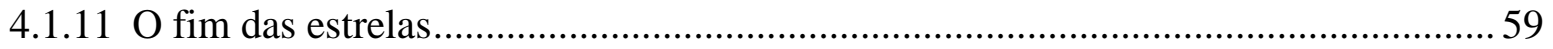

4.1.12 A importância da gravidade no ciclo estelar......................................................... 61

4.1.13 Formação dos elementos químicos nas estrelas.............................................. 63

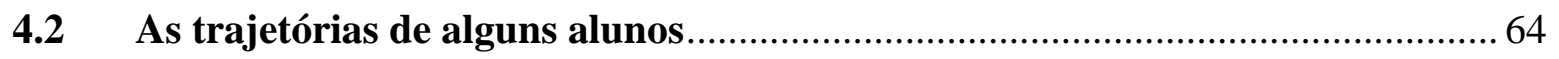

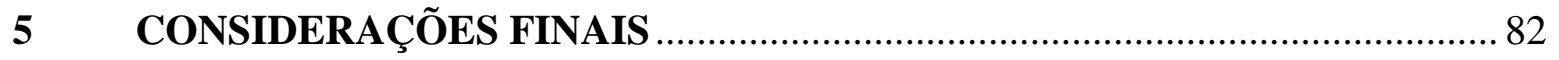

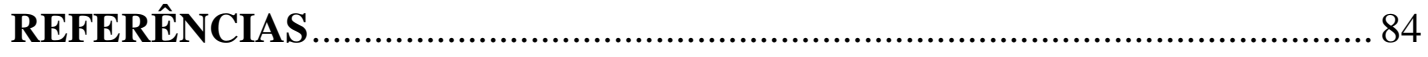




\section{INTRODUÇÃO E JUSTIFICATIVA}

A astronomia é considerada uma das primeiras ciências estudadas pela humanidade. Desde os primórdios, o homem observa o céu com a finalidade de encontrar respostas para as dúvidas mais fundamentais sobre sua existência: de onde viemos? Para onde vamos? Como surgiu o universo? O que o compõe?

A compreensão que temos desses assuntos se aprimorou ao longo do tempo. Hoje, devido ao desenvolvimento da tecnologia, podemos obter informações de objetos que estão a distâncias extremas da Terra. É até mesmo possível coletar dados sobre a origem do universo, o chamado Big Bang. Tudo isso se deve ao aperfeiçoamento dos estudos e ao consequente avanço no conhecimento sobre o cosmos.

Apesar da importância da Astronomia, percebemos uma desvalorização desta e de outras ciências em geral nos últimos tempos; portanto, resulta razoável perguntarmos o que a sociedade transmite hoje para as futuras gerações sobre esses fatos. No que se refere à educação formal, tópico tratado a seguir, o ensino de Astronomia possui grandes deficiências.

De acordo com os Parâmetros Curriculares Nacionais (PCN), o ensino dessa área do saber possui papel importante para a finalização da educação básica, pois está diretamente relacionado com a história geral da ciência e contribuiu significativamente para o aprimoramento e o desenvolvimento científico ao longo do tempo (BRASIL, 2000). A compreensão do universo - bem como de sua origem, da radiação cósmica, das escalas astronômicas de tempo e espaço, dos planetas - são aspectos dessa temática que despertam o interesse dos jovens, algumas vezes, por ter relação com assuntos fundamentais, por exemplo, a origem do universo e da vida (BRASIL, 2006; HORVATH, 2008).

Entretanto, o estudo da Astronomia e da Astrofísica, em especial dos tópicos que vão além do sistema Sol-Terra-Lua, necessita progressivamente da utilização de instrumentos de alta tecnologia, que, na maioria das vezes, distancia o estudante e o faz perder o interesse ou o induz a aceitar uma série de afirmações e resultados que não estão próximos de sua experiência direta. Além disso, a falta de incentivo ao professor e seus diversos problemas enfrentados no exercício da profissão prejudicam ainda mais o ensino dessa área do conhecimento. Muitas vezes, a Astronomia nem sequer é apresentada para os estudantes, causando um déficit importante na educação dos jovens (BAZETTO; BRETONES, 2011). 
Isso é particularmente intrigante, já que algumas das principais teorias da física advêm do estudo de fenômenos astronômicos ou são diretamente aplicáveis a eles, como as leis da radiação, da gravitação, da relatividade, da termodinâmica, da física dos núcleos, etc. Outros estudos relacionados à mecânica de corpos, como a lei da inércia, também possuem forte ligação com a Astronomia (CANIATO, 2011; LANGHI; NARDI, 2010). A presença da Física e a importância dada a esta no currículo escolar é muito maior que aquela atribuída à Astronomia. Essa assimetria causa todo tipo de problemas, incluindo um viés que distorce o desenvolvimento histórico das ciências e cria uma ilusão de "compartimentos separados", fortemente negativa.

Embora seja mencionado nos PCN, a relação Física-Astronomia e vice-versa não é apresentada aos estudantes. Além disso, o estreito vínculo da Astrofísica Estelar e da Cosmologia com a Física do século 20 é ignorado até mesmo nas aulas de Física, nas quais raras vezes essa simbiose é discutida.

Sabemos que muitos dos objetos e dos dispositivos presentes em nossa rotina são consequências do aperfeiçoamento de instrumentos utilizados no estudo da Astronomia e das Ciências Espaciais, como aparelho de GPS, painéis solares, câmaras de ressonância magnética (assim como outras tecnologias aplicadas na Medicina), computadores pessoais, celulares, microlaser, lentes para óculos com proteção UV, entre muitos outros instrumentos que facilitam o avanço de nosso conhecimento, contribuem para esse progresso e modelam nossas vidas. Dessa forma, é possível perceber que estudar Astronomia não só colabora com o aperfeiçoamento do saber que temos sobre o universo, mas também impulsiona evoluções na economia e nos recursos tecnológicos de um país (CANIATO, 2011).

\subsection{O Ensino de Astronomia}

Embora o estudo da Astronomia seja muito antigo, no Brasil, especialmente em instituições de educação básica públicas, o ensino formal apresenta considerável déficit no que diz respeito a essa área do conhecimento. O conteúdo de tal campo nas salas de aula,

quando presente, é muito insuficiente. No que se refere à formação de professores, apenas alguns cursos de graduação possuem disciplinas de Astronomia em sua grade obrigatória (AROCA; SILVA, 2011). 
Esse campo possui grande potencial interdisciplinar. Pode se encontrar com grandes áreas das ciências da natureza, como a Física, a Matemática, a Química, a Geologia e até a Biologia, a fim de fazer uma mesma análise: estudar a origem do Sistema Solar. Tal relação pode considerar a formação do Sol (Física, Matemática e Química) e dos planetas (Geofísica e Geologia), além da origem da vida na Terra (Biologia). Esses exemplos são somente uma amostra do potencial mencionado.

Existe um número expressivo de eventos nacionais realizados, na maioria das vezes, em universidades públicas, direcionados à Astronomia, nos quais são discutidos diversos tópicos ligados à Educação. Dois exemplos são: o Simpósio Nacional de Educação em Astronomia (SNEA) e as reuniões da Sociedade Astronômica Brasileira (SAB). O ensino desse domínio também se apresenta em eventos com temas gerais ou relacionados a outras áreas, como o Simpósio Nacional de Ensino de Física (SNEF) e o Encontro Nacional de Pesquisa em Ensino de Ciências (ENPEC).

No que se refere, especificamente, à pesquisa relacionada ao ensino sobre as estrelas, também notamos grande deficiência, pois são poucos os trabalhos que tratam da Astrofísica Estelar na educação básica como tema principal, tanto no âmbito nacional quanto no internacional, como afirmam Langhi e Nardi (2012) e Lelliott e Rollnick (2010). A grande maioria dos trabalhos envolvem questões relacionadas ao sistema Sol-Terra-Lua ou às estações do ano (LANGHI; NARDI, 2012). Segundo Pasachoff (2002), até mesmo nas universidades é possível perceber esse fato.

De maneira geral, observamos grande defasagem no ensino da Astrofísica Estelar, em questões práticas e na produção de trabalhos de pesquisa. Os estudantes apresentam considerável deficiência no que diz respeito à compreensão dos aspectos fundamentais das estrelas (BAILEY, 2008; LELLIOTT; ROLLNICK, 2010).

\subsection{Astrofísica Estelar na educação básica}

Como acabamos de apontar, apesar da importância e da presença do tema da Astrofísica Estelar nos currículos educacionais, existe uma grande deficiência relativa a este no ensino básico. As propostas nem sempre são colocadas em prática, e os alunos finalizam essa etapa de sua formação com uma lacuna importante. 
De acordo com a Proposta Curricular do estado de São Paulo (2011) para a disciplina de Física na primeira série do Ensino Médio, é previsto como tema específico do quarto bimestre "As etapas da evolução estelar (formação, gigante vermelha, anã branca, supernova, buraco negro etc.)”. Entretanto, no material de apoio ao currículo do estado de São Paulo (2014), os itens mencionados não aparecem de maneira explícita, sendo ausente qualquer explicação sobre a formação, a evolução e o fim das estrelas e sobre os aspectos físicos envolvidos.

Também é possível observar nos PCN a proposta do ensino da Astrofísica Estelar na educação básica. Porém, é notório que o assunto é mencionado apenas como temática do Ensino Fundamental, uma vez que envolve aspectos mais elaborados da Física, indicados para o Ensino Médio:

Chega-se, então, à visão dinâmica da Terra no Universo. As idéias de Newton foram revolucionadas pelas idéias de Einstein, que deram origem a um novo modelo de Universo. Fenômenos como Buracos Negros, Quasares, Estrelas de Nêutrons, Gigantes Vermelhas, Anãs Brancas e outros fenômenos envolvendo a evolução das estrelas e do próprio Universo podem ser aprofundadas em leituras paradidáticas bem orientadas. (BRASIL, 1998)

Embora exista uma carência na pesquisa sobre o ensino da Astrofísica Estelar tanto no âmbito nacional quanto no internacional, há na literatura alguns trabalhos que envolvem o tema de formas diferentes. Alguns deles serão apresentados a seguir.

Bailey (2008) fez um levantamento sobre as concepções e as dificuldades dos estudantes a respeito da formação estelar. O estudo envolve alunos matriculados em uma disciplina de introdução à Astronomia em graduações não relacionadas a ciências e estudantes inscritos no ASTRO 101, um curso geral presente em todo o meio universitário estadunidense disponível na Internet. O autor nota uma lacuna importante na bagagem dos discentes quando trata de questões fundamentais do ciclo estelar, como a fusão nuclear, indicando que eles saem da escola com dificuldades notáveis no que se refere à astronomia.

Bailey (2009) também publicou outro artigo para investigar os conhecimentos prévios sobre formação e evolução estelar. O estudo envolve alunos que haviam iniciado o curso de graduação em áreas não relacionadas a ciências com a finalidade de avaliar os mencionados saberes. Apesar de estar presente nas propostas curriculares para o ensino básico, o ensino da Astrofísica Estelar muito pouco se apresenta em trabalhos de pesquisa em Educação, 
indicando deficiência na aplicação do tema na sala de aula. Os resultados mostram que os estudantes têm conhecimento prévio apreciável sobre as estrelas; no entanto, este é inconsistente ou incompleto quando comparado com a compreensão científica.

Isso pode ser verificado a partir da análise sobre a pergunta “O que é uma estrela?", feita aos alunos. Alguns estudantes acrescentaram mais de um fator na resposta, sendo a soma das porcentagens superior a 100\%. $80 \%$ dos estudantes definem as estrelas como gás ou poeira; 44\% afirmam que estão "queimando"; e 29\% relacionam-nas com "liberação de energia”. Apenas 10\% disseram que o Sol é uma estrela; $4 \%$ citaram a fusão nuclear; e 3\% alegaram não saber ou não responderam, conforme mencionado pela autora. Assumindo que a colocação correta seja que uma estrela é composta por gás e realiza fusão nuclear constantemente, apenas 2\% (9 em valores absolutos, em um total de 391 alunos) dos estudantes responderam de maneira satisfatória.

Agan (2004) realizou um trabalho em que foram analisados os conhecimentos de alunos do Ensino Médio e do primeiro ano de graduação sobre estrelas. Foi feita uma comparação entre estudantes do último ano do Ensino Médio (fourth-year high school) que já haviam realizado algum curso sobre Astronomia, alunos do primeiro ano do Ensino Médio (first-year high school) que não haviam feito nenhum curso nessa área e educandos de graduação sem instrução formal nesse setor. Os resultados indicam que os discentes que estudaram Astronomia na escola possuem conhecimentos específicos mais apurados sobre as estrelas, enquanto os demais sujeitos apontam, principalmente, características secundárias.

Pasachoff (2002) fornece uma rica discussão sobre o conteúdo de Astronomia que os estudantes deveriam aprender na escola. Esse trabalho também menciona a deficiência nos conhecimentos astronômicos que os alunos apresentam quando entram na faculdade. Grande parte dos estudantes não possui saberes corretos no que se refere às fases da Lua ou mesmo à causa das estações do ano, o que promove o debate sobre a inserção da Astronomia contemporânea, ou seja, dos assuntos ainda mais complexos na grade curricular, como estrelas, buracos negros e quasares. Pasachoff (2002) afirma ser a favor da inclusão desses fatores, uma vez que são os tópicos da Astronomia moderna e os objetivos dos estudos nos dias de hoje para a comunidade científica. Já as fases da Lua ou as estações do ano são temáticas fundamentais desse âmbito e não deveriam ser tratadas como obstáculo, mas sim como um estímulo para o aperfeiçoamento dessa ciência na Educação. 
Iachel (2011) avaliou os conhecimentos prévios de 125 alunos da 1. a série do Ensino Médio matriculados em três escolas da rede estadual de Bauru/São Paulo a partir de um questionário a respeito das estrelas e de seu ciclo evolutivo. Segundo o autor, os alunos apresentam dificuldades para descrever as características das estrelas. Em sua pesquisa, por exemplo, $76 \%$ dos estudantes não esboçaram qualquer tentativa de mostrar como é o funcionamento delas. Entre outras conclusões, o trabalho mostra que os discentes não possuem o hábito de observar a natureza mais detalhadamente.

Horvath (2013) propõe uma abordagem empírica para o ensino da Astrofísica Estelar no Ensino Médio de forma simples e objetiva. O autor afirma que um dos problemas enfrentados pelo ensino desse conteúdo é a necessidade de aparelhos cada vez mais sofisticados, o que distancia o tema das escolas. Tais fenômenos não são facilmente observáveis no céu noturno como outros conceitos mais básicos da Astronomia, tendo os alunos que simplesmente confiar nos dados apresentados. Segundo o autor, esse é um dos motivos que torna "as ciências naturais [...] cada vez menos naturais" (HORVATH, 2013).

O estudo da Astronomia pode proporcionar ao estudante aspectos importantes em seu desenvolvimento cognitivo, além de ser muito eficaz para aprimorar o conhecimento científico em um curto período do tempo (AGAN, 2004). Alunos que estudaram astronomia durante o estágio escolar desenvolveram de maneira mais efetiva a percepção sobre aspectos específicos relacionados às estrelas e à Física, o que parece bastante razoável, uma vez que foi perceptível na atividade que os discentes com conhecimentos prévios sobre Astrofísica Estelar tiveram mais facilidade no desenvolvimento do trabalho.

No entanto, as respostas dos estudantes de astronomia que participaram deste estudo foram especialmente impressionantes. Esses alunos usaram qualidades funcionais para a diferenciação de objetos astronômicos (produção de energia em estrelas) e regularmente expressaram uma profunda apreciação pelas escalas de distância. Uma ênfase na produção de energia nas estrelas e uma apreciação da escala são dois aspectos da astronomia que são fundamentais para a compreensão do cientista especialista sobre o assunto. (AGAN, 2004)

Segundo Iachel (2011), estudos realizados afirmam a importância em conhecer os conhecimentos prévios dos alunos a respeito da Astronomia para que os professores possam planejar suas aulas se apoiando nessas concepções. Assim, é possível enriquecer as discussões e os debates que visam o ensino dessa ciência. 
Como notamos anteriormente, a deficiência no ensino da Astrofísica Estelar vai além do Brasil, pois é possível perceber uma relação entre os conhecimentos prévios dos alunos daqui e de outros países. É comum o estudante pensar em Astronomia com uma visão limitada ao Sistema Solar, sem ter noção sobre as características e as propriedades das estrelas. (AGAN, 2004; BAILEY, 2009; IACHEL; LANGHI, 2008).

Segundo Furutani (2009), uma alternativa interessante para ensinar Astrofísica Estelar é construir modelos de estrelas de diferentes tamanhos. Se eles têm as devidas proporções, podem apresentar aos alunos as relações entre os diferentes tipos de estrelas em distintos estágios de evolução. Todavia, a construção de modelos parece um pouco limitada, pois os aspectos físicos e matemáticos envolvidos não são facilitados dessa forma, sendo importante a utilização de outros recursos para tal função, como esquemas gráficos, imagens ou animações.

Reinfeld e Hartman (2009) propuseram outra atividade sobre o ciclo estelar, feita com imagens de pessoas em diferentes fases da vida. $\mathrm{O}$ estudo mostra que essa pode ser uma boa estratégia para apresentar os variados estágios evolutivos das estrelas. Durante as aulas realizadas para esta pesquisa, procuramos utilizar exemplos semelhantes, os quais tiveram retorno positivo dos alunos.

Tendo em vista as dificuldades dos alunos com a Astrofísica Estelar e as possibilidades de trabalho expostas, adentramos na temática desta dissertação. Em seguida, discutimos como esse conteúdo é ou poderia ser apresentado no Ensino Médio. 


\section{ASTROFÍSICA ESTELAR NO ENSINO MÉDIO}

Apesar de a Astronomia não constituir, de forma efetiva, um tema de estudo na escola, quando falamos sobre ela, uma das coisas que logo vem à mente são as estrelas. É natural surgirem dúvidas como estas: o que são estrelas? Do que são feitas? Estrelas "nascem" e "morrem"?

A origem da explicação moderna da constituição e da vida das estrelas emergiu quando Fraunhöfer identificou as linhas espectrais do Sol, fator determinante para constatar que as demais estrelas eram "outros sóis". Ao repetir o procedimento realizado por Fraunhöfer nas estrelas, foi confirmada a semelhança de seus espectros com o espectro solar.

Basicamente, hoje pensamos que as estrelas são esferas gigantes compostas por gás. Sua temperatura é muito alta, e o combustível que as mantém é a fusão nuclear. A gravidade assume papel fundamental no ciclo de uma estrela, inclusive no que diz respeito ao tempo de existência e à forma que o astro terá no futuro. Todos esses conceitos foram estudados a fundo e confirmados no século 20, já que era preciso uma teoria consolidada da estrutura e da evolução estelar tal como formulada por Eddington, Hertzprung, Russell, Bethe e outros estudiosos.

Os fenômenos físicos que envolvem o ciclo estelar são importantes, pois as temperaturas mais altas que existem atualmente no universo, bastante próximas às do Big Bang, são as detectadas em explosões de Supernovas. O nível de calor dentro de uma estrela do tipo solar atinge várias dezenas de milhões de graus, é necessário para produzir a fusão do hidrogênio (HORVATH, 2008) e progride em estrelas de massas maiores.

Outro fator de grande importância associado às estrelas é seu papel na origem dos elementos químicos. Todo o hidrogênio presente no universo, possivelmente, formou-se logo após o Big Bang. Porém, a temperatura e a expansão do universo não permitiram que muitos elementos mais pesados, além do deutério, do hélio e do lítio, fossem formados. A principal fonte de produção destes são as estrelas, o que ocorre por meio da fusão nuclear em seu interior. Existe um consenso de que os átomos mais pesados do que o berílio se formam unicamente nas estrelas ao longo de suas vidas ou dos eventos explosivos que acontecem no final delas (HORVATH, 2013).

As estrelas estão entre os principais focos de estudos da Astronomia e das Ciências Espaciais, de maneira a contribuir para o avanço do conhecimento e da tecnologia. Entre 
outros benefícios já citados anteriormente, o ensino da Astrofísica/Astronomia Estelar se faz importante também na educação básica (MATEUS; SODRÉ, 2003).

Dada a importância do assunto, além de se tratar de algo que pode ser bastante atrativo e interessante para os alunos, o ensino sobre as estrelas poderia até ser um dos focos principais no Ensino Médio. Algumas temáticas devem ser destacadas, por exemplo: a origem, a vida e a morte das estrelas; o Diagrama $H R$; as diferenças entre os diversos tipos de estrelas conhecidos; os possíveis destinos para os quais as estrelas podem seguir; os buracos negros; as estrelas de nêutrons. Durante a discussão dos conteúdos, uma série muito importante de questões físicas deve ser apresentada e discutida como "insumo", e a Astrofísica Estelar pode, assim, agir como tema catalisador e integrador de conceitos de grande importância, como veremos a seguir.

\subsection{O ciclo estelar}

Assim como no caso da água, do carbono, do nitrogênio e de outros compostos essenciais para os seres vivos, existe o ciclo estelar (Figura 1): a estrela se origina a partir de uma nuvem primordial formada quase inteiramente por gás. Quando a estrela morre, o meio em que se apresenta é enriquecido com novos elementos mais pesados. Estes, por sua vez, poderão fazer parte de outra nuvem primordial, a qual formará novas estrelas. O Sol pertence a uma geração avançada de estrelas. O Sistema Solar é rico em carbono, silício, ferro e outros elementos resultantes desse ciclo (HORVATH, 2008). Realçamos a importância do conceito de vida e morte com a decorrente modificação das abundâncias químicas, o qual, de imediato, revela a perspectiva da finitude do Sol e relaciona cada etapa com características bem definidas.

Já postulamos que as estrelas são gigantes esferas gasosas muito quentes, que têm como combustível a fusão nuclear. A gravidade está presente desde o início da formação da estrela até a morte desta. Isso significa que a massa assume papel crucial nesse processo, inclusive no que diz respeito ao tempo de vida de um astro como esse: quanto maior a massa, menor o tempo que ele "viverá"; e quanto menor a massa, maior o tempo que ele brilhará. De qualquer modo, o período de vida de uma estrela está na ordem dos bilhões de anos, o que dificulta o estudo dela em tempo real. Apesar de não podermos observar essa evolução em nosso ciclo de vida, existe uma forma de classificar as estrelas e, assim, compreender de 
maneira mais clara como ocorre tal fenômeno: o diagrama de Hertzsprung-Russell (ou Diagrama $H R$, apenas).

Figura 1 - Ciclo interestelar

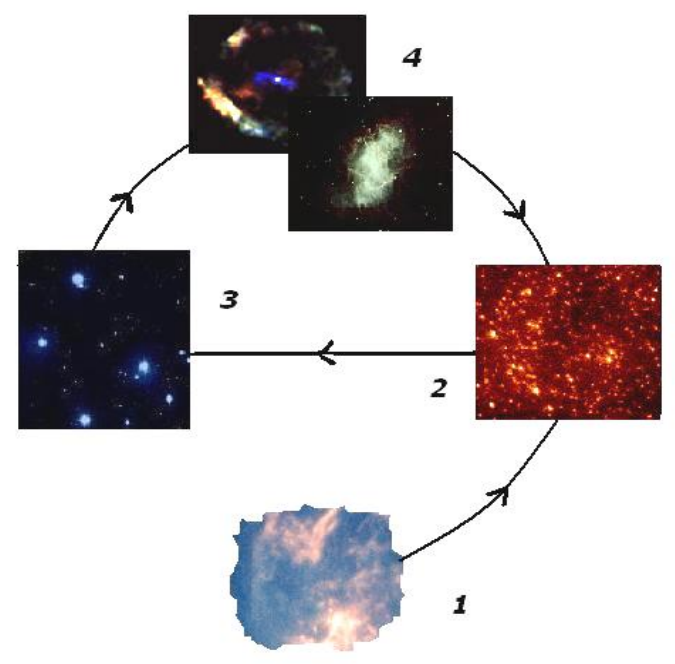

Legenda: 1) formação; 2) residência na Sequência Principal; 3) estágios avançados; 4) morte estelar, com a reinjeção de elementos químicos ao meio interestelar.

Fonte: HORVATH (2008).

\subsection{Diagrama de Hertzprung-Russell}

É incrivelmente alto o número de estrelas que compõem nossa galáxia (cerca de centenas de bilhões). Essas estrelas foram, e ainda são, objeto de estudo de muitos astrônomos no mundo todo, por isso hoje sabemos muito sobre elas. Todo esse esforço permitiu a criação de um diagrama que relaciona algumas características das estrelas e nos fornece as informações mais importantes sobre esses astros, chamado Diagrama de Hertzprung-Russell (Figura ${ }^{2}$ ), criado com o intuito classificatório que encontramos também na zoologia, na botânica etc., ou seja, com o propósito de ser um esquema fundamental que precisa ser explicado fisicamente por uma teoria abrangente. 
Figura 2 - Diagrama de Hertzprung-Russell

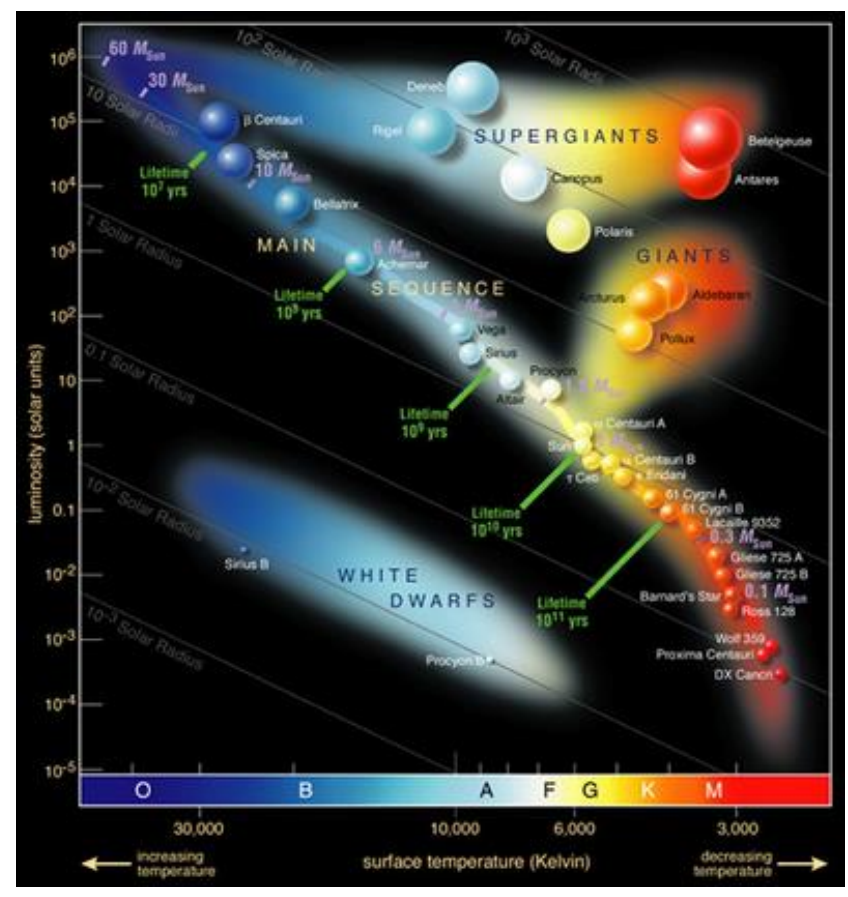

Fonte: Diagrama H-R (2018).

O Diagrama $H R$ foi elaborado pelo químico e astrônomo dinamarquês Ejnar Hertzsprung, em 1911, e pelo astrônomo estadunidense Henry Norris Russell, em 1913. Para desenhá-lo, é importante nos focarmos nas propriedades observadas das estrelas. A primeira destas é a cor apresentada. Imagine um objeto de metal em contato com o fogo. Haverá um momento em que o material se tornará incandescente, isto é, brilhará, assim como as antigas lâmpadas incandescentes, que, a partir do aquecimento de um filamento interno, iluminavam o ambiente.

Figura 3 - Metal incandescente

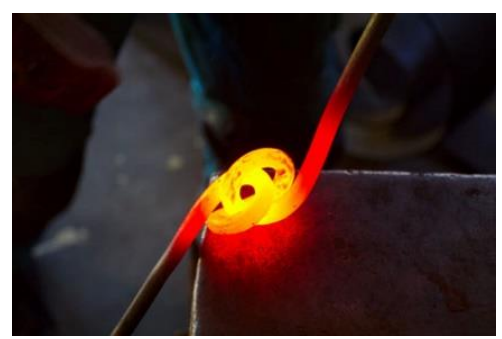

Fonte: Image (2017).
Figura 4 - Lâmpada incandescente

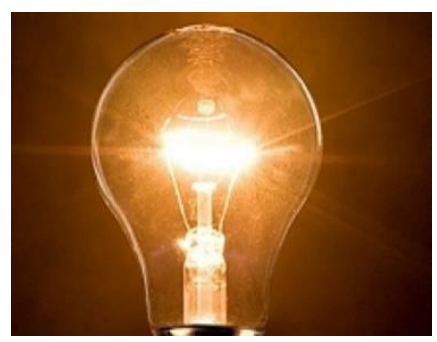

Fonte: Lampada (2017). 
Perceba que a cor dos objetos incandescentes ilustrados nas Figuras 3 e 4 está próxima do vermelho-alaranjado. Se continuarem expostos ao calor, ela mudará, aos poucos, do vermelho para o branco-amarelado: quanto mais tempo em contato com a fonte de calor, mais alta é a temperatura da peça metálica, e isso influencia em sua coloração. Podemos afirmar que a temperatura e a cor estão diretamente relacionadas.

Com as estrelas, isso funciona exatamente da mesma maneira: existem estrelas azuis, amarelas, vermelhas, cada uma com uma temperatura superficial específica. Isso pode ser mais bem compreendido ao observar o espectro eletromagnético:

Figura 5 - Espectro eletromagnético



Fonte: Características... (2017).

A Figura 5 mostra que as cores que compõem a luz visível possuem comprimento de onda e frequência específica. Para cada frequência, há uma temperatura correspondente. Ou seja, compreendendo o espectro e sabendo como a estrela emite radiação para cada comprimento de onda/frequência, basta identificar essa radiação para conhecermos sua temperatura superficial.

É importante mencionar aqui a radiação de corpo negro, ideia que surgiu em 1860 e impulsionou o estudo da astronomia na época. Usamos a denominação corpo negro para determinar um objeto que absorve perfeitamente a radiação de todos os comprimentos de onda. Quando está em equilíbrio termodinâmico, um corpo negro emite energia na mesma taxa que absorve, sendo essa emissão universal: os corpos negros de mesma temperatura 
liberam radiação no mesmo comprimento de onda. As estrelas são ótimos exemplos de corpos negros, suas cores, resultantes do espectro de emissão, indicam com precisão a temperatura correspondente.

O nome corpo negro é decorrente da absorção de toda a energia nele incidida. Teoricamente um corpo que não reflete luz é negro, mas os corpos negros também emitem energia, por isso podemos ver sua cor. Em se tratando de educação em Astronomia, essa parte merece cautela, pois pode aparecer confusa para os alunos.

Os estudos de radiação de corpo negro resultaram, entre outras coisas, na Lei de Stefan-Boltzmann. A partir da radiação coletada, é possível determinar o fluxo (quantidade de energia, ou radiação, emitida), que pode ser calculado da seguinte maneira:

$$
F=\sigma T^{4}
$$

Onde $\sigma=5,67 \times 10^{-8} \mathrm{~W} \mathrm{~m}^{-2} \mathrm{~K}^{-4}$.

A equação mostra que o fluxo $\mathrm{F}$ é diretamente proporcional à quarta potência da temperatura T. A Lei de Stefan-Boltzmann nos permite entender como o tamanho das estrelas varia no Diagrama HR. Podemos perceber isso a partir da determinação do fluxo:

$$
F=\frac{L}{4 \pi R^{2}}
$$

Unindo as equações 1 e 2, notamos a relação entre luminosidade, raio e temperatura. Uma linha vertical no Diagrama $H R$ mantém a temperatura constante e uma linha horizontal sustenta a luminosidade contínua.

$$
L=4 \pi R^{2} \sigma T^{4}
$$

Essa é precisamente a relação que precisávamos para construir o diagrama $H R$ : a luminosidade estelar é a quantidade colocada no eixo vertical. Assim, podemos dizer que o Diagrama $H R$ nos diz quanta potência $(L)$ emite a estrela que tem uma temperatura $T$, desde que a distribuição da luz seja a de um corpo negro. 


\subsection{Como as estrelas se formam}

Falar da formação de uma estrela já indica que estamos em presença de uma importante afirmação: a da finitude da vida estelar. Essa ideia em si não é, em absoluto, óbvia para os estudantes, tal como veremos depois neste estudo. Evidências recolhidas de forma moderna confirmaram uma hipótese do século 19 a respeito da presença de um gás no meio interestelar. A massa de gás interestelar, chamada nuvem interestelar ou nuvem molecular, é gigante e fria (com temperatura média de $15 \mathrm{~K}$ ), e sua densidade varia em torno de $10^{3} \mathrm{~cm}^{-3}$. Estudos progressivos permitiram a detecção de estrelas no interior das nuvens interestelares. Na Figura 6, observamos o conjunto de estrelas denominado Plêiades, com idade de, aproximadamente, 60 milhões de anos e com sua "nuvem-mãe". Em casos como esse, a aglomeração de estrelas jovens em uma nuvem molecular indica que o grupo surgiu em um mesmo evento a partir da nuvem interestelar.

Figura 6 - As Plêiades e sua "nuvem mãe"

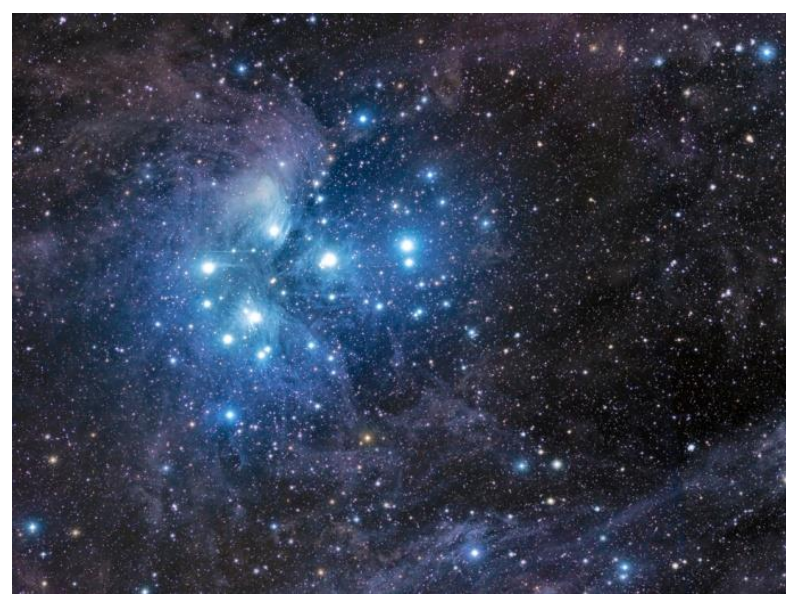

Fonte: Davis (2013).

Em baixas temperaturas, os átomos se unem formando moléculas $\left(\mathrm{H}_{2}\right.$, principalmente), fazendo com que a nuvem contenha moléculas. Geralmente, essas estruturas apresentam massas solares de, aproximadamente, $10^{6}$, e seu tamanho varia entre $10^{14}$ e $10^{15}$ $\mathrm{km}$.

As nuvens moleculares são difíceis de detectar, uma vez que são opacas. Por isso, não as enxergamos na luz visível, ou seja, não conseguimos vê-las! Sendo assim, é necessária 
a utilização de telescópios de rádio ou infravermelho em seu estudo. A Figura 7 é a Nebulosa Barnard 68, uma típica nuvem molecular.

O primeiro estágio da formação estelar se caracteriza por perturbações na nuvem original. As perturbações podem ser originadas, por exemplo, pela passagem de uma frente de Supernova, causando a compressão do gás interestelar. Assim, algumas porções da nuvem se tornam ligeiramente mais densas, exercendo atração gravitacional mais intensa sobre sua vizinhança. Esse fenômeno promove a formação de um ou mais “caroços” com maior concentração de massa, que, por sua vez, aumentam cada vez mais devido à gravidade.

Figura 7 - Nebulosa Barnard 68, uma densa nuvem molecular vista aqui como a ausência de luz no óptico

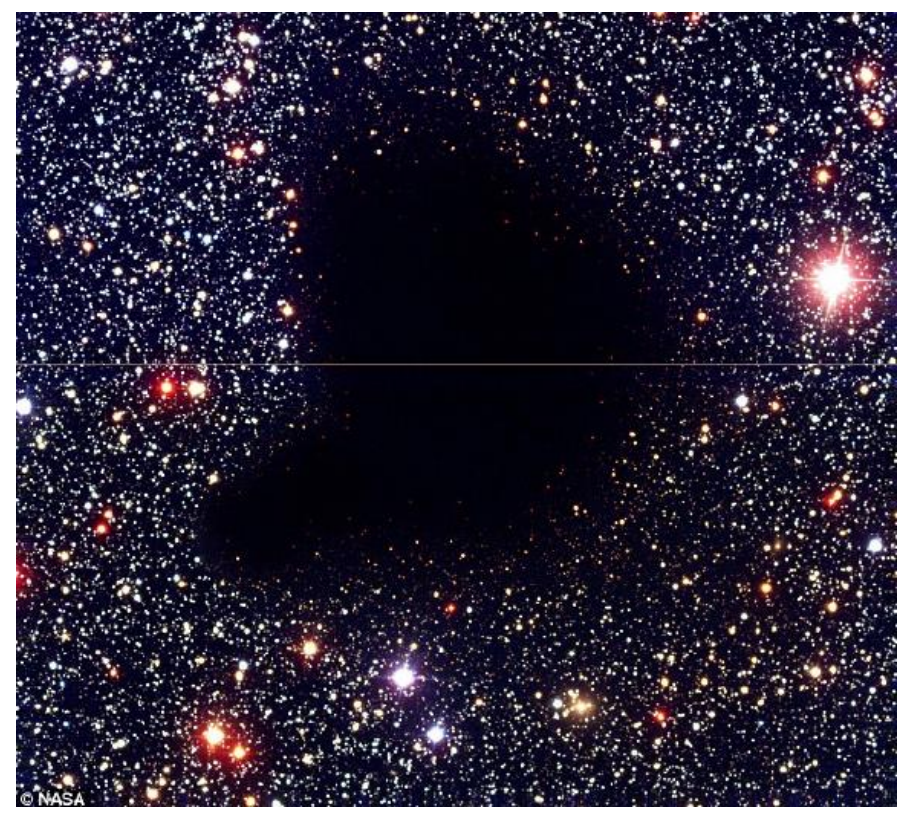

Fonte: Barnard 68 (2012).

Na fase seguinte, há a contração gravitacional e a consequente fragmentação do gás, formando um ou mais caroços, com maior concentração de massa. Estes, por sua vez, fragmentam-se em partes cada vez menores (a quantidade de núcleos é determinada de acordo com a massa da nuvem interestelar e a física das perturbações). Como consequência da contração, há conversão de energia gravitacional em energia térmica e radiação. 
Nesse momento, o gás está em uma fase bastante turbulenta e em total desequilíbrio. Isto é, a força da gravidade e a pressão interna não se encontram balanceadas. Conforme o gás se contrai, a temperatura e a pressão no interior do núcleo aumentam.

A nuvem molecular deve obedecer a determinadas condições para que haja o colapso e a formação dos fragmentos, que chamamos a Instabilidade de Jeans. Fisicamente, isso é bastante simples: a massa precisa ser grande o suficiente para promover uma força gravitacional superior às forças que impedem o colapso (pressão interna e campo magnético,

por exemplo). Essa quantidade de massa pode ser calculada balançando esses efeitos e é definida como massa de Jeans.

$$
M_{J}=\frac{3 k T R}{2 G m}
$$

Nessa equação, $k$ é uma constante, denominada constante de Boltzmann. $T$ é a temperatura. $R$ é o raio da nuvem. $G$ é a constante gravitacional. E $m$ é a massa da partícula de gás.

Essa equação foi desenvolvida pelo astrônomo James Jeans na década de 1940. Além da massa, pode ser determinado o chamado raio de Jeans, o qual mostra que existe um raio mínimo que a nuvem pode ter antes de se tornar instável e colapsar.

$$
R_{J}=\sqrt{\frac{15 k T}{4 \pi \rho G m}}
$$

Nessa fórmula, $\rho$ é a densidade da nuvem.

\subsection{A partilha de energia na nuvem: o Teorema do Virial}

As moléculas existentes na nuvem interagem entre si, existindo troca de energia e influência gravitacional. O Teorema do Virial foi elaborado no século XIX por um físico e matemático alemão chamado Rudolf Julius Emanuel Clausius (1822-1888). É um dos teoremas mais utilizados na Astrofísica e permite o estudo de sistemas que não estão em equilíbrio térmico, pois não depende da temperatura, mas sim das energias potencial e cinética associadas. A expressão virial deriva do latim (vis, viris), que significa força ou energia. Veremos seu uso no problema da formação estelar a seguir. 
No início do ciclo de vida de uma estrela, há um balanço de energias das moléculas do gás interestelar. O Teorema do Virial é estabelecido a partir de uma equação que relaciona a partilha da energia cinética total de um sistema e sua energia potencial da seguinte maneira:

$$
E_{c}=-\frac{1}{2} E_{p}
$$

Como dissemos anteriormente, nesse momento inicial, o gás está em total desequilíbrio. Isto é, a força da gravidade e a pressão interna se encontram desbalanceadas. Conforme o gás se contrai, a temperatura e a pressão no interior do núcleo aumentam, exercendo uma força contrária à da gravidade. Quando a massa de gás é grande o suficiente, a força da gravidade supera a pressão interna, e a nuvem colapsa, formando fragmentos cada vez menores. Essa grande quantidade de massa mínima para o colapso acontecer pode ser calculada (como visto na quarta equação apresentada) e é definida como massa de Jeans.

Após o colapso gravitacional, os fragmentos formados caracterizam a fase seguinte da formação estelar, a protoestrela. Nessa etapa, a temperatura interna é alta. Ainda que sua temperatura seja muito menor do que a de uma estrela da Sequência Principal, já consegue emitir muita radiação luminosa. O Teorema do Virial nos diz que rapidamente a nuvem em contração reparte sua energia, segundo a equação (6); e essa condição de equilíbrio virial deve se manter daí até a morte estelar (resulta quase impossível tirar o objeto do equilíbrio virial). Assim, a equação (6) é uma relação fundamental que vale para qualquer protoestrela ou estrela.

$$
P V=n R T
$$

Ainda assim, a protoestrela possui temperatura superficial menor e raio e luminosidade maiores comparados a uma estrela já formada na Sequência Principal. Diferentemente da nuvem primordial, a protoestrela já emite luz. Ou seja, a protoestrela é maior, mais fria e brilha mais que uma estrela por conta de seu raio ser muito maior.

Basicamente, a nuvem de gás, inicialmente gigante, vai se fragmentando cada vez mais até formar concentrações densas e quentes, e a protoestrela está no meio desse processo. Nesse momento, as forças do gás ainda estão em desequilíbrio e a protoestrela deve colapsar novamente formando fragmentos menores. 
As estrelas são esferas autogravitantes. Ou seja, desde sua formação, as moléculas do gás que a constituem sofrem a influência de sua própria gravidade. Na fase da protoestrela, o gás já adquiriu densidade e energia significativas. A conservação do momento linear, então, força o gás a assumir a forma de disco, e a protoestrela começa a girar, tornando-se algo semelhante à Figura 8. Como podemos notar, parte do material do disco é ejetado perpendicularmente para fora da estrutura.

Figura 8 - Reconstrução artística de uma protoestrela no meio do torus (disco grosso) de acreção, com os jatos protoestelares na perpendicular

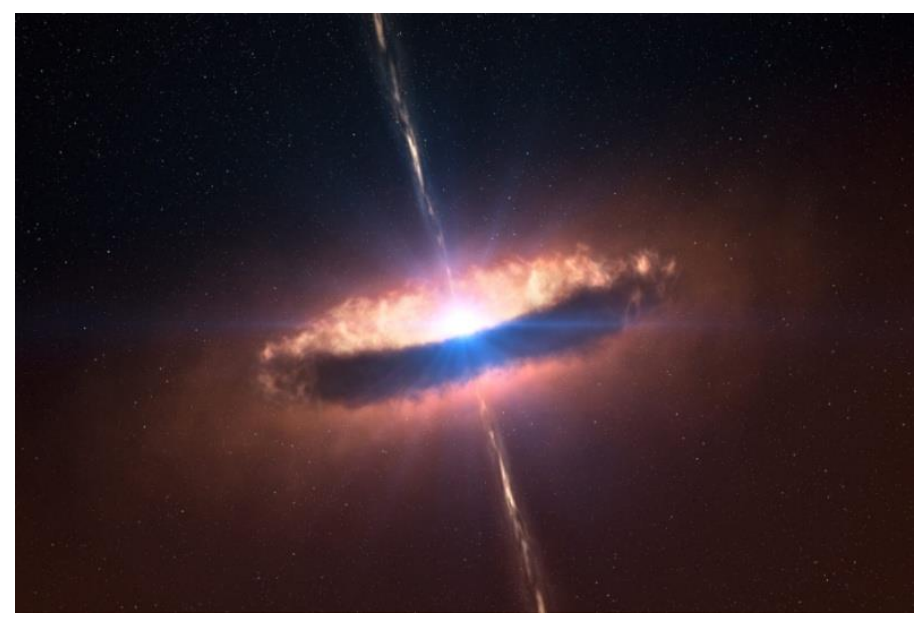

Fonte: Eso-L (2016).

Quando a protoestrela atinge determinada temperatura específica, inicia-se o processo de fusão nuclear dos átomos de hidrogênio: os núcleos de dois átomos se unem formando um novo núcleo mais pesado quando as energias cinéticas (relacionadas à temperatura mencionada) conseguem superar a repulsão elétrica de Coulomb. Para uma estrela do tipo do Sol, a temperatura necessária para que haja a fusão nuclear é de 10 milhões Kelvin, mas isso varia de acordo com a densidade da protoestrela:

$$
T \sim c \rho^{1 / 3}
$$

Nessa equação, $\rho$ é a densidade e $c$ é uma constante estimada como

$$
c=\frac{81 k^{3}}{32 \pi G^{3}}
$$


É importante destacar que existe um limite de massa mínimo para a formação estelar. A protoestrela deve ter, no mínimo, 0,08 massas solares (caso contrário, a temperatura é muito baixa para a fusão começar) e, no máximo, por volta de 100 massas solares (peso com o qual a estrutura estelar fica instável).

\subsection{Equilíbrio Hidrostático}

Quase simultaneamente ao início do processo de fusão nuclear, a estrela entra em equilíbrio hidrostático. Isto é, o campo gravitacional e o gradiente de pressão encontram-se estáveis, e a estrela para de colapsar.

$$
\frac{\Delta P}{\Delta R}=-\frac{G m}{r^{2}} \rho
$$

Essa forma é mais simples, com incrementos discretos, em vez das derivadas, mais adequados para as aulas. Podemos "ler" a equação (10) assim: quando "andamos para fora" da estrela, o decremento da pressão $\Delta P$, conforme incrementarmos o raio $\Delta R$, é a força (variação da pressão) que resulta localmente igual à força gravitacional exercida pelo fluido que está do lado direito.

\subsection{Uma proposta de ensino}

A ideia da exposição dos alunos aos conteúdos anteriores, e as consequências destes para as estruturas que chamamos de estrelas, para suas vidas e para seus finais (Figura 1) levou-nos a desenhar uma atividade didática para conferir até que ponto a temática poderia ser compreendida. A atividade aconteceu na Escola Estadual Prof. Gabriel Ortiz, uma instituição pública localizada na Zona Leste da cidade de São Paulo. Foram realizadas 2 aulas duplas (em 2 dias) expositivas, totalizando 4 aulas de 50 minutos cada, em 5 turmas da $2^{\text {a }}$ série do Ensino Médio do período noturno. Para o estudo, foi analisado o desenvolvimento de 69 alunos no decorrer das aulas, o qual constitui uma amostra significativa para efeitos educacionais.

A aula se baseou em uma apresentação de slides enriquecida com imagens, esquemas, animações e vídeos sobre o tema. Também foram feitas analogias com a finalidade de auxiliar no entendimento dos alunos. No início da aplicação, foi solicitado aos estudantes que respondessem ao questionário inicial (QI), representado no Quadro 1, antes de qualquer explicação sobre o tema, a fim de avaliar o conhecimento prévio dos estudantes. 
Após a aplicação do QI iniciou-se a apresentação e a explicação dos temas, conforme mostra o esquema a seguir:

Galáxias/distâncias $\rightarrow$ Céu estrelado $\rightarrow$ Constelações $\rightarrow$ Magnitude $\rightarrow$ Fluxo $\rightarrow$

Cor e temperatura $\rightarrow$ Radiação $\rightarrow$ Diagrama $H R \rightarrow$ Nuvem molecular $\rightarrow$ Teorema do Virial $\rightarrow$ Gravidade e pressão $\rightarrow$ Fusão Nuclear $\rightarrow$ Produção de energia $\rightarrow$ Equilíbrio Hidrostático $\rightarrow$ Evolução estelar $\rightarrow$ Gigante Vermelha $\rightarrow$ Nebulosa Planetária $\rightarrow$ Anã Branca $\rightarrow$ Explosão de Supernova $\rightarrow$ Buraco Negro/Estrela de Nêutrons.

Procuramos destacar os tópicos principais relacionados ao tema. Também buscamos estabelecer alguma relação com os conteúdos de Física do Ensino Médio, como luz e ondas, gravitação e produção de energia.

Nas duas primeiras aulas, os alunos tiveram uma introdução sobre a Astronomia, na qual foram discutidos os conteúdos sobre as galáxias e as distâncias astronômicas, o céu estrelado e as constelações. Em seguida, iniciamos o debate sobre as ondas eletromagnéticas, tratando da magnitude e do fluxo. Posteriormente, foi explicada a relação entre cor e temperatura e radiação para que o Diagrama $H R$ fosse apresentado aos alunos. Aproximandose o final da aula dupla, começamos a discorrer sobre a questão da formação. Apresentamos aos alunos o conceito de Nuvem Molecular e o Teorema do Virial e introduzimos o assunto da gravidade e da pressão.

É importante destacar que as aulas se desenvolveram de maneira que os alunos pudessem participar ativamente com perguntas e comentários, os quais foram utilizados como material para análise posterior. Os áudios das aulas foram gravados também para avaliação posterior do trabalho. 
Quadro 1 - Questionário Inicial (QI) respondido pelos alunos no início da atividade

\section{QI}

1. Desenhe uma estrela real.

2. Coloque um nome.

3. Do que é feita essa estrela?

4. Ela é quente ou fria?

5. Qual é a cor da estrela?

6. Quantos anos ela tem?

7. Qual é o tamanho da estrela (comparado ao da Terra)?

8. Ela emite algo que você conseguiria sentir, mesmo estando distante dela?

9. Você pode observar essa estrela por muitos anos sem perceber qualquer mudança. Como você acha que ela se mantém dessa forma?

10. Ela sempre foi assim ou era diferente quando se formou?

11. Ela vai ficar assim para sempre? Em caso negativo, o que vai acontecer com ela depois?

Fonte: Elaborado pela pesquisadora.

O conteúdo inicial do segundo e último dia da atividade foi a fusão nucelar e a produção dos elementos químicos no núcleo estelar e na produção de energia. Em seguida, tratamos do Equilíbrio Hidrostático e da evolução estelar, quando mencionamos o conceito de Gigante Vermelha. Após esse tópico, os alunos estudaram a "morte" das estrelas menos massivas, nas quais há formação de uma Anã Branca e de uma Nebulosa Planetária, e das estrelas mais massivas, abordando as explosões de Supernovas e a formação de um Buraco Negro ou uma Estrela de Nêutrons. 
Ao final da atividade, foi solicitado aos alunos que respondessem ao questionário final (QF). Este é semelhante ao QI, mas tem algumas alterações que levaram em conta o desenvolvimento das aulas.

Quadro 2 - Questionário Final (QF) respondido pelos alunos no final da atividade

\section{QF}

1. Desenhe uma estrela real.

2. Coloque um nome.

3. Do que é feita essa estrela?

4. Qual sua temperatura?

5. Qual é a cor da estrela?

6. Quantos anos ela tem?

7. Qual é o tamanho da estrela (comparado ao da Terra)?

8. Qual é o combustível dessa estrela?

9. Você pode observar essa estrela por muitos anos sem perceber qualquer mudança. Como você acha que ela se mantém dessa forma?

10. O que é luz e qual sua importância para as estrelas?

11. A estrela vai ficar assim para sempre? Em caso negativo, o que vai acontecer com ela depois?

12. Qual o papel da gravidade na formação e na evolução das estrelas?

13. Qual a relação entre as estrelas e os elementos químicos?

Fonte: Elaborado pela pesquisadora. 


\section{METODOLOGIA DE PESQUISA}

São apresentadas em seguida ferramentas utilizadas para construir este estudo. Descrevemos o roteiro utilizado para compor a atividade. Além disso, indicamos os objetivos da atividade proposta e apresentamos o referencial usado para embasar a análise de dados.

\subsection{Método de aplicação}

Um sumário essencial para executar a atividade pode seguir o roteiro relatado abaixo. Logo no início da atividade, o professor pode solicitar aos alunos que respondam ao QI sem apresentar qualquer conceito ou introdução ao que será apresentado. Após essa etapa, o professor pode iniciar a explicação do conteúdo conforme informado na seção 2.6. É importante que o docente tenha de maneira bastante clara as definições conceituais, as perguntas a serem feitas e as possíveis respostas dos alunos.

Uma estrela pode ser definida, de maneira geral, como uma grande estrutura relativamente esférica composta por gás, na qual alguns fenômenos físicos, como a gravidade, são extremamente importantes em todos os seus estágios de desenvolvimento. São listados a seguir alguns pontos que devem ser explicados aos discentes:

- As estrelas possuem evolução temporal quase estática: não é possível, em nosso tempo de vida, perceber alguma mudança significativa nelas.

- O papel da massa é extremamente significativo e determinante e deve ser destacado depois de ser estabelecida a importância da gravitação na evolução estrelar.

- A fusão nuclear é o combustível das estrelas.

- Os elementos químicos são produzidos a partir da fusão nuclear nas estrelas.

- O tamanho (raio) das estrelas pode variar bastante; porém, isso não significa, por exemplo, que uma estrela com raio maior possua mais massa.

Ao afinal da aula expositiva, o professor pode solicitar aos discentes que respondam ao QF. A aplicação do método consiste em pedir aos alunos que, a partir de perguntas, apresentem seus conhecimentos prévios após a explicação a respeito das estrelas. Em seguida, deve ser realizada uma análise dos trabalhos dos alunos, na qual seja possível perceber suas dificuldades iniciais e sua evolução com a aplicação da atividade. 


\subsection{Tipo de pesquisa}

Foi realizada na pesquisa uma abordagem metodológica qualitativa, atrelada a um estudo de caso para análise dos resultados coletados. De acordo com Lüdke e André (1986, p. 11),

a pesquisa qualitativa tem o ambiente natural como sua fonte direta de dados e o pesquisador como seu principal instrumento. Segundo os dois autores, a pesquisa qualitativa supõe o contato direto e prolongado do pesquisador com o ambiente e a situação que está sendo investigada, via de regra através do trabalho intensivo de campo. Por exemplo, se a questão que está sendo estudada é a da indisciplina escolar, o pesquisador procurará presenciar o maior número de situações em que esta se manifeste, o que vai exigir em contato direto e constante com o dia-a-dia escolar.

Lüdke e André (1986) apontam que os estudos de caso:

1. visam à descoberta;

2. enfatizam a "interpretação em contexto";

3. buscam retratar a realidade de forma completa e profunda;

4. usam uma variedade de fontes de informação;

5. revelam a experiência vicária e permitem generalizações naturalistas;

6. procuram representar os diferentes e, às vezes, conflitantes pontos de vista presentes em uma situação social;

7. utilizam, em seus registros, uma linguagem e uma forma mais acessível do que os outros relatórios de pesquisa.

Considerando o tipo de pesquisa adotado, passamos a discutir o problema do estudo.

Também ressaltamos na seção seguinte os objetivos deste trabalho.

\subsection{O problema}

O foco desta pesquisa parte de alguns objetivos. Um deles é entender se o uso de Astrofísica Estelar em aulas de Física é adequado. Buscamos também encontrar a melhor forma de elaborar, aplicar e estudar uma proposta direcionada para o ensino da Astrofísica Estelar por meio das aulas de Física do Ensino Médio. Tencionamos identificar uma programação de aula sobre Astrofísica Estelar para o Ensino Médio e 
colocar em evidência a evolução conceitual desenvolvida pelos alunos com a Astrofísica Estelar. Ademais, temos o intuito de analisar a aprendizagem dos alunos com relação ao programa proposto e aplicado.

Tendo em vista esses propósitos, surgiram estas hipóteses inicias:

1. O estudo da Astrofísica Estelar pode ser facilitado quando trabalhado em conjunto com a disciplina de Física.

2. Aspectos da Astrofísica Estelar são importantes para o desenvolvimento cognitivo do aluno, além de caminharem em conjunto com os temas da Física do Ensino Médio.

3. O aprendizado da Astrofísica Estelar pode contribuir para o desenvolvimento da visão crítica e do olhar científico do aluno.

A partir disso, emergiram alguns questionamentos. A proposta elaborada, aplicada e estudada pode ser legitimada como ensino de Astrofísica Estelar no Ensino Médio? Quais as evidências de aprendizagem e evolução conceitual verificadas nos estudantes em relação aos conteúdos abordados? Quais reflexões sobre o uso de tal metodologia são reveladas?

Foram utilizadas algumas fontes de dados no decorrer da atividade para que fosse possível avaliar as informações e atingir os objetivos propostos. São elas: questionários, gravação dos áudios das aulas e anotações do pesquisador. Todas as fontes de dados são mostradas a seguir.

\subsection{Fontes de dados}

A atividade se desenvolveu com a aplicação de dois questionários. O Questionário Inicial (QI), como relatado, foi realizado antes da apresentação dos conceitos abordados na atividade, com a intenção de identificar os conhecimentos prévios dos alunos. Já o Questionário Final (QF) foi aplicado no fim, após as explicações sobre o tema, com o objetivo de avaliar a evolução dos alunos a partir da proposta.

Além disso, foram gravados os áudios das aulas, a fim de captar as falas dos alunos, as dúvidas e os comentários durante a atividade. Solicitamos para a instituição de ensino permissão para a gravação. 
No decorrer da atividade, foram feitas notas de falas dos alunos sobre a aula. Estas foram verificadas posteriormente e auxiliaram no processo de análise.

\subsection{Referencial Teórico para análise dos dados}

Em relação à análise de dados, recorremos à Análise de Conteúdo de Bardin (2011). Nela, é utilizada a identificação de indicadores nos resultados apresentados pelos estudantes, possibilitando a realização de deduções lógicas ou inferências de conhecimento, a fim de verificar se os dados satisfizeram os propósitos do trabalho.

A análise de conteúdo pode ser compreendida como a associação de técnicas de análise das falas dos estudantes. Bardin (2011) determina três etapas para a investigação dos dados: "As diferentes fases da análise de conteúdo, tal como o inquérito sociológico ou a experimentação, organizam-se em torno de três polos cronológicos: 1) a pré-análise; 2) a exploração; 3) o tratamento dos resultados, a inferência e a interpretação". Primeiramente, temos a organização do processo de análise. Nesse momento, determinamos, a partir do projeto a ser desenvolvido, a problemática, a escolha dos materiais a serem estudados, a hipótese, os objetivos etc. A fase seguinte se refere ao reconhecimento do material, que leva em conta a codificação das falas, a enumeração, entre outros aspectos. Na última etapa, há o tratamento dos resultados, a seleção dos dados obtidos, as interpretações e a realização de inferências. 


\section{ANÁLISE DE DADOS E DISCUSSÃo}

Neste capítulo, analisamos os dados provenientes da atividade desenvolvida com a mencionada turma de segundo ano do Ensino Médio. As seções estão organizadas a partir das perguntas propostas no Questionário Inicial e no Final.

\subsection{Análise do grupo como um todo}

A seguir serão abordadas as questões com os gráficos e os quadros produzidos a partir das respostas dos alunos nos questionários final e inicial. Em relação aos gráficos, o eixo vertical representa a quantidade de alunos e o horizontal indica as categorias de respostas.

\subsubsection{Desenho de uma estrela real}

Na Questão 1, em que se pede para desenhar uma estrela real, procuramos verificar qual a concepção dos alunos com relação ao formato de uma estrela. As Figuras 9 e 10 e o Quadro 3 mostram as categorias de respostas dadas pelos alunos no Questionário Inicial (QI) e no Questionário Final (QF).

Figura 9 - Gráfico das categorias de respostas para a Questão 1 do QI

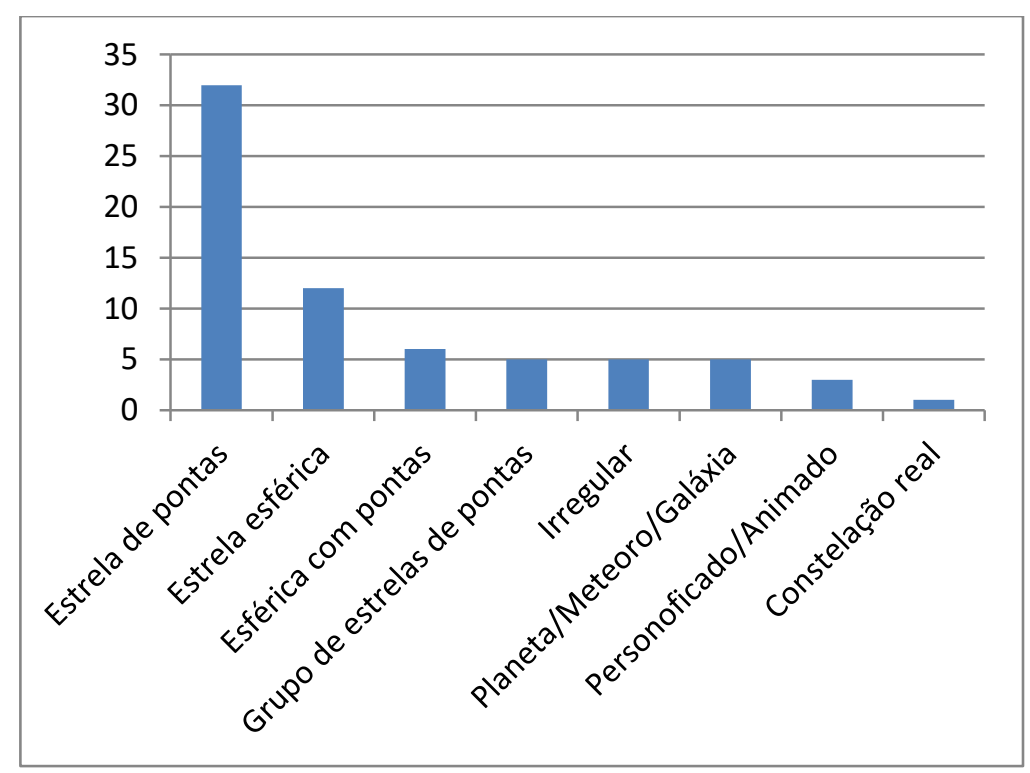

Fonte: Elaborado pela pesquisadora. 
Figura 10 - Gráfico das categorias de respostas para a Questão 1 do QF

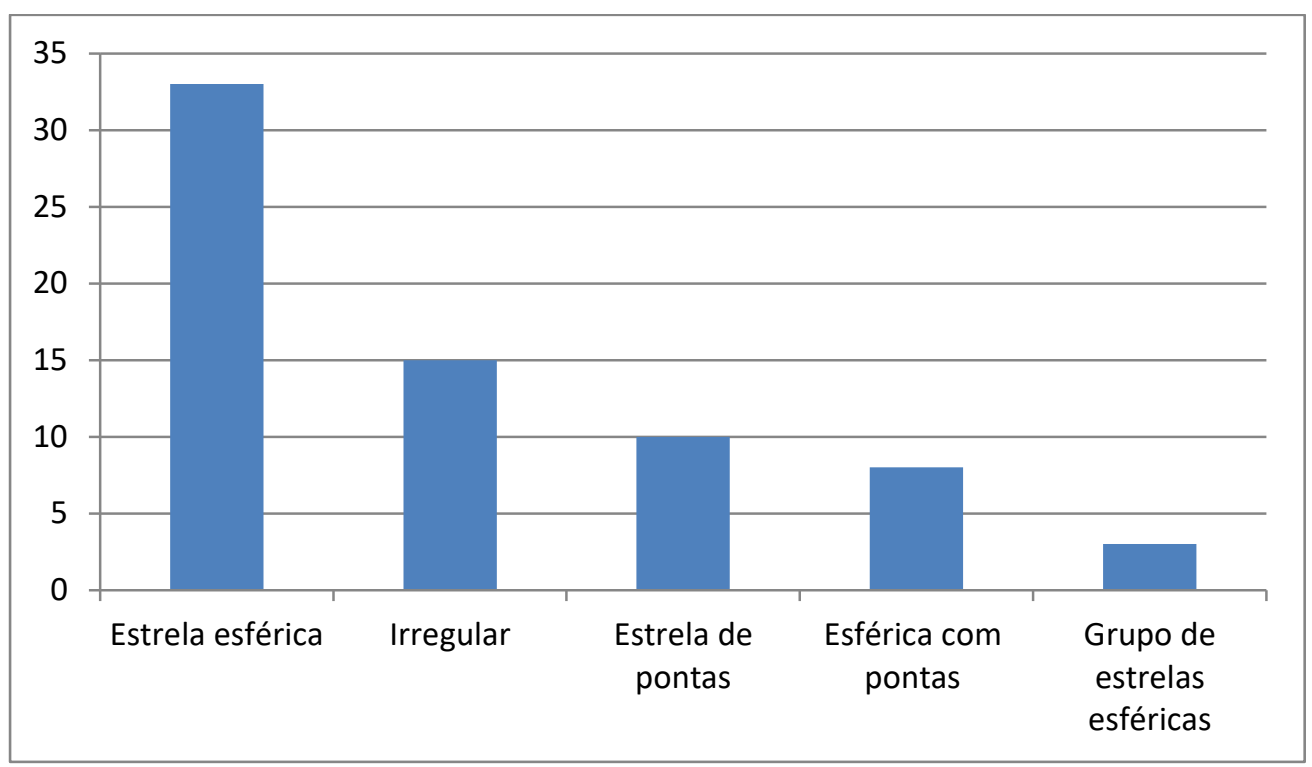

Fonte: Elaborado pela pesquisadora.

Quadro 3 - Relação entre as categorias de respostas para a Questão 1 do QI e do QF

\begin{tabular}{|l|c|c|l|c|c|}
\hline \multicolumn{7}{|c|}{ QI } & & \multicolumn{2}{c|}{ QF } \\
\hline Categoria de resposta & $\mathbf{N}$ & $\mathbf{\%}$ & Categoria de resposta & $\mathbf{~ N}$ & \% \\
\hline Estrela de pontas & 32 & 46,4 & Estrela esférica & 41 & 59,4 \\
\hline Estrela esférica & 18 & 26,1 & Irregular & 15 & 21,7 \\
\hline Grupo de estrelas & 5 & 7,2 & Estrela de pontas & 10 & 14,5 \\
\hline Irregular & 5 & 7,2 & Grupo de estrelas & 3 & 4,3 \\
\hline Planeta/Meteoro/Galáxia & 5 & 7,2 & & & \\
\hline Personificado/Animado & 3 & 4,3 & & & \\
\hline Constelação real & 1 & 1,4 & & & \\
\hline
\end{tabular}

Fonte: Elaborado pela pesquisadora.

Inicialmente, a maior parte dos estudantes (32 alunos, que correspondem a 46\%) representou a estrela com o desenho clássico de uma estrela de 5 pontas. Exemplos desses desenhos podem ser vistos a seguir. Também no Questionário Inicial, alguns estudantes desenharam outros objetos para representar uma estrela, como planetas, meteoros e galáxias $(7 \%)$. 
Figura 11 - Desenho da estrela de cinco pontas feito pelo Aluno 1

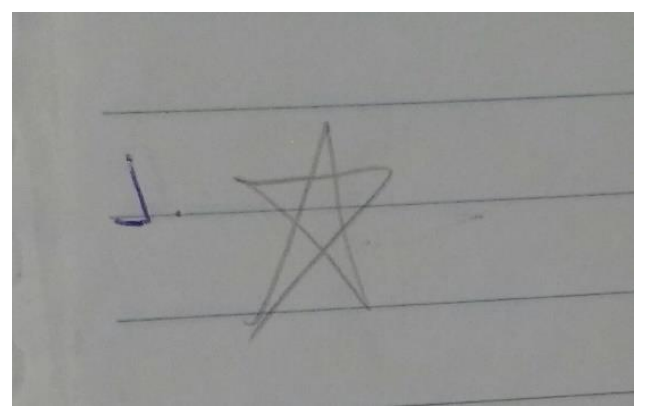

Fonte: Arquivo da pesquisadora

Figura 13 - Desenho de galáxia feito pelo Aluno 3

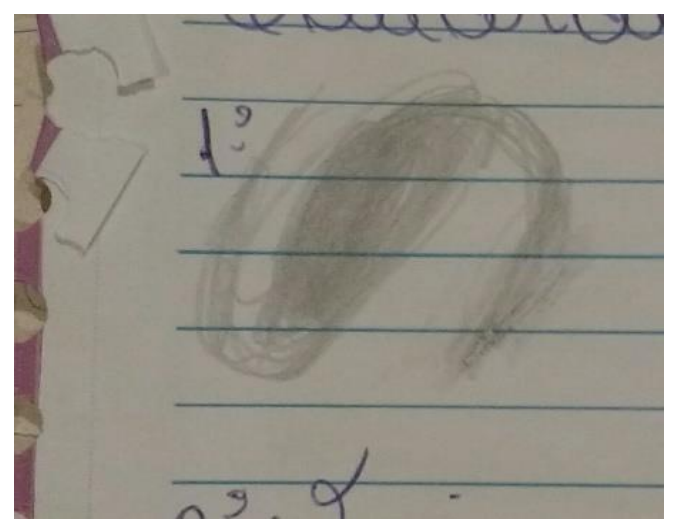

Fonte: Arquivo da pesquisadora
Figura 12 - Desenho da estrela de cinco pontas feito pelo Aluno 2

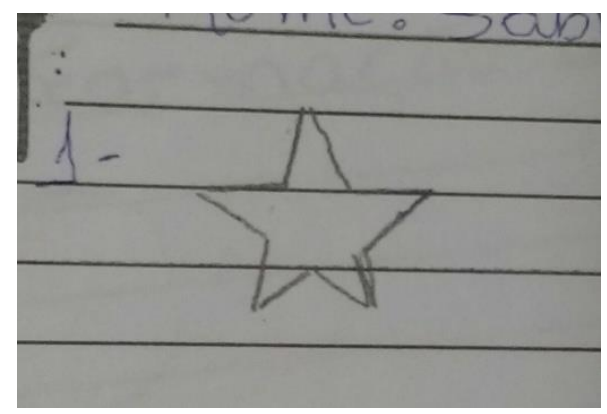

Fonte: Arquivo da pesquisadora

Figura 14 - Desenho de meteoro feito pelo Aluno 4

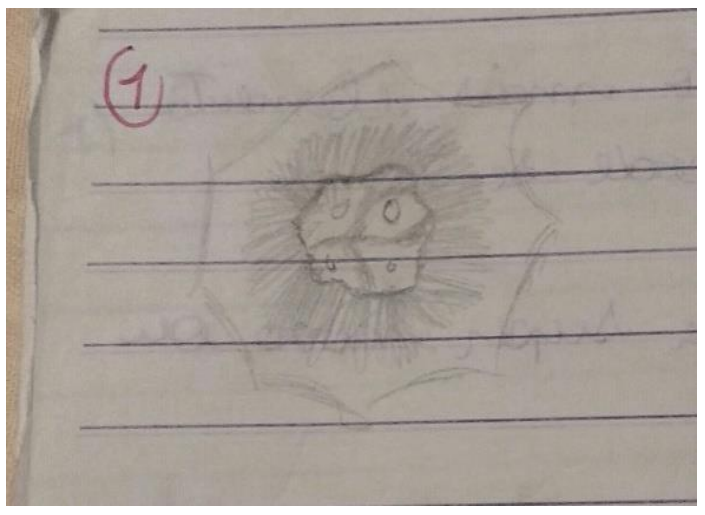

Fonte: Arquivo da pesquisadora

Apesar de haver um equívoco, esses objetos estão relacionados com a Astronomia, mas indicam confusão e falta de clareza por parte dos alunos a respeito do tema. Já no Questionário Final, a grande maioria desenhou uma estrela esférica (59\%), como demonstrado nas Figuras 15 e 16. 
Figura 15 - Desenho de estrela esférica feito pelo Aluno 1



Fonte: Arquivo da pesquisadora.
Figura 16 - Desenho de estrela esférica feito pelo Aluno 2

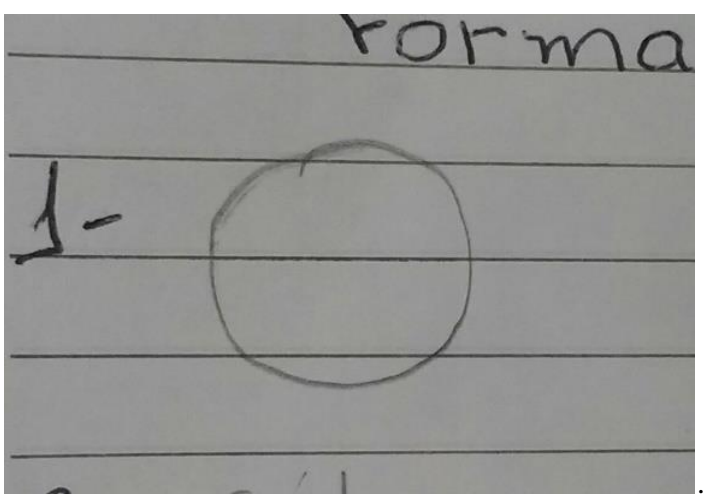

Fonte: Arquivo da pesquisadora.

A quantidade de respostas diferentes foi menor e mais homogênea no questionário final. Isso demonstra uma evolução positiva nas respostas.

\subsubsection{O nome das estrelas}

A segunda questão se refere ao nome da estrela. O objetivo era saber se os alunos possuem algum conhecimento prévio sobre os nomes das estrelas reais, dado que é irrelevante fisicamente, mas tem importância contextual e cultural.

Figura 17 - Gráfico das categorias de respostas para a Questão 2 do QI

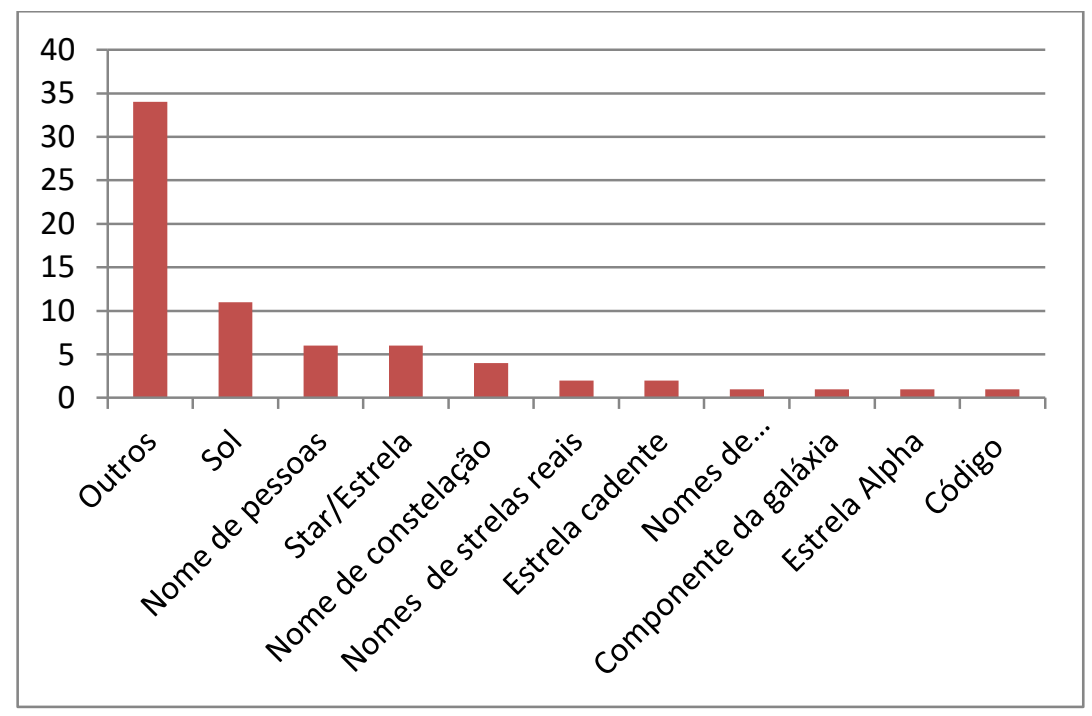

Fonte: Arquivo da pesquisadora. 
No QI, as categorias de respostas de maior frequência foram "Nomes inventados" (48\%) e "Sol" (16\%). Também houve "Nomes de pessoas" (9\%) e "Star/Estrela" (9\%).

Com relação ao QF, os dois tipos de respostas que aparecem em maior número são os mesmos do QI: "Nomes inventados" (39\%) e "Sol” (26\%). Após essas duas categorias, temos "Nomes de estrelas reais" (10\%), demonstrando que houve evolução positiva dos alunos em relação a esse tema, já que essa designação não se encontra no QI.

Figura 18 - Gráfico das categorias de respostas para a Questão 2 do QF



Fonte: Elaborado pela pesquisadora. 
Quadro 4 - Relação entre as categorias de respostas para a Questão 2 do QI e do QF

\begin{tabular}{|l|c|c|l|c|c|}
\hline \multicolumn{7}{|c|}{ QI } & \multicolumn{1}{c|}{ QF } \\
\hline \multicolumn{1}{|c|}{ Categoria de resposta } & N & \% & \multicolumn{1}{c|}{ Categoria de resposta } & N & \% \\
\hline Nomes inventados & 33 & 47,8 & Nomes inventados & 27 & 39,1 \\
\hline Sol & 11 & 15,9 & Sol & 18 & 26,1 \\
\hline Nome de pessoas & 6 & 8,7 & Nomes de estrelas reais & 7 & 10,1 \\
\hline Star/Estrela & 6 & 8,7 & Nome de pessoas & 5 & 7,2 \\
\hline Nome de constelação & 4 & 5,8 & Star/Estrela & 4 & 5,8 \\
\hline Nomes de estrelas reais & 2 & 2,9 & Nome de Planeta/Galáxia/etc. & 1 & 1,4 \\
\hline Estrela cadente & 2 & 2,9 & Estrela cadente & 1 & 1,4 \\
\hline Nomes de Planeta/Galáxia/etc. & 1 & 1,4 & Esfera de hidrogênio & 1 & 1,4 \\
\hline Componente da galáxia & 1 & 1,4 & Gigante azul & 1 & 1,4 \\
\hline Estrela de Davi & 1 & 1,4 & Código & 1 & 1,4 \\
\hline Estrela Alpha & 1 & 1,4 & Lua & 1 & 1,4 \\
\hline Código & 1 & 1,4 & Nome de constelação & 1 & 1,4 \\
\hline & & & Buraco negro & 1 & 1,4 \\
\hline
\end{tabular}

Fonte: Elaborado pela pesquisadora.

Notamos também no QF a presença das categorias "Esfera de Hidrogênio" $(1,4 \%)$ e “Gigante azul” $(1,4 \%)$, nomes que indicam aquisição de conhecimento por parte dos alunos em relação à Astrofísica Estelar. Apesar de não haver mudança significativa no resultado geral, alguns alunos mostraram resultados positivos, como exposto a seguir:

Aluno 1 - QI: A estrela se chama Lança do destino.

Aluno 1-QF: O nome da estrela é Sol.

Aluno 2-QI: Darkness.

Aluno 2-QF: O nome da estrela é Sirius.

\subsubsection{Composição das estrelas}

A Questão 3 teve a finalidade de verificar a concepção dos alunos a respeito da composição das estrelas. As categorias de respostas podem ser observadas nas Figuras 19 e 20 e no Quadro 5. 
Figura 19 - Gráfico das categorias de respostas para a Questão 3 do QI

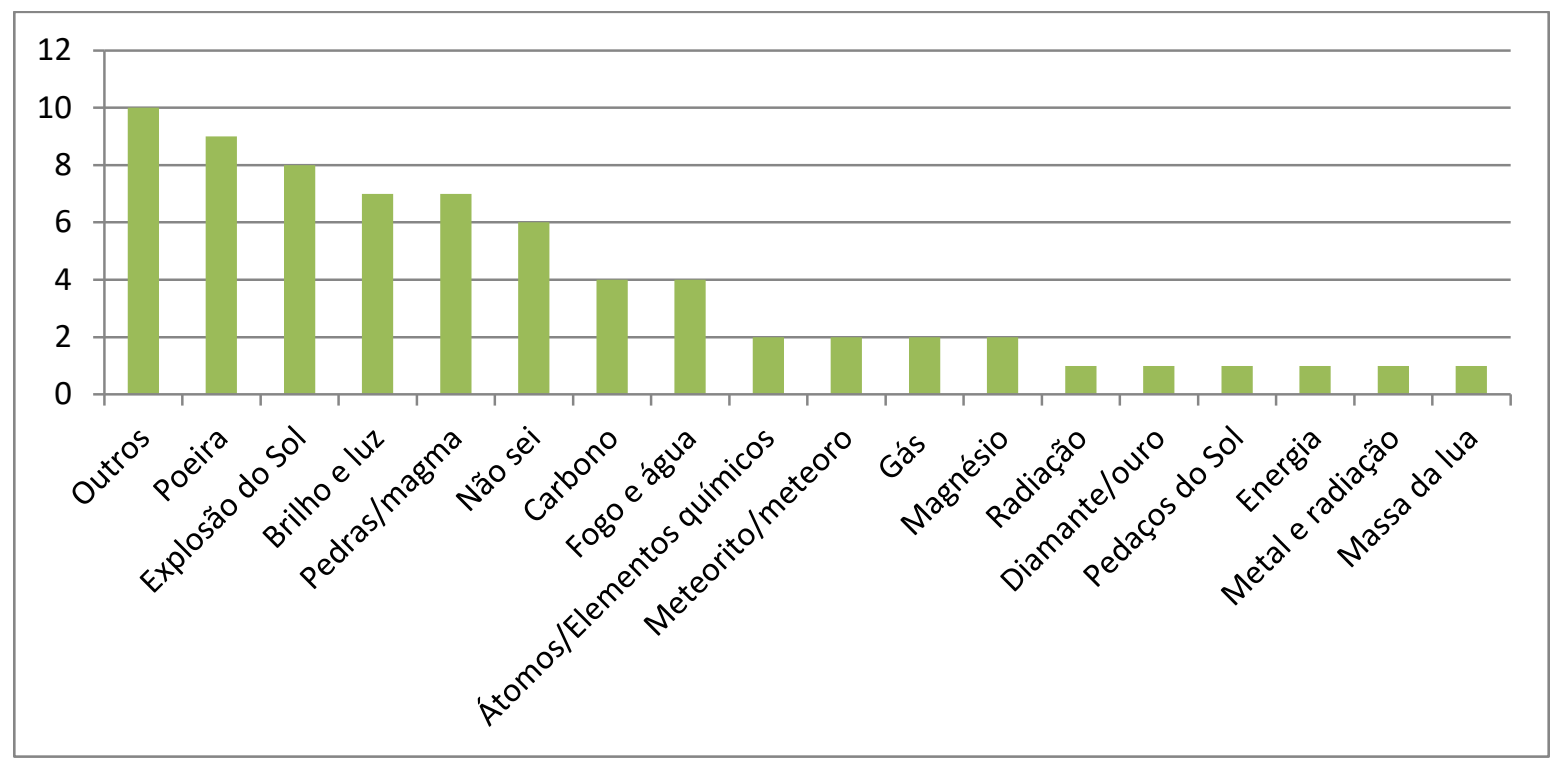

Fonte: Elaborado pela autora

Figura 20 - Gráfico das categorias de respostas para a Questão 3 do QF

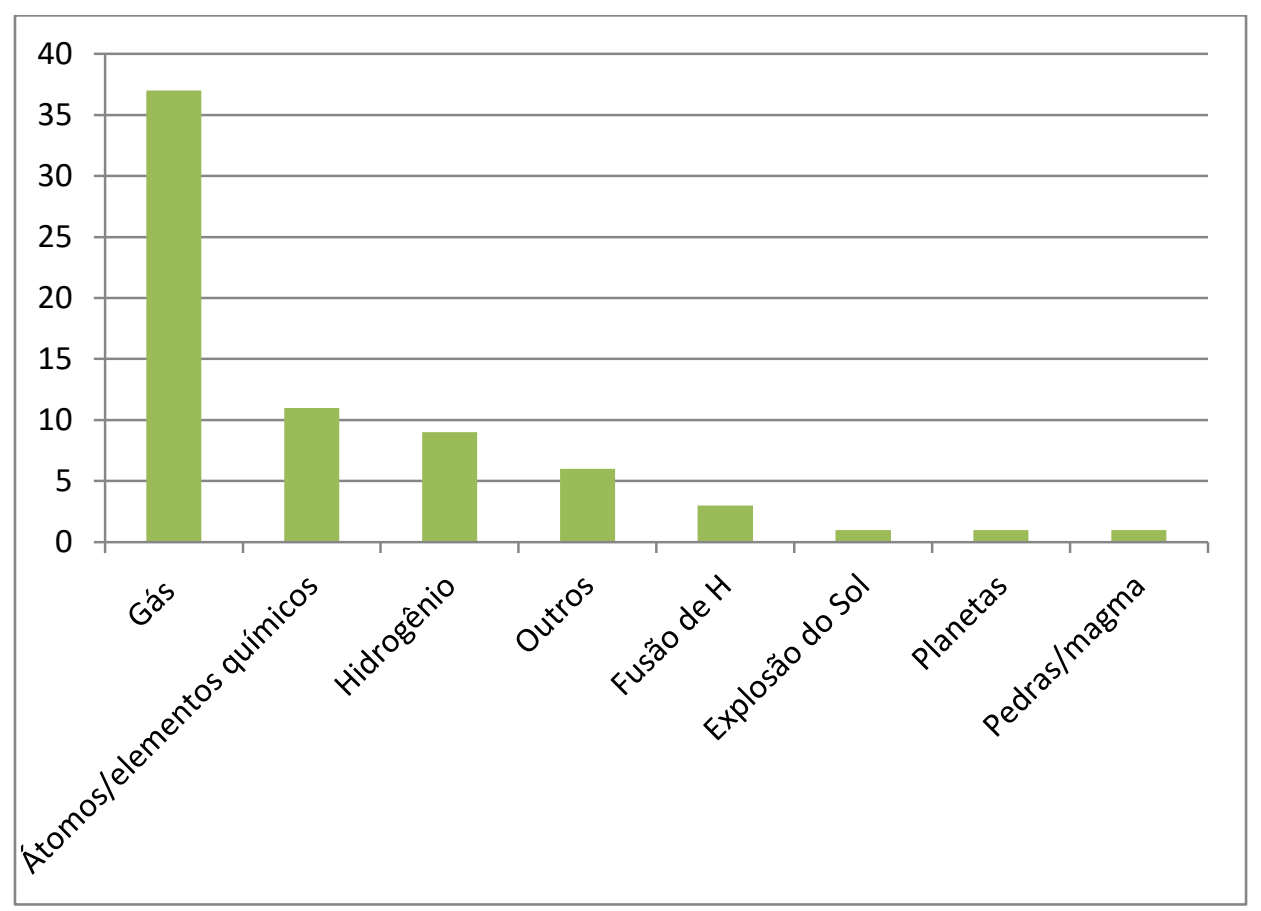

Fonte: Elaborado pela autora 
Quadro 5 - Relação entre as categorias de respostas para a Questão 3 do QI e do QF

\begin{tabular}{|l|c|c|l|c|c|}
\hline \multicolumn{7}{|c|}{ QI } & \multicolumn{2}{c|}{ Questão 3 } \\
\hline \multicolumn{1}{|c|}{ Categoria de resposta } & N & \% & Categoria de resposta & N & \% \\
\hline Elem. biológicos/alimentos/sentimentos & 11 & 15,9 & Gás & 37 & 53,6 \\
\hline Poeira & 9 & 13,0 & Átomos/elem. químicos & 11 & 15,9 \\
\hline Explosão do Sol & 9 & 13,0 & Hidrogênio & 9 & 13,0 \\
\hline Brilho e luz & 8 & 11,6 & Outros & 6 & 8,7 \\
\hline Pedras/magma & 7 & 10,1 & Fusão de H & 3 & 4,3 \\
\hline Elementos químicos & 7 & 10,1 & Explosão do Sol & 1 & 1,4 \\
\hline Não sei & 6 & 8,7 & Planetas & 1 & 1,4 \\
\hline Fogo e água & 4 & 5,8 & Pedras/magma & 1 & 1,4 \\
\hline Meteorito/meteoro & 3 & 4,3 & & & \\
\hline Gás & 2 & 2,9 & & & \\
\hline Radiação & 1 & 1,4 & & & \\
\hline Diamante/ouro & 1 & 1,4 & & & \\
\hline Massa da lua & 1 & 1,4 & & & \\
\hline
\end{tabular}

Fonte: Elaborado pela pesquisadora.

No QI, a maioria dos alunos mostrou não ter noção sobre o assunto. Alguns estudantes usaram uma abordagem abstrata apontando até mesmo sentimentos como componentes dos astros, o que caracterizou a primeira categoria, Elementos biológicos/alimentos/sentimentos (16\%). Em seguida, aparecem as respostas "Poeira" (13\%), "Explosão do Sol" (13\%) e "Brilho e Luz" (11,5\%).

Houve menor número de categorias de respostas ao QF. Notamos uma significativa mudança na categoria de maior frequência, Gás (54\%), seguida de Átomos/Elementos químicos (16\%) e Hidrogênio (13\%).

A Questão 3 apresenta um resultado bastante positivo. Apesar de as categorias não serem muito específicas, demonstram que, de alguma forma, houve aprendizagem sobre o tema, por exemplo, na categoria "Fusão de H” (4\%).

Alguns exemplos estão a seguir:

Aluno 1 - QI: De morango.

Aluno 1-QF: A estrela é formada por uma nuvem de gás.

Aluno 2-QI: A estrela é feita de pedras.

Aluno 2-QF: A estrela é feita de gás.

De acordo com Agan (2004), os alunos que não realizaram nenhum curso de astronomia descrevem de maneira superficial e, às vezes, incorreta a natureza das estrelas, 
por exemplo, afirmam que são feitas de lava ou magma. Já os alunos que possuem ensino formal em astronomia sabem responder corretamente sua composição e sua natureza, descrevendo as estrelas como esferas de gás que produzem energia. No presente trabalho, $10 \%$ dos alunos apontaram pedra ou magma como a composição da estrela, o que vai ao encontro do que mencionado por Agan (2004).

Como mostrado acima, apenas 3\% dos estudantes responderam no QI que a estrela era composta por gás, contrastando com a afirmação Bailey (2009). Na pesquisa desse autor, evidencia-se $80 \%$ dos estudantes que iniciam um curso de introdução à Astronomia respondem corretamente que a estrela é composta por gás.

\subsubsection{Temperatura das estrelas}

A quarta questão solicita que os alunos determinem se a estrela é fria ou quente, ou seja, indiquem a temperatura desta. No QI, a maior parte das respostas refere-se a estrelas quentes (67\%). Foi possível perceber a concepção dos alunos, como demonstrado nas Figuras 21 e 22 e no Quadro 6.

Analisando as categorias de respostas do QI, a maioria afirmou que são quentes (67\%). 22\% alegaram que são frias. Em menor número, também apareceram menções a estrelas quentes e frias $(7 \%)$ e outras respostas $(4 \%)$.

No QF, a maior parte das respostas determinou que as estrelas são quentes (27\%), são muito quentes $(16 \%)$ ou têm temperatura entre $5.000^{\circ} \mathrm{C}$ e $10.000^{\circ} \mathrm{C}(13 \%)$. Outras categorias de respostas foram identificadas:

Aluno 1-QF: As mais novas são quentes e as mais velhas são frias.

Aluno $2-$ QF: Não possui temperatura porque não emite calor.

Figura 21 - Gráfico das categorias de respostas para a Questão 4 do QI

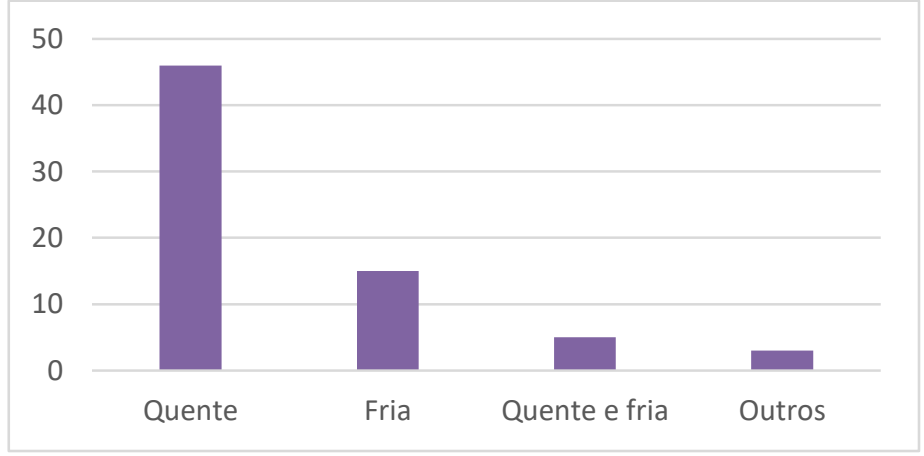

Fonte: Elaborado pela pesquisadora. 
Figura 22 - Gráfico das categorias de respostas para a questão 4 do QF

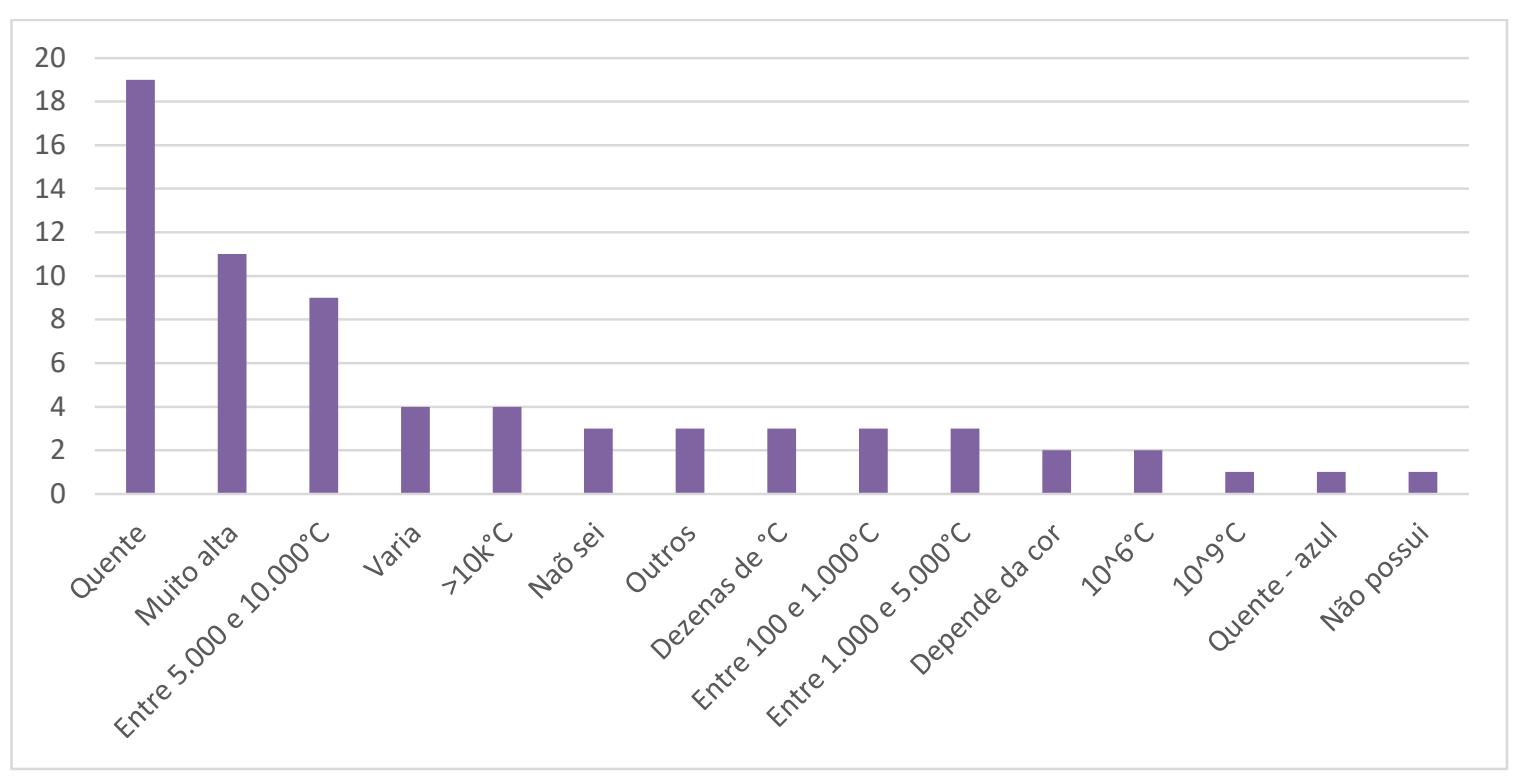

Fonte: Elaborado pela pesquisadora.

Quadro 6 - Relação entre as categorias de respostas para a questão 4 do QI

\begin{tabular}{|l|c|c|l|c|c|}
\hline \multicolumn{7}{|c|}{ Questão 4 } \\
\hline \multicolumn{2}{|c|}{ QI } & \multicolumn{3}{c|}{ QF } \\
\hline Categoria de resposta & $\mathbf{N}$ & $\mathbf{\%}$ & Categoria de resposta & $\mathbf{N}$ & \% \\
\hline Quente & 46 & 66,7 & Quente & 19 & 27,5 \\
\hline Fria & 15 & 21,7 & Muito quente & 11 & 15,9 \\
\hline Quente e fria & 5 & 7,2 & Entre 5.000 e $10.000^{\circ} \mathrm{C}$ & 9 & 13,0 \\
\hline Outros & 3 & 4,3 & Varia & 4 & 5,8 \\
\hline & & & $>10 \mathrm{k}^{\circ} \mathrm{C}$ & 4 & 5,8 \\
\hline & & & Não sei & 3 & 4,3 \\
\hline & & & Outros & 3 & 4,3 \\
\hline & & & Dezenas ${ }^{\circ} \mathrm{C}$ & 3 & 4,3 \\
\hline & & & Entre 100 e $1.000^{\circ} \mathrm{C}$ & 3 & 4,3 \\
\hline & & & Entre 1.000 e $5.0000^{\circ} \mathrm{C}$ & 3 & 4,3 \\
\hline & & & Depende da cor & 2 & 2,9 \\
\hline & & & $10^{\wedge} 6^{\circ} \mathrm{C}$ & 2 & 2,9 \\
\hline & & & Quente - azul & 1 & 1,4 \\
\hline & & & Não possui $^{\wedge}$ & 1 & 1,4 \\
\hline & & & $10^{\wedge} 9^{\circ} \mathrm{C}$ & 1 & 1,4 \\
\hline
\end{tabular}

Fonte: Elaborado pela pesquisadora. 
Em relação à questão de número 4, as respostas foram mais específicas no Questionário Final. Ainda assim, a resposta de maior quantidade foi igual para os dois questionários: quente. O grande desafio aqui é mostrar para os alunos que temperatura é uma grandeza relativa, por isso é muito impreciso dizer apenas que um objeto é quente ou frio. Estrelas conhecidas como "frias" podem possuir temperaturas superficiais em torno de 4000 $\mathrm{K}$, por exemplo.

Algumas respostas do Questionário Final merecem destaque, como "quente-azul" $(1,4 \%)$. Nesse caso, o estudante não colocou valor específico, mas fez a relação correta entre a cor e a temperatura, dizendo que era uma estrela azul e quente. Houve outros discentes que fizeram a mesma relação, afirmando que a temperatura depende da cor da estrela. Nas outras respostas, os alunos apontaram temperaturas específicas, variando desde níveis de calor extremamente baixos para uma estrela, como dezenas de graus Celsius (4\%), até o outro extremo, chegando aos bilhões de graus Celsius $(1,4 \%)$.

Podemos observar a evolução dos alunos nos exemplos a seguir:

Aluno 3 - QI: A estrela é fria.

Aluno 3 -QF: A estrela possui uma temperatura bastante elevada.

Aluno 4 - QI: É uma estrela fria.

Aluno 4-QF: A estrela é quente.

Aluno 5-QI: Ela é fria.

Aluno 5 - QF: Minha estrela é azul, logo sua temperatura é em torno de $25.000^{\circ} \mathrm{C}$.

\subsubsection{A cor das estrelas}

Na questão 5, foi solicitado que os alunos indicassem uma cor para a estrela. As Figuras 23 e 24 e o Quadro 7 mostram as categorias de respostas dos alunos para essa pergunta: 
Figura 23 - Gráfico das categorias de respostas para a Questão 5 do QI

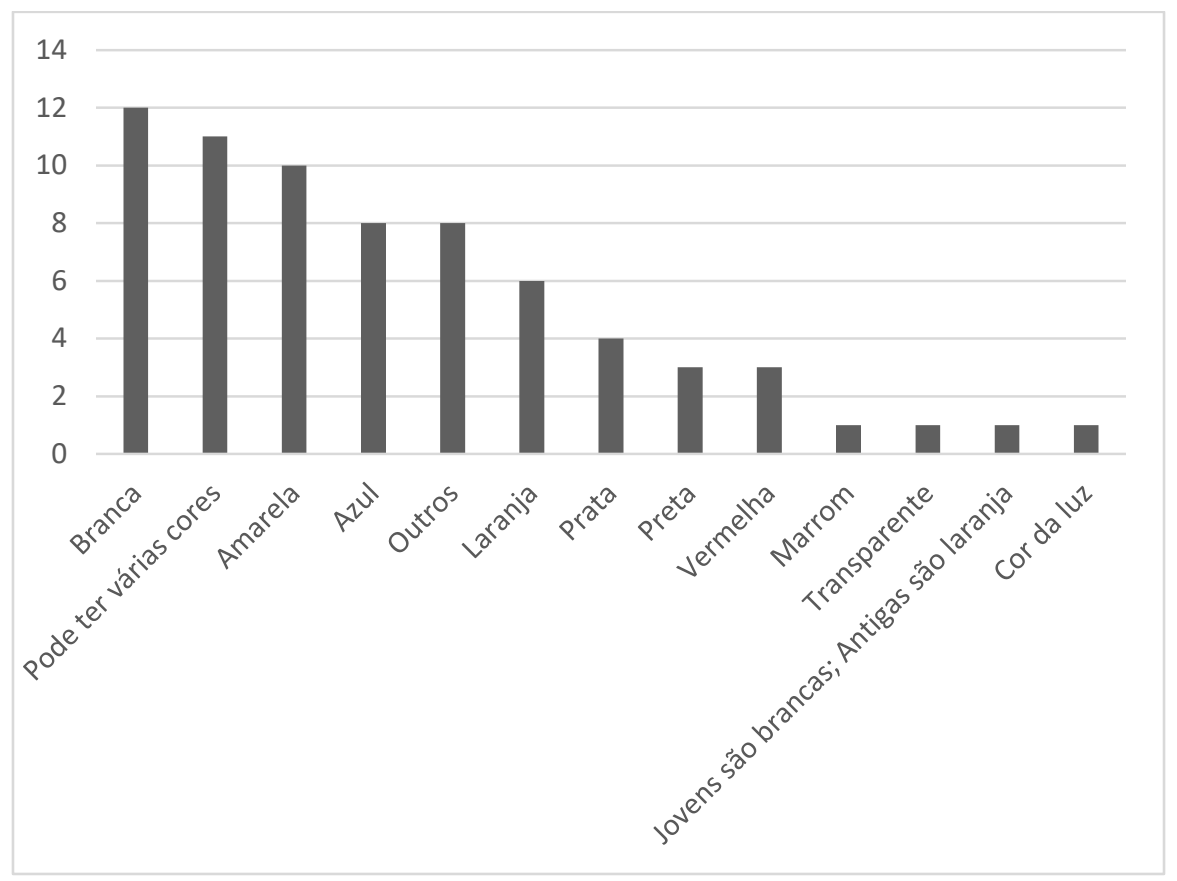

Fonte: Elaborado pela pesquisadora.

Figura 24 - Gráfico das categorias de respostas para a Questão 5 do QF



Fonte: Elaborado pela pesquisadora. 
Quadro 7 - Relação entre as categorias de respostas para a Questão 5 do QI e do QF

\begin{tabular}{|l|c|c|l|l|c|c|}
\hline \multicolumn{9}{|c|}{ QI } & \multicolumn{1}{c|}{ Questão 5 } \\
\hline \multicolumn{2}{|c|}{ Categoria de resposta } & N & \% & \multicolumn{1}{c|}{ Noria de resposta } & N & \% \\
\hline Branca & 12 & 17,4 & Azul & 18 & 26,1 \\
\hline Amarela & 10 & 14,5 & Pode ter várias cores & 16 & 23,2 \\
\hline Pode ter várias cores & 11 & 15,9 & Vermelha & 7 & 10,1 \\
\hline Azul & 8 & 11,6 & Branca & 6 & 8,7 \\
\hline Outros & 8 & 11,6 & Amarela & 6 & 8,7 \\
\hline Laranja & 6 & 8,7 & Laranja & 6 & 8,7 \\
\hline Prata & 4 & 5,8 & Preta & 4 & 5,8 \\
\hline Preta & 3 & 4,3 & Outros & 3 & 4,3 \\
\hline Vermelha & 3 & 4,3 & Prata & 1 & 1,4 \\
\hline Marrom & 1 & 1,4 & Depende da temperatura & 1 & 1,4 \\
\hline Transparente & 1 & 1,4 & Jovens são azuis; Antigas são laranja & 1 & 1,4 \\
\hline Jovens são brancas; Antigas são laranja & 1 & 1,4 & & & \\
\hline Cor da luz & 1 & 1,4 & & & \\
\hline
\end{tabular}

Fonte: Elaborado pela pesquisadora.

Inicialmente, a resposta de maior número foi "Branca" (17\%). Percebemos que a colocação foi baseada apenas na visão que temos quando olhamos para o céu à noite e observamos pintinhos brancos e brilhantes. Em seguida, temos: estrelas amarelas (14\%), várias cores $(16 \%)$ e azul (11\%). Outras categorias também foram citadas com menor frequência.

Aluno 1-QI: A cor da estrela é prata.

Aluno 1-QF: A estrela é vermelha.

As respostas que aparecem em maior quantidade no QF foram estrelas azuis (26\%) e várias cores (23\%). Também no QF aparecem as categorias para estrelas vermelhas (10\%), brancas (9\%), amarelas (9\%) e laranjas (9\%). Constatamos que, no Questionário Final, houve maior detalhamento sobre a cor da estrela; ou seja, os alunos se referiram às cores reais das estrelas, que, muitas vezes, não são perceptíveis a olho nu.

Seguem, novamente, alguns exemplos dos registros dos alunos:

Aluno 2-QI: A estrela é preta.

Aluno 2 - QF: Ela pode apresentar diferentes cores. 


\subsubsection{A idade das estrelas}

A partir da Questão 6, buscamos verificar o conhecimento dos alunos sobre a idade das estrelas. Podemos observar as categorias de respostas para o QI e o QF nas Figuras 25 e 26 e no Quadro 8.

Figura 25 - Gráfico das categorias de respostas para a Questão 6 do QI

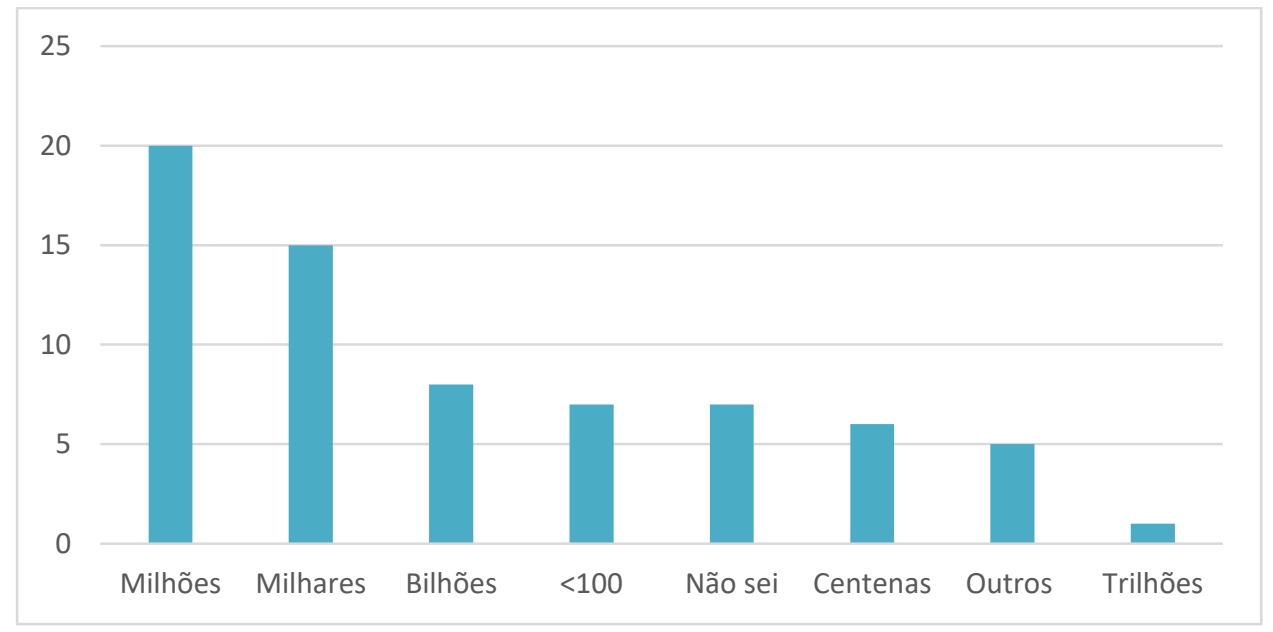

Fonte: Elaborado pela pesquisadora.

O QI mostra que, a princípio, a maior parte dos alunos considerou a idade da estrela na ordem dos milhões de anos (29\%). A segunda categoria mais frequente foi na ordem dos milhares de anos (22\%). Depois, estavam as estrelas com idades na ordem dos bilhões de anos $(11 \%)$. No QF, as categorias mais frequentes foram estrelas com idades na ordem dos bilhões de anos (32\%), dos milhares de anos (23\%) e dos milhões de anos (16\%).

Figura 26 - Gráfico das categorias de respostas para a Questão 6 do QF

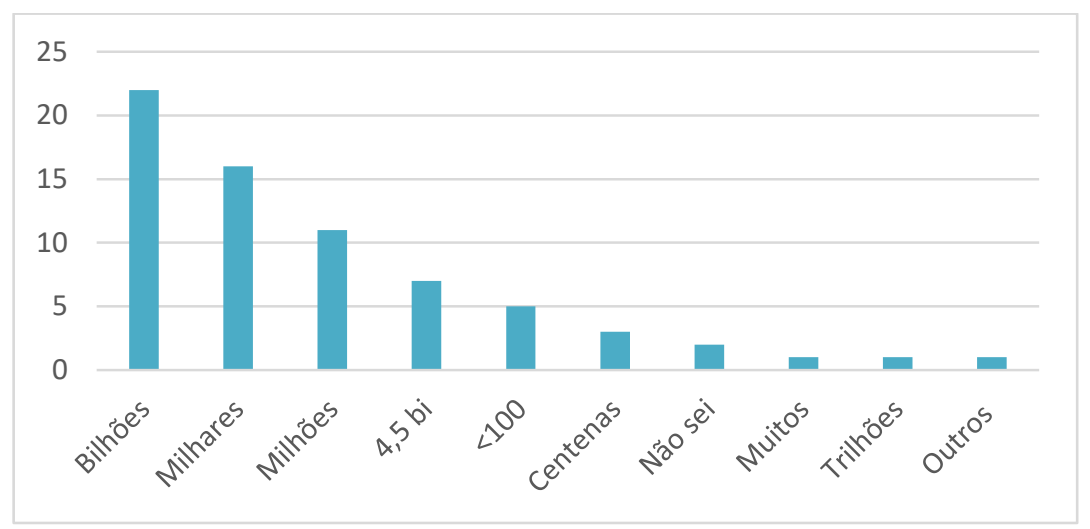

Fonte: Elaborado pela pesquisadora. 
Quadro 8 - Relação entre as categorias de respostas para a Questão 6 do QI e do QF

\begin{tabular}{|l|c|c|l|l|c|}
\hline \multicolumn{7}{|c|}{ QI } & \multicolumn{4}{c|}{ QF } \\
\hline Categoria de resposta & $\mathbf{N}$ & \% & Categoria de resposta & N & \% \\
\hline Milhões & 20 & 29,0 & Bilhões & 22 & 31,9 \\
\hline Milhares & 15 & 21,7 & Milhares & 16 & 23,2 \\
\hline Bilhões & 8 & 11,6 & Milhões & 11 & 15,9 \\
\hline$<100$ & 7 & 10,1 & 4,5 bilhões & 7 & 10,1 \\
\hline Não sei & 7 & 10,1 & $<100$ & 5 & 7,2 \\
\hline Centenas & 6 & 8,7 & Centenas & 3 & 4,3 \\
\hline Outros & 5 & 7,2 & Não sei & 2 & 2,9 \\
\hline Trilhões & 1 & 1,4 & Muitos & 1 & 1,4 \\
\hline & & & Outros & 1 & 1,4 \\
\hline & & & Trilhões & 1 & 1,4 \\
\hline
\end{tabular}

Fonte: Elaborado pela pesquisadora.

Analisando a evolução das categorias, as respostas finais demonstram que grande parte dos alunos assumiu que a estrela tem bilhões de anos. Isso talvez se deva à relação com a idade do Sol, assunto mencionado durante a aplicação da atividade. São expostas algumas colocações dos alunos:

Aluno 1 - QI: A estrela tem 100 anos.

Aluno 1-QF: A estrela possui 4,5 bilhões de anos.

Aluno 2 - QI: Não sei a idade da estrela.

Aluno 2 -QF: A idade da estrela é 4,5 bilhões de anos.

Iachel (2011) menciona que poucos alunos sabem que as estrelas possuem um tempo determinado de ciclo evolutivo. Nesta pesquisa, verificamos que $28 \%$ dos alunos afirmaram que a estrela possui milhões de anos no QI e 31\% dos estudantes asseveraram que ela tem bilhões de anos no QF.

\subsubsection{O tamanho das estrelas}

A Questão 7 buscou identificar o conhecimento dos alunos sobre o tamanho da estrela. Para ter uma resposta mais precisa, foi solicitado que fizessem uma comparação com o tamanho da Terra. As categorias de respostas para o QI e para o QF se apresentam nas Figuras 27 e 28 e no Quadro 9. 
Figura 27 - Gráfico das categorias de respostas para a Questão 7 do QI

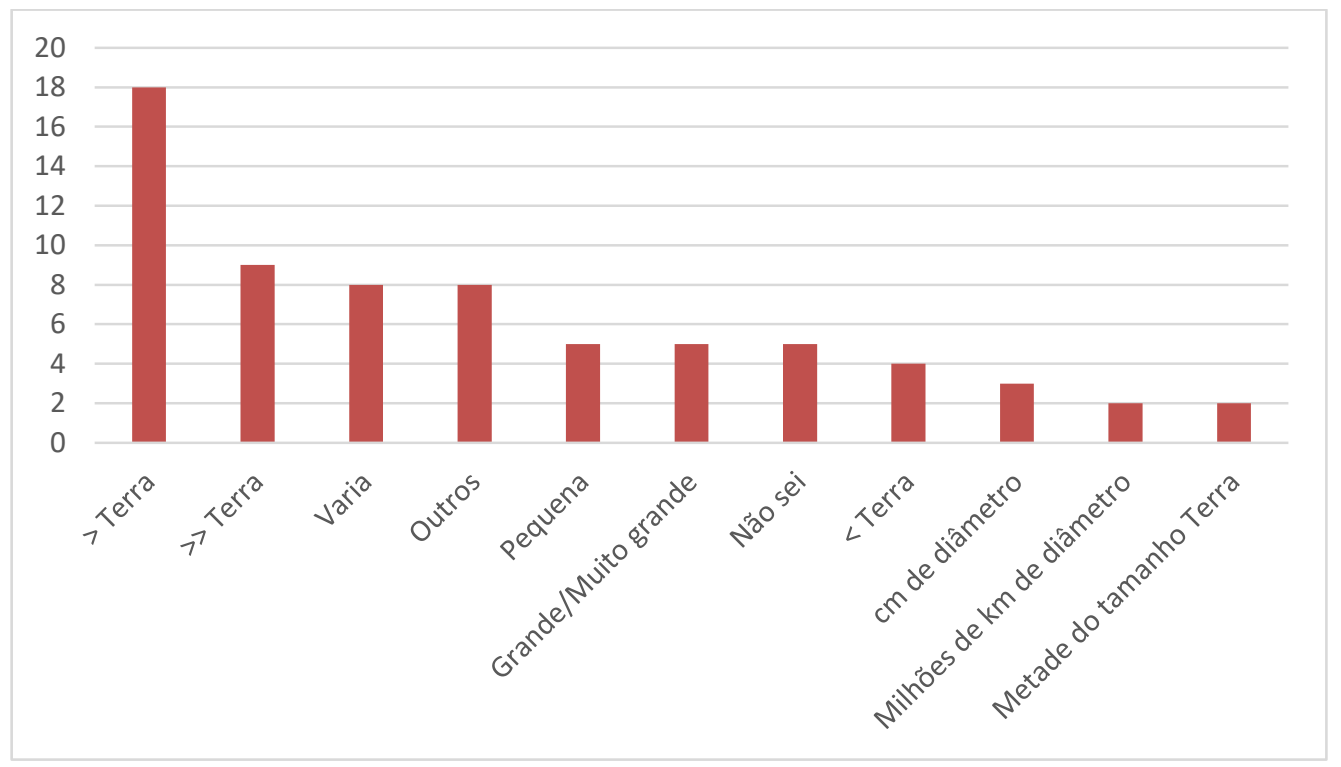

Fonte: Elaborado pela pesquisadora.

No QI, a resposta de maior frequência foi maior do que a Terra (26\%), seguida de muito maior do que a Terra (13\%). Oito alunos disseram que o tamanho da estrela pode variar. Houve também outras categorias em menor quantidade de frequência. Alguns estudantes alegaram que a estrela pode ter seu tamanho na ordem dos centímetros (4\%); e outros assinalaram que ela tem metade do tamanho da Terra (3\%).

Figura 28 - Gráfico das categorias de respostas para a Questão 7 do QF

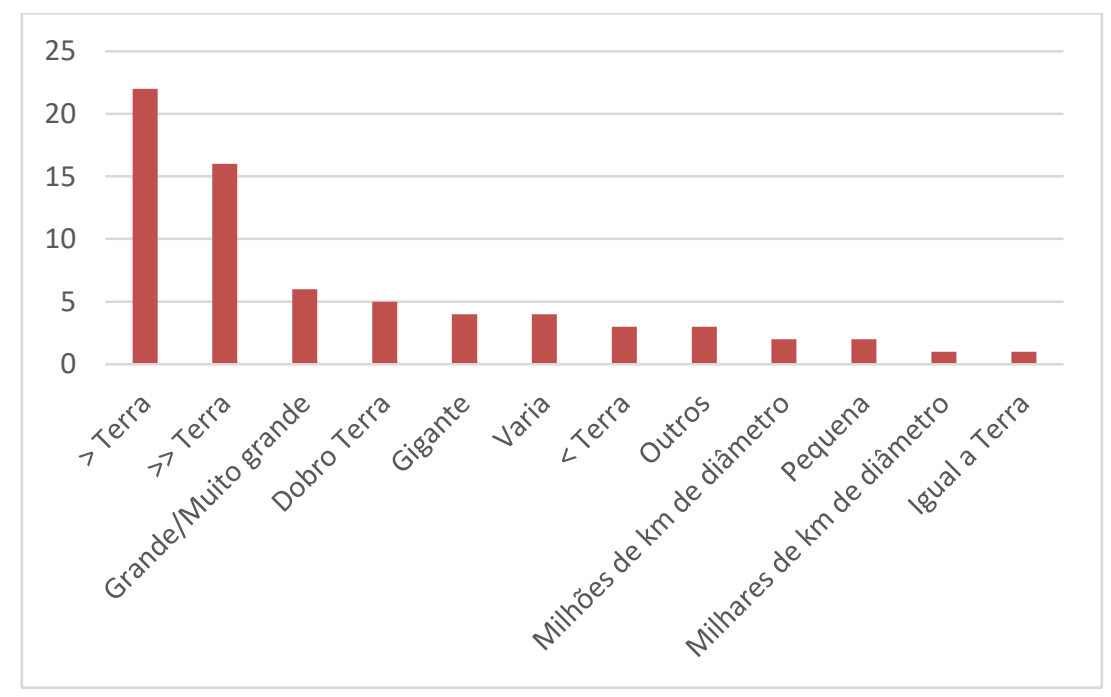

Fonte: Elaborado pela pesquisadora. 
Para o QF, as categorias de respostas mais frequentes foram: maior do que a Terra $(32 \%)$ e muito maior do que a Terra (23\%), assim como no QI. Também houve grande ou muito grande (9\%), o dobro do tamanho da Terra (7\%) e gigante (6\%). Assim como na Questão 4, esta pergunta também tem um fator relativo nas respostas. Há uma dificuldade para identificar o que o estudante julga como "grande" ou "pequeno". De maneira geral, percebemos que as categorias que afirmavam que as estrelas são maiores do que a Terra apareceram com mais frequência no QF, indicando maior clareza e compreensão do assunto por parte dos alunos.

Quadro 9 - Relação entre as categorias de respostas para a Questão 7 do QI e do QF

\begin{tabular}{|l|c|c|l|c|c|}
\hline \multicolumn{7}{|c|}{ QI } & \multicolumn{2}{c|}{ QF } \\
\hline \multicolumn{1}{|c|}{ Questão 7 } \\
\hline Categoria de resposta & $\mathbf{N}$ & $\mathbf{\%}$ & Categoria de resposta & $\mathbf{N}$ & $\%$ \\
\hline Terra & 18 & 26,1 & $>$ Terra & 22 & 31,9 \\
\hline$>$ Terra & 9 & 13,0 & $>>$ Terra & 16 & 23,2 \\
\hline Varia & 8 & 11,6 & Grande/Muito grande & 6 & 8,7 \\
\hline Outros & 8 & 11,6 & Dobro Terra & 5 & 7,2 \\
\hline Pequena & 5 & 7,2 & Gigante & 4 & 5,8 \\
\hline Grande/Muito grande & 5 & 7,2 & Varia & 4 & 5,8 \\
\hline Não sei & 5 & 7,2 & $<$ Terra & 3 & 4,3 \\
\hline$<$ Terra & 4 & 5,8 & Outros & 3 & 4,3 \\
\hline Alguns centímetros & 3 & 4,3 & Milhões de km & 2 & 2,9 \\
\hline Milhões de quilômetros & 2 & 2,9 & Pequena & 2 & 2,9 \\
\hline Metade do tamanho Terra & 2 & 2,9 & Milhares de km & 1 & 1,4 \\
\hline \multicolumn{2}{|c|}{} & & Igual a Terra & 1 & 1,4 \\
\hline
\end{tabular}

Fonte: Elaborado pela pesquisadora.

Para exemplificar, expomos os registros a seguir:

Aluno 1 - QI: A estrela possui $42 \mathrm{~cm}$ de diâmetro.

Aluno 1 - QF: A estrela é maior do que a Terra.

Aluno 2 - QI: O tamanho da estrela é inferior ao da Terra.

Aluno $2-$ QF: A estrela é muito maior do que a Terra.

No que se refere às escalas astronômicas, existe uma dificuldade na real compreensão do tamanho ou das distâncias dos astros no universo, o que é compreensível, uma vez que os parâmetros são completamente diferentes dos que vemos ao longo de nossas vidas e que, se basearmo-nos apenas no conhecimento empírico, estrelas são pequenos pontos brilhantes no 
céu. Isso é demonstrado por Agan (2004) por meio da afirmação de alguns alunos envolvidos em sua pesquisa, os quais disseram que as estrelas são pequenos objetos que podem ser encontrados no Sistema Solar. Essa visão se assemelha à ideia dos antigos gregos de que o tamanho dos astros era tal qual observamos no céu. No presente trabalho, porém, 39\% dos alunos afirmaram que a estrela é maior ou muito maior do que a Terra, diferentemente dos resultados apresentados por Agan (2004).

\subsubsection{Radiação e fusão nuclear}

Na questão de número 8, as perguntas do QI e do QF são diferentes. No primeiro, perguntamos: "Ela emite alguma coisa que você conseguiria sentir, mesmo estando distante dela?”. Já no segundo, indagamos: “Qual o combustível dessa estrela?”. Portanto, não é possível fazer uma comparação direta entre os questionários. Sintetizamos abaixo as categorias de respostas para cada pergunta.

Figura 29 - Gráfico das categorias de respostas para a Questão 8 do QI



Fonte: Elaborado pela pesquisadora. 
Figura 30 - Gráfico das categorias de respostas para a Questão 8 do QF



Fonte: Elaborado pela pesquisadora.

Quadro 10 - Relação entre as categorias de respostas para a Questão 8 do QI e do

\begin{tabular}{|l|c|c|l|c|c|}
\hline \multicolumn{7}{|c|}{ Questão 8 } \\
\hline \multicolumn{2}{|c|}{ QI } & \multicolumn{2}{c|}{ QF } \\
\hline Categoria de resposta & $\mathbf{N}$ & $\mathbf{\%}$ & Categoria de resposta & N & \% \\
\hline Outros & 26 & 37,7 & Elementos químicos & 37 & 53,6 \\
\hline Calor & 18 & 26,1 & Fusão nuclear & 14 & 20,3 \\
\hline Luz & 8 & 11,6 & Gás & 7 & 10,1 \\
\hline Não & 7 & 10,1 & Outros & 6 & 8,7 \\
\hline Brilho & 5 & 7,2 & Não sei & 2 & 2,9 \\
\hline Não sei & 3 & 4,3 & Luz & 2 & 2,9 \\
\hline Radiação & 2 & 2,9 & Átomos & 1 & 1,4 \\
\hline
\end{tabular}

Fonte: Elaborado pela pesquisadora.

Avaliando o QI, a maior parte dos alunos não demonstrou conhecimentos prévios sobre o assunto, resultando na categoria outros (38\%). Alguns exemplos podem ser vistos a seguir. A segunda categoria que apareceu com maior frequência foi calor (26\%), seguida de luz (11\%). 7 alunos (10\%) afirmaram que as estrelas não emitem nada. Também houve a categoria "brilho" (7\%). Ademais, 3 estudantes (4\%) afirmaram não saber se a estrela emite algo. E a categoria de menor incidência foi radiação (3\%). 
Em geral, as categorias para o QI mostram um resultado bastante positivo. Levando em conta que este questionário analisa os conhecimentos prévios dos alunos, grande parte das categorias são respostas corretas, alguns exemplos são mostrados a seguir:

Aluno 1-QI: A estrela emite luz.

Aluno 2 - QI: Ela emite calor.

No QF, a categoria de maior número foi elementos químicos (54\%), seguida de fusão nuclear $(20 \%)$ e gás $(10 \%)$. Outras respostas também se revelaram, mas tiveram menor frequência.

As categorias para o QF também são bastante positivas e mostram que os alunos adquiriram conhecimento a respeito do assunto, como podemos ver abaixo.

Aluno 3 - QF: O combustível é a fusão nuclear.

Aluno 4 - QF: Os elementos químicos e a fusão nuclear são o combustível da estrela.

De acordo com Bailey (2009), em seu estudo sobre o conhecimento prévio dos alunos a respeito das estrelas, apenas $3 \%$ dos estudantes mencionaram a fusão nuclear como a fonte de energia desses astros. Além disso, 32\% dos alunos acreditavam que a energia das estrelas é produzida a partir de algum processo de explosão ou queima de combustível. Esse é um ponto que se deve levar em consideração, uma vez que, por exemplo, é comum ouvir a afirmação incorreta de que o Sol está "queimando" hidrogênio, o que pode induzir o aluno a uma concepção errônea a respeito da fusão nuclear.

É possível verificar também nos resultados deste trabalho que alguns alunos acreditam que as estrelas estão "queimando" ou "pegando fogo", por causa de seu brilho e de sua temperatura. É importante que o professor atente aos termos utilizados durante a aula para não causar essa compreensão equivocada. A fonte de energia das estrelas é a fusão nuclear, um processo diferente da combustão química.

\subsubsection{Equilíbrio Hidrostático}

Com a Questão 9 ("Você pode observar essa estrela por muitos anos sem perceber qualquer mudança. Como você acha que ela se mantém dessa forma?"), o objetivo era identificar se os alunos tinham noção sobre o ciclo estelar e sobre as escalas de tempo na Astronomia. As categorias de respostas se apresentam nas Figuras 31 e 32 e no Quadro 11. 
Figura 31 - Gráfico das categorias de respostas para a Questão 9 do QI

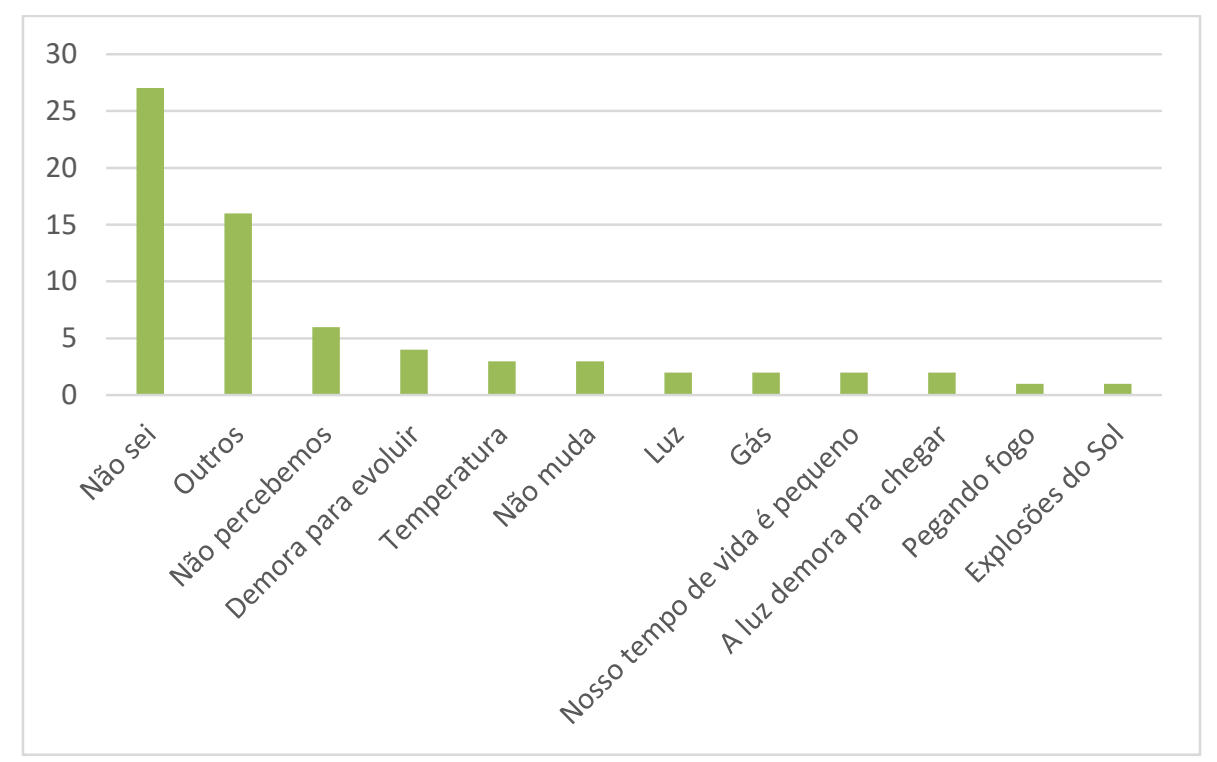

Fonte: Elaborado pela pesquisadora.

Figura 32 - Gráfico das categorias de respostas para a Questão 9 do QF

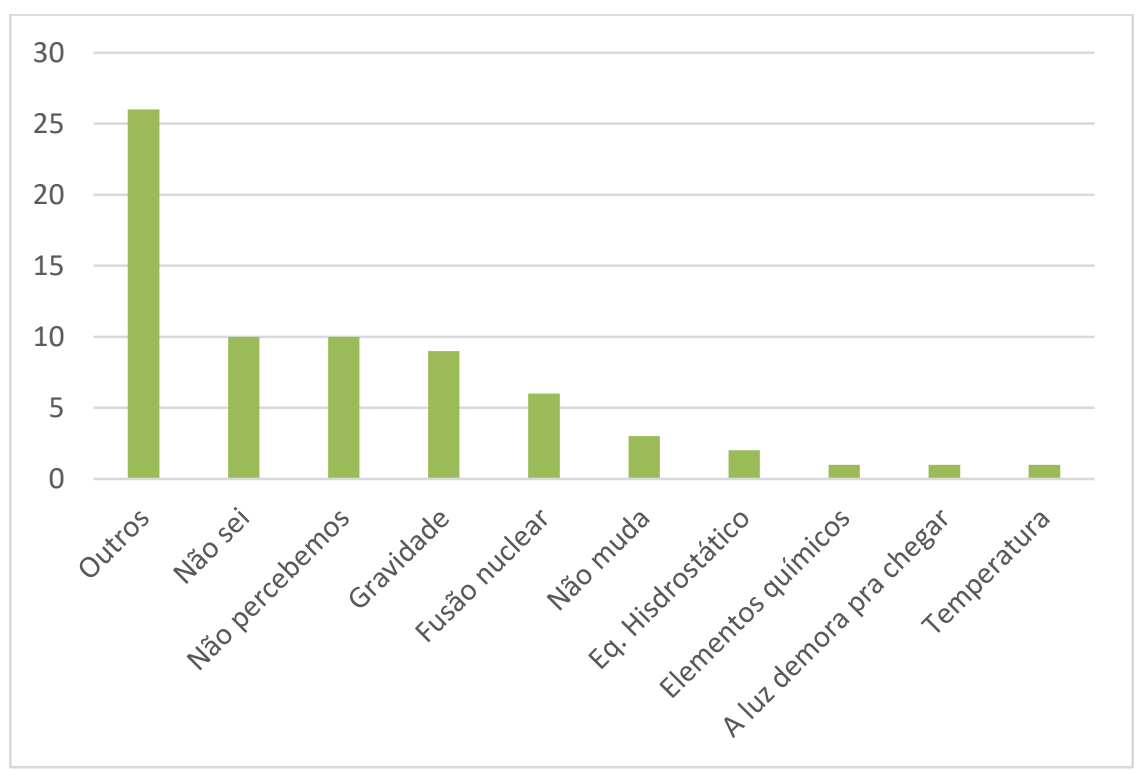

Fonte: Elaborado pela pesquisadora. 
Quadro 11 - Relação entre as categorias de respostas para a Questão 9 do QI e do QF

\begin{tabular}{|l|c|c|l|c|c|}
\hline \multicolumn{7}{|c|}{ QI } & \multicolumn{2}{c|}{ QFestão 9 } \\
\hline \multicolumn{1}{|c|}{ Categoria de resposta } & N & \% & Categoria de resposta & N & \% \\
\hline Não sei & 27 & 39,1 & Outros & 26 & 37,7 \\
\hline Outros & 16 & 23,2 & Não sei & 10 & 14,5 \\
\hline Não percebemos & 6 & 8,7 & Não percebemos & 10 & 14,5 \\
\hline Demora para evoluir & 4 & 5,8 & Gravidade & 9 & 13,0 \\
\hline Temperatura & 3 & 4,3 & Fusão nuclear & 6 & 8,7 \\
\hline Não muda & 3 & 4,3 & Não muda & 3 & 4,3 \\
\hline Luz & 2 & 2,9 & Equilibrio Hidrostático & 2 & 2,9 \\
\hline Gás & 2 & 2,9 & Elementos químicos & 1 & 1,4 \\
\hline Nosso tempo de vida é pequeno & 2 & 2,9 & A luz demora para chegar & 1 & 1,4 \\
\hline A luz demora para chegar & 2 & 2,9 & Temperatura & 1 & 1,4 \\
\hline Pegando fogo & 1 & 1,4 & & & \\
\hline Explosões do Sol & 1 & 1,4 & & & \\
\hline
\end{tabular}

Fonte: Elaborado pela pesquisadora.

No QI, a maioria dos alunos não soube responder à questão (40\%). Outras categorias se revelaram em seguida (23\%). Entre ela estavam: percebemos (9\%), demora para evoluir $(6 \%)$ e temperatura (4\%). Além dessas, houve outras categorias presentes em menor quantidade.

Com relação ao QF, as duas categorias mais frequentes foram: outros (38\%) e não sei (14\%). Também apareceram as categorias: não percebemos (14\%), gravidade (13\%) e fusão nucelar $(9 \%)$.

Levando em conta a maior quantidade de respostas nos questionários, esta questão, talvez por ser um pouco mais complexa, indicou falta de clareza por parte dos alunos. Apesar disso, houve, em menor quantidade, respostas corretas, indicando que os estudantes adquiriram conhecimento, como exemplos temos as colocações destacadas a seguir:

Aluno 1 - QI: Não sei responder.

Aluno 1-QF: A estrela se mantém com a fusão nuclear e a gravidade.

Aluno 2 - QI: Não sei como a estrela se mantém dessa forma.

Aluno 2 - QF: O equilíbrio entre a pressão interna e a gravidade mantém a estrela dessa forma. 
4.1.10 Formação estelar e importância da luz para as estrelas

Assim como a oitava questão, a décima também possui duas perguntas diferentes para os dois questionários. O QI se refere à noção de evolução estelar e ao início do ciclo estelar (“Ela sempre foi assim ou era diferente quando se formou?”). E o QF diz respeito à luz e a sua importância na Astrofísica Estelar ("O que é luz e qual sua importância para as estrelas?”). As Figuras 33 e 34 e o Quadro 12 mostram as categorias de respostas para o QI e o QF.

No QI, a maioria dos estudantes afirmou que a estrela era diferente quando se formou (36\%); 21 alunos (30\%) acreditavam que as estrelas sempre foram assim; e 9 alunos (13\%) revelaram não saber sobre o assunto. Houve a presença de outras categorias também para o QI, em menor número. Mencionamos alguns exemplos a seguir:

Aluno 1 - QI: Quando se formou, o brilho da estrela era menor.

Aluno 2 - QI: Ela era bem pequena e foi aumentando de tamanho aos poucos.

Figura 33 - Gráfico das categorias de respostas para a Questão 10 do QI

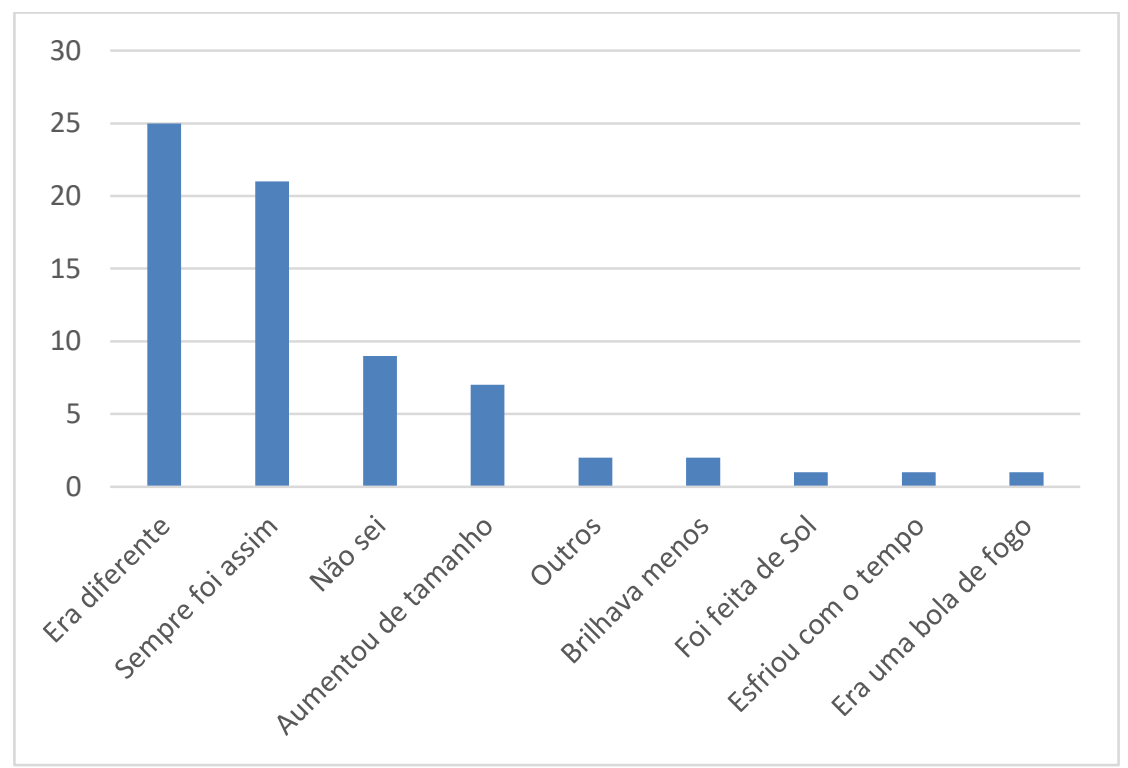

Fonte: Elaborado pela pesquisadora. 
Figura 34 - Gráfico das categorias de respostas para a Questão 10 do QF



Fonte: Elaborado pela pesquisadora.

Quadro 12 - Relação entre as categorias de respostas para a Questão 10 do QI

\begin{tabular}{|l|c|c|l|c|c|}
\hline \multicolumn{7}{|c|}{ QI } & \multicolumn{1}{c|}{ QF } \\
\hline Categoria de resposta & N & \% & \multicolumn{1}{c|}{ Categoria de resposta } & N & \% \\
\hline Era diferente & 25 & 36,2 & Não sei & 15 & 21,7 \\
\hline Sempre foi assim & 21 & 30,4 & Outros & 14 & 20,3 \\
\hline Não sei & 9 & 13,0 & Onda eletromagnética & 11 & 15,9 \\
\hline Aumentou de tamanho & 7 & 10,1 & Energia & 10 & 14,5 \\
\hline Outros & 2 & 2,9 & Observação das estrelas/onda & 9 & 13,0 \\
\hline Brilhava menos & 2 & 2,9 & Radiação eletromagnética & 3 & 4,3 \\
\hline Foi feita de Sol & 1 & 1,4 & Identificar a estrela & 3 & 4,3 \\
\hline Esfriou com o tempo & 1 & 1,4 & Queima de combustível & 1 & 1,4 \\
\hline Era uma bola de fogo & 1 & 1,4 & Importante para queimar combustível & 1 & 1,4 \\
\hline & & & Combustível & 1 & 1,4 \\
\hline & & & Faz emitir radiação & 1 & 1,4 \\
\hline
\end{tabular}

Fonte: Elaborado pela pesquisadora.

Com relação ao QF, a maior parte dos estudantes admitiu não saber responder à pergunta (22\%). Outras afirmações, como as exemplificadas abaixo, apareceram em seguida (20\%). Também se desvelaram os registros: onda eletromagnética (16\%) e energia (14\%). Além disso, foram assinaladas outras categorias menos frequentes, como podemos ver abaixo:

Aluno 3 -QF: A luz é energia e o combustível das estrelas.

Aluno $4-$ QF: Luz é onda eletromagnética que faz a estrela ser visível. 


\subsubsection{O fim das estrelas}

Na Questão 11 (“Ela vai ficar assim para sempre? Em caso negativo, o que vai acontecer com ela depois?"), perguntamos sobre o ciclo estelar mais uma vez; porém, nesse momento, a intenção era identificar se os alunos possuíam conhecimento sobre o fim das estrelas. As Figuras 35 e 36 e o Quadro 13 apresentam as categorias de respostas para o QI e o QF. Por se tratar de uma questão um tanto intrigante, houve grande quantidade de categorias de respostas para os questionários.

No QI, a colocação presente em maior quantidade foi a de que a estrela nunca vai mudar (19\%), seguida das soluções "não sei” (11\%) e "vai explodir" (10\%). No QF, as categorias mais frequentes foram: a estrela vai morrer (20\%), vai explodir (17\%) e vai ficar assim para sempre $(9 \%)$.

Figura 35 - Gráfico das categorias de respostas para a Questão 11 do QI

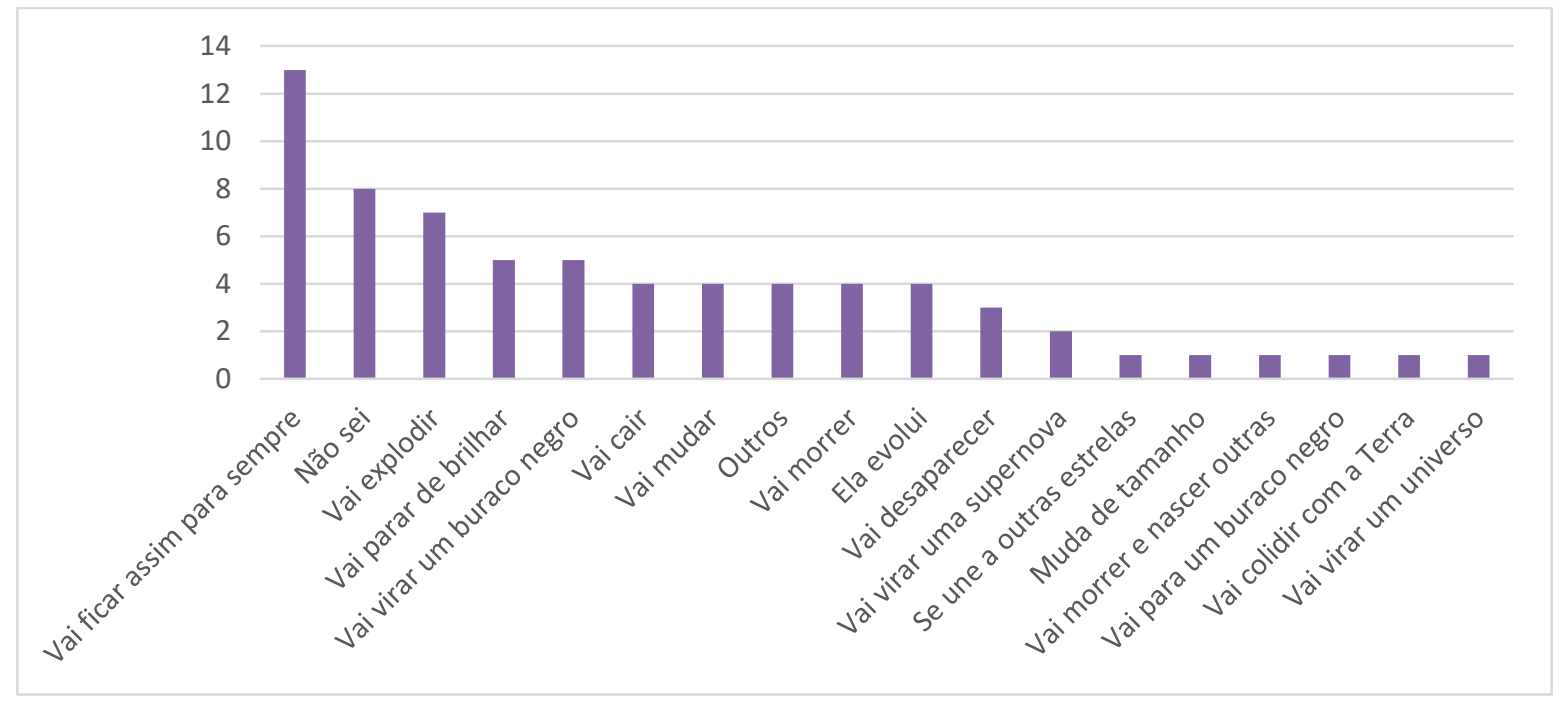

Fonte: Elaborado pela pesquisadora. 
Figura 36 - Gráfico das categorias de respostas para a Questão 11 do QF

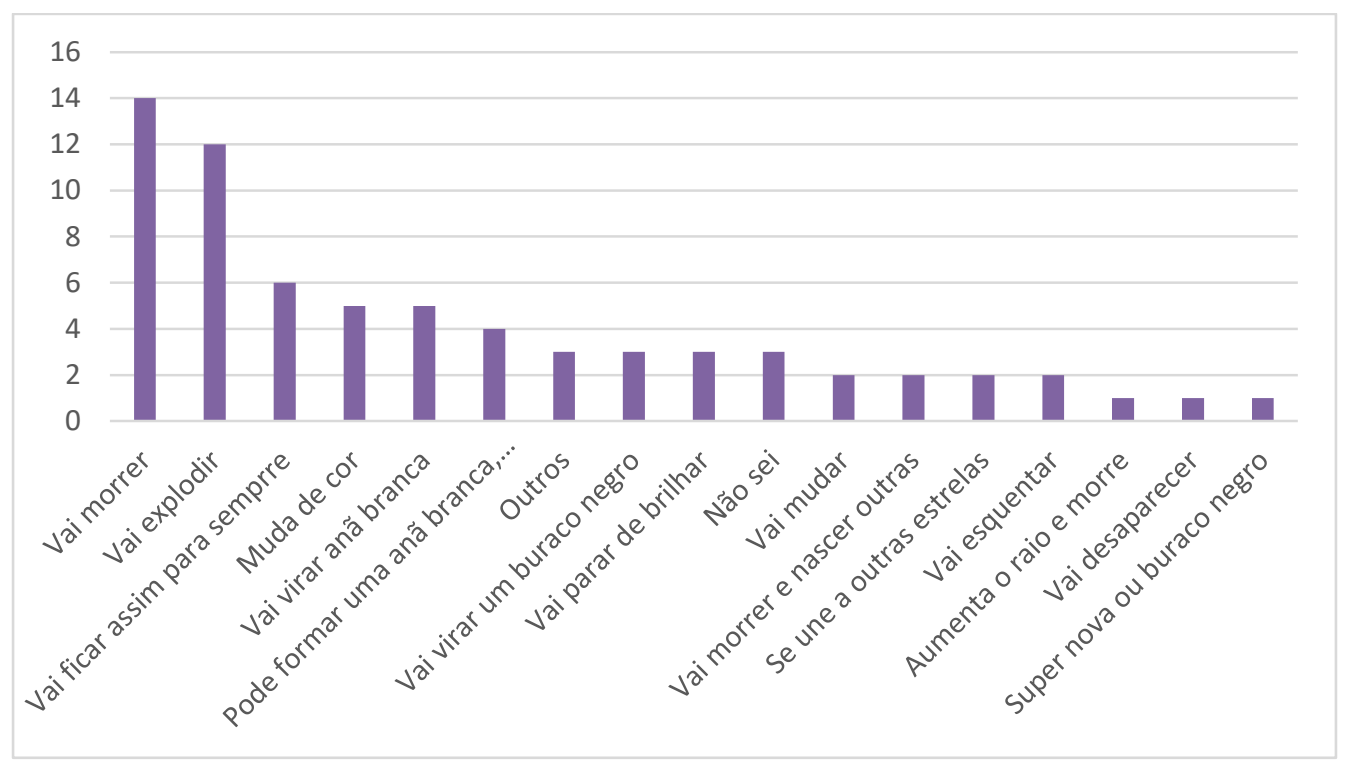

Fonte: Elaborado pela pesquisadora.

Quadro 13 - Relação entre as categorias de respostas para a Questão 11 do QI e do QF

\begin{tabular}{|c|c|c|c|c|c|}
\hline \multicolumn{6}{|c|}{ Questão 11} \\
\hline \multicolumn{3}{|l|}{ QI } & \multicolumn{3}{|l|}{ QF } \\
\hline Categoria de resposta & $\mathbf{N}$ & $\%$ & Categoria de resposta & $\mathbf{N}$ & $\%$ \\
\hline Vai ficar assim para sempre & 13 & 18,8 & Vai morrer & 14 & 20,3 \\
\hline Não sei & 8 & 11,6 & Vai explodir & 12 & 17,4 \\
\hline Vai explodir & 7 & 10,1 & Vai ficar assim para sempre & 6 & 8,7 \\
\hline Vai parar de brilhar & 5 & 7,2 & Muda de cor & 5 & 7,2 \\
\hline Vai virar um buraco negro & 5 & 7,2 & Vai virar anã branca & 5 & 7,2 \\
\hline Vai cair & 4 & 5,8 & Pode formar uma anã branca, buraco negro ou supernova & 4 & 5,8 \\
\hline Vai mudar & 4 & 5,8 & Outros & 3 & 4,3 \\
\hline Outros & 4 & 5,8 & Vai virar um buraco negro & 3 & 4,3 \\
\hline Vai morrer & 4 & 5,8 & Vai parar de brilhar & 3 & 4,3 \\
\hline Ela evolui & 4 & 5,8 & Não sei & 3 & 4,3 \\
\hline Vai desaparecer & 3 & 4,3 & Vai mudar & 2 & 2,9 \\
\hline Vai virar uma supernova & 2 & 2,9 & Vai morrer e nascer outras & 2 & 2,9 \\
\hline Se une a outras estrelas & 1 & 1,4 & Se une a outras estrelas & 2 & 2,9 \\
\hline Muda de tamanho & 1 & 1,4 & Vai esquentar & 2 & 2,9 \\
\hline Vai morrer e nascer outras & 1 & 1,4 & Aumenta o raio e morre & 1 & 1,4 \\
\hline Vai para um buraco negro & 1 & 1,4 & Vai desaparecer & 1 & 1,4 \\
\hline Vai colidir com a Terra & 1 & 1,4 & Supernova ou buraco negro & 1 & 1,4 \\
\hline Vai virar um universo & 1 & 1,4 & & & \\
\hline
\end{tabular}

Fonte: Elaborado pela pesquisadora.

Analisando a Questão 11, notamos uma evolução positiva por parte dos alunos. Inicialmente, a maioria deles acreditava que as estrelas eram imutáveis. Ao final da atividade, a concepção que apareceu em maior quantidade foi a de que a estrela tem um fim.

A evolução de alguns alunos pode ser observada a seguir: 
Aluno 1 - QI: A estrela vai ficar assim para sempre

Aluno 1-QF: A estrela vai explodir e dar origem a outras estrelas.

Aluno 2 - QI: Não sei responder.

Aluno 2 - QF: A estrela vai virar uma anã branca.

Aluno 3 - QI: Não sei responder.

Aluno 3 - QF: Ela não vai ficar assim para sempre, um dia ela vai morrer.

\subsubsection{A importância da gravidade no ciclo estelar}

A Questão 12 (“Qual o papel da gravidade na formação e na evolução das estrelas?”) estava apenas no Questionário Final e objetivava identificar se os alunos perceberam a importância da gravidade durante a evolução estelar. As categorias de respostas para o QF aparecem na figura 37 e no Quadro 14.

Figura 37 - Gráfico das categorias de respostas para a Questão 12 do QF

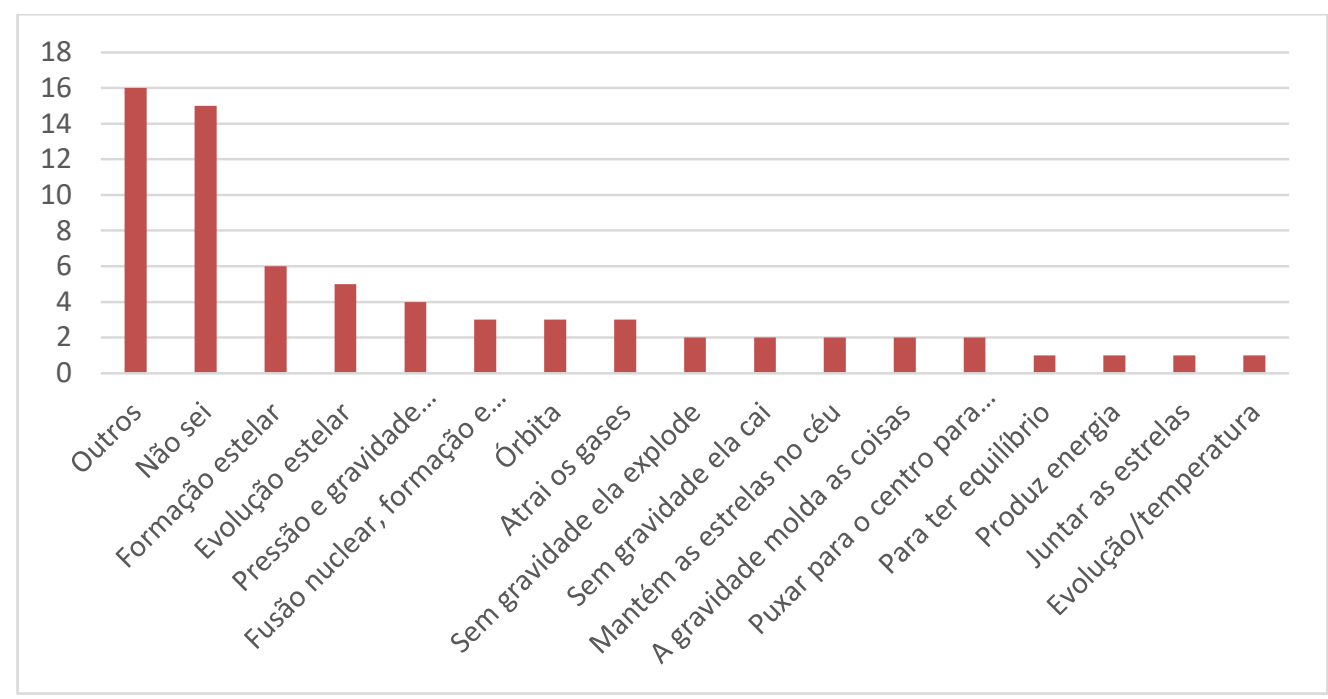

Fonte: Elaborado pela pesquisadora.

A categoria da maioria dos estudantes (23\%) é exemplificada com esta assertiva do Aluno 1: “A gravidade ajuda a estrela a se manter no espaço". 15 alunos (22\%) assinalaram não saber a resposta; 6 alunos acreditavam que a gravidade é importante para a formação das estrelas; 5 alunos (7\%) responderam que era a evolução estelar. Outras categorias aparecem em menor quantidade. 
Quadro 14 - Relação entre as categorias de respostas para a Questão 12 do QF

\begin{tabular}{|l|c|c|}
\hline \multicolumn{3}{|c|}{ Questão 12 } \\
\hline \multicolumn{3}{|c|}{ QF } \\
\hline Outegoria de resposta & N & $\%$ \\
\hline Não sei & 16 & 23,2 \\
\hline Formação estelar & 15 & 21,7 \\
\hline Evolução estelar & 6 & 8,7 \\
\hline Pressão e gravidade mantêm a estrela & 5 & 7,2 \\
\hline Fusão nuclear, formação e evolução estelar & 4 & 5,8 \\
\hline Órbita & 3 & 4,3 \\
\hline Atrai os gases & 3 & 4,3 \\
\hline Sem gravidade ela explode & 3 & 4,3 \\
\hline Sem gravidade ela cai & 2 & 2,9 \\
\hline Mantém as estrelas no céu & 2 & 2,9 \\
\hline A gravidade molda as coisas & 2 & 2,9 \\
\hline Puxar para o centro para formar buraco negro & 2 & 2,9 \\
\hline Para ter equilibrio & 1 & 1,4 \\
\hline Produz energia & 1 & 1,4 \\
\hline Juntar as estrelas & 1 & 1,4 \\
\hline Evolução/temperatura & 1 & 1,4 \\
\hline
\end{tabular}

Fonte: Elaborado pela pesquisadora.

A gravidade é um dos principais fatores envolvidos na formação e na evolução estelar; porém, dificilmente é feita tal relação, como pode ser verificado neste trabalho e em outros artigos publicados. Bailey (2009), em seu estudo sobre concepções prévias, por exemplo, afirma que somente $16 \%$ dos estudantes envolvidos apontaram a gravidade como um elemento importante para a formação estelar. No caso desta pesquisa, verificou-se, no QF, que $45 \%$ dos estudantes responderam de maneira errada ou afirmaram não saber o papel da gravidade na formação e na evolução estelar. Apesar de não ser a maioria, os $45 \%$ representam as maiores categorias de respostas para esta questão, como mostra a Figura 37. 


\subsubsection{Formação dos elementos químicos nas estrelas}

Assim como na questão anterior, a Questão 13 (“QQual a relação entre as estrelas e os elementos químicos?") também aparece apenas no QF. Aqui, procuramos identificar o conhecimento dos alunos sobre a relação entre as estrelas e os elementos químicos.

A categoria de maior número informava que as estrelas produzem os elementos químicos (29\%). A segunda categoria mais frequente indicava que os alunos não sabem as respostas (22\%). 11 alunos (16\%) acreditavam que as estrelas são formadas pelos elementos químicos. Outras categorias se mostraram em menor frequência.

A última questão mostra um resultado positivo. Indica que a maior parte dos estudantes adquiriu conhecimento sobre o assunto e respondeu de maneira correta.

Figura 37 - Gráfico das categorias de respostas para a Questão 13 do QF

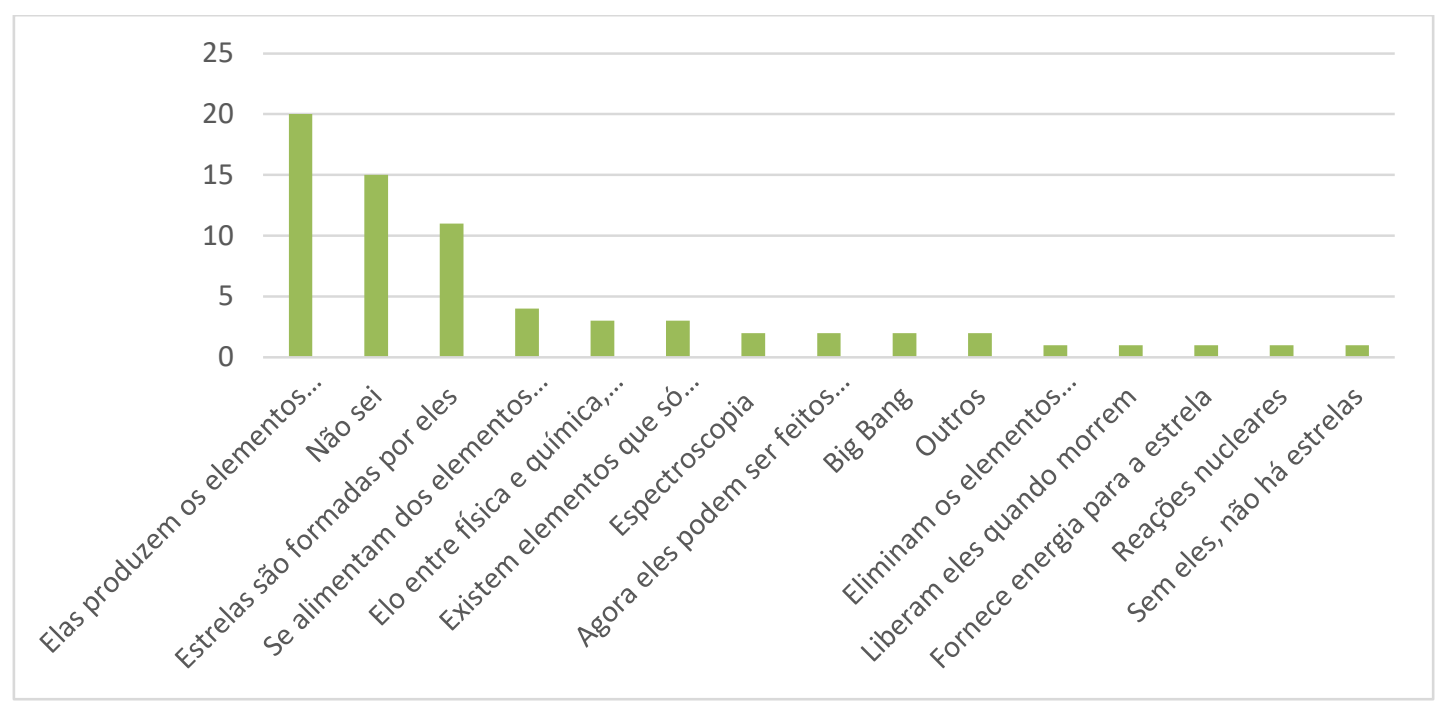

Fonte: Elaborado pela pesquisadora. 
Quadro 15 - Relação entre as categorias de respostas para a Questão 13 do QF

\begin{tabular}{|c|c|c|}
\hline \multicolumn{3}{|l|}{ Questão 12} \\
\hline \multicolumn{3}{|l|}{$\mathbf{Q F}$} \\
\hline Categoria de resposta & $\mathbf{N}$ & $\%$ \\
\hline Elas produzem os elementos químicos & 20 & 29,0 \\
\hline Não sei & 15 & 21,7 \\
\hline Estrelas são formadas por eles & 11 & 15,9 \\
\hline Se alimentam dos elementos químicos & 4 & 5,8 \\
\hline Elo entre física e química, reações nucleares & 3 & 4,3 \\
\hline Existem elementos que só são encontrados nas estrelas & 3 & 4,3 \\
\hline Espectroscopia & 2 & 2,9 \\
\hline Agora eles podem ser feitos na Terra & 2 & 2,9 \\
\hline Big Bang & 2 & 2,9 \\
\hline Outros & 2 & 2,9 \\
\hline Eliminam os elementos químicos & 1 & 1,4 \\
\hline Liberam eles quando morrem & 1 & 1,4 \\
\hline Fornece energia para a estrela & 1 & 1,4 \\
\hline Reações nucleares & 1 & 1,4 \\
\hline Sem eles, não há estrelas & 1 & 1,4 \\
\hline
\end{tabular}

Fonte: Elaborado pela pesquisadora.

\subsection{As trajetórias de alguns alunos}

Também é possível utilizar os dados de maneira a analisar a evolução individual de alguns alunos, como mostram os Quadros 16, 17 e 18. As concepções dos alunos foram evidenciadas com as falas durante a atividade e com as respostas aos questionários. Será mostrado como os alunos expuseram suas falas a partir do prosseguimento da aula. A aula desenvolvida levou em conta uma sequência, que mostramos novamente abaixo.

Galáxias/distâncias $\rightarrow$ Céu estrelado $\rightarrow$ Constelações $\rightarrow$ Magnitude $\rightarrow$ Fluxo $\rightarrow$

Cor e temperatura $\rightarrow$ Radiação $\rightarrow$ Diagrama $H R \rightarrow$ Nuvem molecular $\rightarrow$

Teorema do Virial $\rightarrow$ Gravidade e pressão $\rightarrow$ Fusão Nuclear $\rightarrow$ Produção de energia $\rightarrow$ Equilíbrio Hidrostático $\rightarrow$ Evolução estelar $\rightarrow$ Anã Branca $\rightarrow$ Buraco Negro/Estrela de Nêutrons.

As análises foram feitas com base na ordem cronológica da atividade. Primeiro, lemos os dados resultantes do QI, depois os registros das aulas e, por fim, as informações provenientes do QF. No que se refere aos tópicos das aulas, foram selecionados os temas 
mais importantes e comentados durante o curso: luz, gravitação, temperatura, composição das estrelas, fusão nuclear, equilíbrio hidrostático e fim das estrelas. Outros assuntos mais específicos poderão ser tratados no texto.

O Quadro 16 apresenta os dados do Aluno 1 ao longo da atividade: respostas ao QI, falas durante as aulas e registros vinculados ao QF. É possível notar, logo no QI, que esse estudante demonstrou não ter conhecimentos prévios sobre o assunto da Astrofísica Estelar, pois declarou não saber responder ou deixou em branco a maioria das questões, como é o caso da pergunta sobre a luz, primeiro tema presente quadro. Durante as aulas, após uma discussão sobre o que é a luz, afirmou: “As estrelas emitem luz e energia e aquecem a Terra”. Percebemos que o discente indicou aquilo que a estrela emite, luz e energia em forma de calor, mas se referiu especificamente ao Sol, a estrela que aquece a Terra. No QF, ele alegou: "A luz é um tipo de onda eletromagnética, a partir dela conseguimos ver as estrelas e suas propriedades". No QF, o aluno respondeu de maneira geral e correta.

Sobre a gravidade, o educando disse: "Ela junta as moléculas fazendo com que se movimentem e criem forma até formar uma estrela". A Lei da Gravitação Universal foi mencionada durante a explicação da formação estelar, e essa é a razão provável da relação feita pelo aluno. Porém, ele esqueceu de mencionar que a gravidade é um fator determinante, presente em toda a existência de uma estrela, não apenas em sua formação. No QF, o aluno afirmou que a gravidade é importante para a formação estelar, mas acrescentou o assunto do movimento orbital das estrelas: "A gravidade faz as estrelas permanecerem em órbita e segura todos os elementos necessários para formar estrelas”. O aluno pode ter feito menção ao que foi explicado sobre as galáxias, quando dissemos que as estrelas orbitam o centro destas, assim como os planetas orbitam as estrelas.

O mesmo educando também demonstrou aquisição de conhecimento sobre a temperatura das estrelas no decorrer da atividade: "Então a cor das estrelas depende da temperatura". O aluno fez menção ao que foi dito durante a explicação do Diagrama $H R$, destacando que, a determinadas temperaturas, os objetos emitem luz visível e sua cor está relacionada com a quantidade de calor. No QI, o Aluno 1 afirmou: “A estrela é fria”. Já no $\mathrm{QF}$, o aluno foi taxativo em dizer que a temperatura da estrela é de $6.000^{\circ} \mathrm{C}$, mais uma vez fez menção ao Sol, sendo específico e não mostrando o contexto todo. Porém, é importante destacar que houve evolução positiva na resposta. 
Já a respeito da composição estelar, o estudante afirmou, no QI: “elementos biológicos". Durante a aula, declarou: “A estrela é feita de elementos químicos que ela mesma produz". Ainda que não tenha sido uma resposta completa, é evidente a evolução, quando fazemos a comparação com a resposta ao QI. Já no QF, o aluno anunciou: “O Sol é feito de elementos químicos: hidrogênio, hélio e carbono". Assim como nas questões anteriores, o aluno se referiu ao Sol, mas, desta vez, foi mais específico, dizendo quais são os elementos químicos presentes. Talvez tenha sido influenciado pela explicação da fusão nuclear, na qual indicamos que o hidrogênio e o hélio são os primeiros elementos a realizarem tal fenômeno, que será comentado a seguir.

Sobre a fusão nuclear, o aluno, no QI, comentou: “Agora, o Sol está fazendo hidrogênio por causa da fusão nuclear”. Percebemos que ele se confundiu ao afirmar que o Sol produz hidrogênio, uma vez que quase toda a quantidade hidrogênio presente no universo foi gerada no Big Bang. Porém, é possível notar que o aluno entendeu que as estrelas produzem novos elementos químicos, principalmente quando observamos a resposta ao QF: "Fusão nuclear é o combustível da estrela e produz elementos químicos".

O Aluno 1 também se manifestou sobre o equilíbrio hidrostático e declarou: "A gravidade e a pressão em equilíbrio fazem a estrela ficar parada, do jeito que a gente vê". $\mathrm{Na}$ aula, foi dito que as estrelas aumentam de tamanho cada vez que passam a ter outro elemento químico como fonte principal da fusão nuclear e, nesse momento, não estão em equilíbrio hidrostático. Porém, as estrelas passam muitos anos em equilíbrio, por isso é tão difícil observar alguma mudança nelas. Seguindo a mesma linha de pensamento, no QF, o aluno respondeu: "O equilíbrio hidrostático faz a estrela se manter dessa forma".

A respeito do fim das estrelas, no QI, o aluno afirmou não saber responder. Sua fala durante a aula e sua resposta no $\mathrm{QF}$ sobre esse assunto foram semelhantes: "As estrelas, quando morrem, podem explodir e transformar-se em outro elemento" e "Ela não vai ficar assim para sempre, vai explodir e se transformar em outro elemento", respectivamente. O aluno não foi muito específico em suas afirmações; entretanto, entendeu que as estrelas têm um fim e depois podem originar outros objetos. Foi explicado nas aulas que as estrelas menos massivas podem originar anãs brancas e as mais massivas podem explodir em uma Supernova, formando um Buraco Negro ou uma Estrela de Nêutrons. Talvez esses aspectos possam ter sido um pouco confusos para o educando, por isso ele os resumiu em "outro 
elemento"; todavia, não podemos deixar de notar que houve um avanço nas respostas, tendo em vista que o aluno não sabia responder a essa questão no início da atividade. 
Quadro 16 - Síntese da trajetória do Aluno 1 com base na evolução dos temas apresentados nas aulas

\begin{tabular}{|c|c|c|c|c|c|c|c|}
\hline \multicolumn{8}{|c|}{ A1 } \\
\hline Aula & $\begin{array}{l}\text { As estrelas emitem } \\
\text { luz e energia e } \\
\text { aquecem a Terra. }\end{array}$ & $\begin{array}{l}\text { Ela junta as } \\
\text { moléculas fazendo } \\
\text { com que se } \\
\text { movimenteme } \\
\text { criem forma até } \\
\text { formar uma estrela. }\end{array}$ & $\begin{array}{l}\text { Então a cor das } \\
\text { estrelas depende da } \\
\text { temperatura. }\end{array}$ & $\begin{array}{c}\text { A estrela é feita é de } \\
\text { elementos químicos } \\
\text { que ela mesma } \\
\text { produz. }\end{array}$ & $\begin{array}{l}\text { Agora, o Sol está } \\
\text { fazendo } \\
\text { hidrogênio por } \\
\text { causa da fusão } \\
\text { nuclear. }\end{array}$ & $\begin{array}{c}\text { A gravidade e a } \\
\text { pressão em } \\
\text { equilibrio fazem a } \\
\text { estrela ficar } \\
\text { parada, do jeito que } \\
\text { a gente vê. }\end{array}$ & $\begin{array}{l}\text { As estrelas, } \\
\text { quando morrem, } \\
\text { podem explodir e } \\
\text { transformar-se em } \\
\text { outro elemento. }\end{array}$ \\
\hline QF & $\begin{array}{l}\text { A luz é um tipo de } \\
\text { onda eletromagnética, } \\
\text { a partir dela } \\
\text { conseguimos ver as } \\
\text { estrelas e suas } \\
\text { propriedades. }\end{array}$ & $\begin{array}{l}\text { A gravidade faz as } \\
\text { estrelas } \\
\text { permanecerem em } \\
\text { orbita e segura } \\
\text { todos elementos } \\
\text { necessários para } \\
\text { formar estrelas. }\end{array}$ & $6.000^{\circ} \mathrm{C}$ & $\begin{array}{c}\text { O Sol é feito de } \\
\text { elementos químicos: } \\
\text { hidrogênio, hélio e } \\
\text { carbono. }\end{array}$ & $\begin{array}{l}\text { Fusão nuclear é o } \\
\text { combustível da } \\
\text { estrela e produz } \\
\text { elementos } \\
\text { químicos. }\end{array}$ & $\begin{array}{c}\text { O equilíbrio } \\
\text { hidrostático faz a } \\
\text { estrela se manter } \\
\text { dessa forma. }\end{array}$ & $\begin{array}{l}\text { Ela não vai ficar } \\
\text { assim para } \\
\text { sempre, vai } \\
\text { explodir e se } \\
\text { transformar em } \\
\text { outro elemento. }\end{array}$ \\
\hline
\end{tabular}

Fonte: Elaborado pela pesquisadora. 
O Quadro 17 apresenta os dados do Aluno 2 ao longo da atividade. Sobre a luz, o aluno, a princípio, afirmou: “A gente enxerga as estrelas através da luz”. No QF, percebemos um grande avanço em sua resposta, que foi mais elaborada: "Luz é uma forma de energia que viaja $300 \mathrm{mil} \mathrm{km/s.} \mathrm{Essa} \mathrm{é} \mathrm{tão} \mathrm{importante,} \mathrm{porque} \mathrm{é} \mathrm{por} \mathrm{meio} \mathrm{dela} \mathrm{que} \mathrm{conseguimos} \mathrm{visualizar}$ e estudar uma estrela no céu". Ele citou características importantes, como a velocidade da luz.

A respeito da gravidade, durante a aula, o discente falou de maneira simplória: " $A$ gravidade faz coisas caírem no chão". Já no QF, respondeu: “A gravidade [é] quem 'puxa' e 'junta' todos os gases, principalmente o hidrogênio para que deem origem a uma estrela". Mostrou um avanço importante ao mencionar a gravidade na formação estelar.

No que se refere à temperatura, o aluno respondeu ao QI de maneira semelhante ao Aluno 1 e disse: "Ela [a estrela] é fria", indicando deficiência nos conhecimentos prévios. Após discussão sobre os objetos incandescentes e a relação entre a cor e a temperatura, o Aluno 2 alegou: "As estrelas têm cores diferentes e cada cor é uma temperatura diferente". No QF, o estudante fez essa mesma relação: "Minha estrela é azul, logo sua temperatura é em torno de $25.000^{\circ} \mathrm{C}$ ". Por meio das duas últimas respostas, percebemos que o educando adquiriu conhecimento sobre o assunto, afirmando de modo correto que cor e temperatura estão diretamente relacionadas. Essa parte da atividade foi bastante discutida na turma. Foram utilizados exemplos na explicação, como as lâmpadas incandescentes, o que pode ter resultado na melhor compreensão por parte dos alunos.

Sobre a composição estelar, o Aluno 2 asseverou, no QI: "Ela é feita de átomos que se ligam e formam uma grande e brilhosa estrela. Átomos de gelo e cubos do mesmo". Notamos que a concepção do aluno inicialmente é bastante confusa, afirmando que a estrela é composta por gelo. Na explicação sobre a formação estelar, foi apresentado aos alunos o conceito de nuvem molecular, objeto que o Aluno 2 utilizou para descrever a composição estelar no decorrer da aula: “A nuvem molecular é gás e poeira, daí forma a estrela". Mesmo que seja uma explicação superficial, mostra que houve aquisição de conhecimento, pois foi incorporada a ideia de que a estrela é feita de gás e poeira.

No QF, o Aluno 2 descreveu: “A estrela é feita com a junção de vários gases, que, por sua vez, é constituída por poeira e hidrogênio". É possível perceber que ainda existe confusão sobre o assunto na resposta do aluno. Mais uma vez, ele se referiu aos tipos de 
gases; porém, não podemos deixar de notar um progresso se comparamos essa colocação com a feita no QI.

Em relação à fusão nuclear, o aluno afirmou inicialmente: “As estrelas que formam os elementos dentro de si e liberam a maioria dos elementos químicos”. Notamos que ele compreendeu que os elementos químicos são produzidos no interior das estrelas, mas também mencionou que as estrelas liberam os elementos químicos, referindo-se à explosão de Supernova, em que há liberação dos elementos químicos no espaço. No QF, o aluno redigiu uma resposta correta: "O combustível da estrela é o hidrogênio que se concentra no núcleo dela e faz fusão nucelar”. Dessa forma, indicou compreensão e aquisição de conhecimento.

O Aluno 2, ao tratar do equilíbrio hidrostático, alegou: "Ela conserva sua temperatura quando está em equilíbrio hidrostático e não morre". A afirmação apresenta falta de clareza sobre o tema. Foi explicado na aula que as estrelas modificam seu tamanho e sua temperatura quando não estão em equilíbrio hidrostático; porém, isso não está relacionado com a morte das estrelas, uma vez que a estrela perde o equilíbrio hidrostático algumas vezes durante sua existência, e isso não implica em seu fim. No QF, o estudante escreveu: "A gravidade e a pressão em equilíbrio fazem a estrela se manter dessa forma". Isso mostra o avanço na resposta.

Sobre o fim das estrelas, o Aluno 2 explicitou: "A estrela vai crescendo até morrer". De maneira semelhante, no QF, o aluno declarou: “A estrela não fica assim para sempre. Depois de produzir a maior parte dos elementos químicos dentro de si, elas podem crescer abundantemente e morrem". Talvez o aluno tenha sido influenciado pela explicação das Gigantes Vermelhas, estrelas que já estão em um estágio mais avançado e eram menores originalmente. É importante que o professor tenha cuidado nesse momento para que não haja falta de compreensão dos alunos e conclusões equivocadas. 
Quadro 17 - Síntese da trajetória do Aluno 2 com base na evolução dos temas apresentados nas aulas

\begin{tabular}{|c|c|c|c|c|c|c|c|}
\hline \multicolumn{8}{|c|}{ A2 } \\
\hline Atividade & Luz & Gravidade & Temperatura & $\begin{array}{c}\text { Composição das } \\
\text { estrelas }\end{array}$ & Fusão nuclear & $\begin{array}{l}\text { Equilíbrio } \\
\text { hidrostático }\end{array}$ & $\begin{array}{l}\text { Fim das } \\
\text { estrelas }\end{array}$ \\
\hline QI & & & Ela é fria. & $\begin{array}{l}\text { Ela é feita de } \\
\text { átomos que se } \\
\text { ligam e formam } \\
\text { uma grande e } \\
\text { brilhosa estrela. } \\
\text { Átomos de gelo e } \\
\text { cubos do mesmo. }\end{array}$ & & & $\begin{array}{l}\text { Não sei } \\
\text { responder. }\end{array}$ \\
\hline Aula & $\begin{array}{c}\text { A gente enxerga as } \\
\text { estrelas através da } \\
\text { luz. }\end{array}$ & $\begin{array}{c}\text { A gravidade faz } \\
\text { coisas caírem no } \\
\text { chão. }\end{array}$ & $\begin{array}{c}\text { As estrelas têm cores } \\
\text { diferentes e cada cor } \\
\text { é uma temperatura } \\
\text { diferente. }\end{array}$ & $\begin{array}{l}\text { A nuvem molecular } \\
\text { é gás e poeira, daí } \\
\text { forma a estrela. }\end{array}$ & $\begin{array}{l}\text { As estrelas que } \\
\text { formam os } \\
\text { elementos dentro } \\
\text { de si e liberam a } \\
\text { maioria dos } \\
\text { elementos } \\
\text { químicos. }\end{array}$ & $\begin{array}{c}\text { Ela conserva sua } \\
\text { temperatura } \\
\text { quando está em } \\
\text { equilíbrio } \\
\text { hidrostático e não } \\
\text { morre. }\end{array}$ & $\begin{array}{l}\text { A estrela vai } \\
\text { crescendo até } \\
\text { morrer. }\end{array}$ \\
\hline QF & $\begin{array}{l}\text { Luz é uma forma de } \\
\text { energia que viaja } 300 \\
\text { mil km/s. Essa é tão } \\
\text { importante, porque é } \\
\text { por meio dela que } \\
\text { conseguimos } \\
\text { visualizar e estudar } \\
\text { uma estrela no céu. }\end{array}$ & $\begin{array}{l}\text { A gravidade [é] } \\
\text { quem "puxa" e } \\
\text { "junta" todos os } \\
\text { gases, } \\
\text { principalmente o } \\
\text { hidrogênio para } \\
\text { que deem origem a } \\
\text { uma estrela. }\end{array}$ & $\begin{array}{c}\text { Minha estrela é azul, } \\
\text { logo sua temperatura } \\
\text { é em torno de } \\
25.000^{\circ} \mathrm{C} .\end{array}$ & $\begin{array}{l}\text { A estrela é feita } \\
\text { com a junção de } \\
\text { vários gases, que, } \\
\text { por sua vez, é } \\
\text { constituída por } \\
\text { poeira e hidrogênio. }\end{array}$ & $\begin{array}{l}\text { O combustível da } \\
\text { estrela é o } \\
\text { hidrogênio que se } \\
\text { concentra no } \\
\text { núcleo dela e faz } \\
\text { fusão nucelar. }\end{array}$ & $\begin{array}{l}\text { A gravidade e a } \\
\text { pressão em } \\
\text { equilíbrio fazem a } \\
\text { estrela se manter } \\
\text { dessa forma. }\end{array}$ & $\begin{array}{l}\text { A estrela não fica } \\
\text { assim para } \\
\text { sempre. Depois } \\
\text { de produzir a } \\
\text { maior parte dos } \\
\text { elementos } \\
\text { químicos dentro } \\
\text { de si, elas podem } \\
\text { crescer } \\
\text { abundantemente e } \\
\text { morrem. }\end{array}$ \\
\hline
\end{tabular}

Fonte: Elaborado pela pesquisadora. 
O Quadro 18 apresenta os dados do Aluno 3 ao longo da atividade. Referindo-se à luz, durante as aulas, o Aluno 3 mencionou: “A luz das estrelas chega até a gente e sentimos calor [...]. Podemos ver as estrelas por causa da luz", o aluno fala sobre a transferência de energia na forma de calor, assunto comentado na aula; porém, a resposta se vincula ao Sol, pois não podemos sentir o calor das outras estrelas. Respondendo ao QF, o Aluno 3 afirmou: "Luz é um tipo de onda, e sua importância é que podemos analisar do que a estrela é feita, etc.”. O aluno foi influenciado pela explicação dada na aula, quando dissemos que as ondas eletromagnéticas são a principal forma de estudarmos o universo, solucionando de maneira correta a pergunta e demonstrando compreensão sobre o tema.

Quanto à gravidade, o aluno apontou que as estrelas são esféricas em decorrência desse fenômeno: "Todas as estrelas são redondas por causa da gravidade puxar tudo para o centro, formando uma esfera". Essa leitura é bastante interessante, pois mostra que o aluno refletiu sobre o assunto e teve conclusões corretas. No QF, o estudante se estendeu mais: “Seu papel é 'segurar' todos elementos químicos necessários para sua formação e evolução, e também a gravidade faz com que a estrela entre em órbita, quanto maior sua massa, maior sua gravidade". Referiu-se à formação estelar, à orbita das estrelas e à Lei da Gravitação Universal, no que diz respeito à massa dos objetos. Por mais que a resposta não tenha sido muito detalhada, principalmente na menção à formação estelar, mostra que o aluno atentou aos detalhes comentados na aula.

Com relação à temperatura da estrela, o estudante disse, no QI, que ela é “quente”, indicando ter um pouco mais de noção sobre esse tema, comparado aos outros alunos. Durante a aula, o Aluno 3 declarou: "O Sol é muito quente, por isso a gente sente daqui da Terra". Logo, explicou sobre transferência de energia através das ondas eletromagnéticas. No QF, ponderou: “Acima de $6.000^{\circ} \mathrm{C}$ ". Mais uma vez temos referência ao Sol, talvez porque na aula este tenha sido bastante usado como exemplo, de maneira a influenciar os alunos, o que indica a necessidade de enfatizar que existem outras estrelas com características diferentes, mas com as mesmas propriedades.

Referindo-se à composição estelar, o Aluno 3, no QI, equivocou-se: "Magma e átomo". No decorrer da aula e no QF, contudo, alegou: “O Sol foi formado com hidrogênio, mas agora ele tem também hélio e carbono" e "Hidrogênio, Hélio e Carbono". 
Da mesma forma que no tópico anterior, as respostas se relacionam com a composição do Sol. Isso não deixa de mostrar aprendizado por parte do estudante, mas seria interessante utilizar outras estrelas também como exemplo.

No que diz respeito à fusão nuclear, o aluno relatou: "O hidrogênio se funde com hidrogênio formando o hélio, e a fusão do hélio com hélio forma o carbono, contribuindo com a expansão e a evolução da estrela". Apesar de essa fala ser superficial, indica que houve aprendizado sobre o assunto e que o aluno entendeu a base da fusão nuclear: dois elementos mais leves se fundem e formam um elemento mais pesado, o que gera uma quantidade de energia. É uma resposta satisfatória, uma vez que a atividade não foi muito longa, impedindo que o assunto pudesse ser tratado em detalhes. No QF, o aluno afirmou, também de maneira satisfatória: "O combustível é o hidrogênio, que faz fusão nucelar". Vale destacar que outros elementos podem realizar a fusão nuclear nas estrelas.

O Aluno 3, ao discorrer sobre o equilíbrio hidrostático, fez um comentário correto "A gente não percebe a mudança nas estrelas porque elas ficam muito tempo em equilíbrio hidrostático". Como foi explicado na aula, um dos motivos que fazem a estrela perder o equilíbrio hidrostático é a mudança do elemento que é a fonte principal da fusão nuclear, restabelecendo o equilíbrio depois. Todavia, as estrelas permanecem por muito tempo fundindo um mesmo elemento, em especial os mais leves, sendo difícil verificar qualquer alteração em sua aparência durante nosso tempo de vida. No QF, o aluno respondeu: "Ela se mantém dessa forma por que ela está em equilíbrio com a gravidade e pressão”. Esta última colocação também foi satisfatória, pois é o balanço entre gravidade e pressão interna que faz a estrela permanecer em equilíbrio.

Sobre o fim das estrelas, o aluno afirmou: "Quando uma estrela explode, ela libera os elementos químicos que vão formar outros planetas". Provavelmente, o aluno fez menção à explicação feita em aula de que algumas estrelas explodem em Supernova e liberam os elementos químicos no espaço, os quais formam os planetas. No QF, ele registrou: "Ela irá expandir e comer todos os planetas em volta e depois irá explodir e se tornar uma estrela anã, e essa explosão pode formar um buraco negro, uma nebulosa ou até mesmo outros planetas". Apesar de haver confusão em alguns aspectos da resposta, notamos que houve aquisição de conhecimento, pois o aluno entende que a estrela pode aumentar seu volume com o tempo, como ocorre quando passa a fundir outro elemento em seu núcleo. 
Foi explicado na aula que o Sol pode se tornar uma Gigante Vermelha, aumentando seu diâmetro de maneira que chegue à órbita de Saturno. Porém, constatamos falta de clareza com relação ao estágio final, no qual estrelas mais massivas explodem em Supernova e formam Buracos Negros ou Estrelas de Nêutrons e as menos massivas se tornam Nebulosas Planetárias e geram Anãs Brancas, por exemplo. $\mathrm{O}$ aluno parece não saber identificar muito bem a diferença entre esses aspectos e a formação dos planetas. Assim, há a necessidade de enfatizar durante a aula a relação e as variações desses aspectos. 
Quadro 18 - Síntese da trajetória do Aluno 3 com base na evolução dos temas apresentados nas aulas.

\begin{tabular}{|c|c|c|c|c|c|c|c|}
\hline \multicolumn{8}{|c|}{ A3 } \\
\hline Atividade & Luz & Gravidade & Temperatura & $\begin{array}{l}\text { Composição } \\
\text { das estrelas }\end{array}$ & Fusão nuclear & $\begin{array}{c}\text { Equilíbrio } \\
\text { hidrostático }\end{array}$ & $\begin{array}{l}\text { Fim das } \\
\text { estrelas }\end{array}$ \\
\hline QI & & & Quente. & Magma e átomo. & & & Não sei. \\
\hline Aula & $\begin{array}{c}\text { A luz das estrelas } \\
\text { chega até a gente e } \\
\text { sentimos calor }[\ldots . . .] \\
\text { Podemos ver as } \\
\text { estrelas por causa da } \\
\text { luz. }\end{array}$ & $\begin{array}{l}\text { Todas as estrelas } \\
\text { são redondas por } \\
\text { causa da gravidade } \\
\text { puxar tudo para o } \\
\text { centro, formando } \\
\text { uma esfera. }\end{array}$ & $\begin{array}{c}\text { O Sol é muito } \\
\text { quente, por isso a } \\
\text { gente sente daqui } \\
\text { da Terra. }\end{array}$ & $\begin{array}{c}\text { O Sol foi } \\
\text { formado com } \\
\text { hidrogênio, mas } \\
\text { agora ele tem } \\
\text { também hélio e } \\
\text { carbono. }\end{array}$ & $\begin{array}{l}\text { O hidrogênio se } \\
\text { funde com } \\
\text { hidrogênio } \\
\text { formando o hélio, } \\
\text { e a fusão do hélio } \\
\text { com hélio forma o } \\
\text { carbono } \\
\text { contribuindo com } \\
\text { a expansão e a } \\
\text { evolução da } \\
\text { estrela. }\end{array}$ & $\begin{array}{c}\text { A gente não } \\
\text { percebe a mudança } \\
\text { nas estrelas, porque } \\
\text { elas ficam muito } \\
\text { tempo em equilíbrio } \\
\text { hidrostático. }\end{array}$ & $\begin{array}{l}\text { Quando uma } \\
\text { estrela explode, } \\
\text { ela libera os } \\
\text { elementos } \\
\text { químicos que vão } \\
\text { formar outros } \\
\text { planetas. }\end{array}$ \\
\hline QF & $\begin{array}{l}\text { Luz é um tipo de } \\
\text { onda, e sua } \\
\text { importância é que } \\
\text { podemos analisar do } \\
\text { que a estrela é feita, } \\
\text { etc. }\end{array}$ & $\begin{array}{c}\text { Seu papel é } \\
\text { "segurar" todos } \\
\text { elementos químicos } \\
\text { necessários para sua } \\
\text { formação e } \\
\text { evolução, e também } \\
\text { a gravidade faz com } \\
\text { que a estrela entre } \\
\text { em órbita, quanto } \\
\text { maior sua massa, } \\
\text { maior sua } \\
\text { gravidade. }\end{array}$ & Acima de $6.000^{\circ} \mathrm{C}$. & $\begin{array}{c}\text { Hidrogênio, } \\
\text { Hélio e Carbono. }\end{array}$ & $\begin{array}{l}\text { O combustível é o } \\
\text { hidrogênio, que } \\
\text { faz fusão nucelar. }\end{array}$ & $\begin{array}{l}\text { Ela se mantém } \\
\text { dessa forma por que } \\
\text { ela está em } \\
\text { equilíbrio com a } \\
\text { gravidade e } \\
\text { pressão. }\end{array}$ & $\begin{array}{c}\text { Ela irá expandir e } \\
\text { comer todos os } \\
\text { planetas em volta } \\
\text { e depois irá } \\
\text { explodir e se } \\
\text { tornar uma estrela } \\
\text { anã, e essa } \\
\text { explosão pode } \\
\text { formar um buraco } \\
\text { negro, uma } \\
\text { nebulosa ou até } \\
\text { mesmo outros } \\
\text { planetas. }\end{array}$ \\
\hline
\end{tabular}

Fonte: Elaborado pela pesquisadora. 
Tendo em vista as trajetórias dos três alunos mencionados, procuramos fazer uma comparação entre elas. Visamos apresentar uma análise geral da evolução conceitual que represente o grupo estudado.

Figura 37 - Análise geral da evolução conceitual apresentada pelos três alunos

\begin{tabular}{|c|c|c|c|c|c|}
\hline Luz & $\begin{array}{c}\text { Onda } \\
\text { eletromagnética }\end{array}$ & Energia & $\begin{array}{l}\text { Nos faz enxergar } \\
\text { as estrelas }\end{array}$ & $\begin{array}{c}\text { Fornece dados } \\
\text { sobre estrelas }\end{array}$ & \\
\hline Temperatura & A estrela é fria & $\geq 6.000^{\circ} \mathrm{C}$ & $\begin{array}{l}\text { Relação entre } \\
\text { cor e } \\
\text { temperatura }\end{array}$ & & \\
\hline > Composição & $\begin{array}{l}\text { Elementos } \\
\text { biológicos }\end{array}$ & Gelo & Magma & $\begin{array}{l}\text { Elementos } \\
\text { químicos }\end{array}$ & Gás e poeira \\
\hline Fusão nt & $\begin{array}{l}\text { Hidrogênio faz } \\
\text { fusão nuclear }\end{array}$ & $\begin{array}{l}\text { Produz } \\
\text { elementos } \\
\text { químicos }\end{array}$ & & & \\
\hline $\begin{array}{c}\text { Equilíbrio } \\
\text { Hidrostático }\end{array}$ & $\begin{array}{l}\text { Pressão } \\
\text { X } \\
\text { Gravidade }\end{array}$ & $\begin{array}{l}\text { Faz a estrela } \\
\text { ficar "parada" }\end{array}$ & & & \\
\hline $\begin{array}{l}\text { Fim das } \\
\text { estrelas }\end{array}$ & $\begin{array}{c}\text { Cresce até } \\
\text { morrer }\end{array}$ & Explosão & $\begin{array}{l}\text { Libera } \\
\text { elementos } \\
\text { químicos }\end{array}$ & Buraco Negro & Anã Branca \\
\hline
\end{tabular}

Fonte: Elaborado pela pesquisadora.

A respeito da $l u z$, os alunos iniciaram de maneira positiva afirmando que se trata de uma onda eletromagnética e que transmite energia. Em seguida, relacionaram a luz com a possibilidade de enxergar as estrelas e, por fim, identificaram-na como uma fonte de informações sobre as estrelas. Houve uma evolução importante, uma vez que um dos objetivos da atividade é fazer com que os alunos entendam as relações entre tais temas e a evolução estelar.

O avanço do conceito de gravidade foi notório, pois inicialmente os alunos a relacionavam, principalmente, à queda dos objetos, mostrando que seu conhecimento sobre o fenômeno estava restrito a seu cotidiano. Em geral, as aulas sobre gravitação nas escolas não exploram muito o assunto. Em sua grande maioria, os materiais didáticos tratam, no tema da gravitação, da queda livre e da atração entre duas partículas, o que torna limitada a visão dos estudantes a respeito do tema. Ao final da atividade, os educandos demonstraram de maneira adequada a importância desse fenômeno no ciclo evolutivo das estrelas. Um dos principais objetivos da atividade foi mostrar aos alunos a 
universalidade da Física, ou seja, os conceitos aprendidos no Ensino Médio não só são válidos aqui na Terra, mas em todo o universo, inclusive na formação e evolução estelar. A gravidade é um bom exemplo para constatar esse aspecto, sendo visível o progresso dos alunos nesse tópico ao longo da atividade.

Sobre a temperatura, também se observou uma evolução importante, pois inicialmente houve a afirmação de que a estrela é fria. Posteriormente, os alunos mencionaram o valor $\geq 6.000^{\circ} \mathrm{C}$, indicando a temperatura superficial do Sol. Ao final da atividade, mostraram de maneira correta a relação entre cor e temperatura.

O tema da composição estelar também merece destaque. Inicialmente, não foi demonstrado qualquer conhecimento sobre tal característica, sendo indicado "Elementos biológicos" ou "Gelo", por exemplo, como a constituição desse astro. No decorrer da atividade, no entanto, os alunos afirmaram "elementos químicos", após uma discussão introdutória sobre fusão nuclear. Ao final, foi mencionado "gás e poeira", mostrando um resultado adequado.

No que se refere à fusão nuclear, os estudantes apontaram, após uma breve explicação sobre o primeiro elemento que realiza tal fenômeno em uma estrela primária, "Hidrogênio faz fusão nuclear". No final da atividade, foi afirmado: "Produz elementos químicos". Talvez esse assunto tenha sido um dos que mais se destacaram para os alunos, pois se trata de algo importante que não é mencionado em grande parte das escolas. Contudo, seu produto é bastante estudado nas aulas de Ciências: os elementos químicos da tabela periódica. Isso fez os alunos refletirem sobre sua origem, algo que, aparentemente, não haviam questionado anteriormente.

O Equilíbrio Hidrostático representa mais um conceito novo para os estudantes; no entanto, os resultados apontam aquisição de conhecimento. Após a introdução sobre o assunto, foi mencionada o conflito "Pressão x Gravidade", ou seja, a "disputa" entre a pressão interna da estrela e sua própria gravidade. Ao final, os discentes alegaram: "Faz a estrela ficar parada". Isto é, disseram que o equilíbrio entre as forças faz a estrela se manter estável, indicando resultados adequados para esse tema.

Os alunos também apresentaram respostas favoráveis sobre o fim das estrelas. Inicialmente, disseram: “Cresce até morrer". Notamos que, a essa altura da aula, alguns termos, como Gigante Vermelha, já haviam sido apresentados aos educandos. Em seguida, temos as colocações: "Explosão" e "Libera elementos químicos". Ao final, aparecem as seguintes afirmações: "Buraco Negro" e "Anã Branca". Na aula, foram mencionadas também as Estrelas de Nêutrons e as Nebulosas Planetárias, conceitos que, 
aparentemente, não alcançaram seu grau de sucesso, talvez por terem sido apresentados de maneira um pouco superficial. Ainda assim, podemos considerar apropriados os resultados desse tema, uma vez que os alunos fizeram relação entre a evolução da estrela em seu tempo de existência e citaram características importantes sobre os processos finais do ciclo estelar.

Apesar do tempo limitado e do assunto nada trivial (evolução estelar), podemos dizer que houve significativa aquisição de conhecimento por parte dos estudantes, uma vez que, em determinados momentos, os alunos fizeram menção a características pontuais e importantes do ciclo estelar.

Considerando o que foi apresentado neste trabalho, o quadro 19 mostra os temas abordados em cada aula e as respectivas percepções e conhecimentos dos alunos no decorrer da atividade.

$\mathrm{Na}$ intenção de contribuir para que essa atividade possa ser aplicada na sala de aula, será feita uma breve análise do quadro. Discutiremos de maneira mais aprofundada os temas apresentados em cada aula.

Na aula 1 foi apresentada uma breve introdução à Astronomia. Iniciamos com uma discussão sobre o céu estrelado e as constelações, mencionamos também a história da Astronomia e outras culturas que possuem suas próprias constelações. Em seguida, explicamos sucintamente os conceitos de magnitude e fluxo e o modo como estes afetam nossa percepção; por exemplo, dissemos que nem sempre a estrela menos brilhante está mais distante da Terra. Na última parte, discutimos a relação entre cor e temperatura e tratamos da radiação. Mostramos o espectro eletromagnético aos alunos, expusemos, entre outras coisas, que cada frequência possui uma característica singular.

Na aula 2, começamos a explicação sobre a formação estelar. Porém, antes de falar sobre os primeiros processos, apresentamos de maneira sucinta o Diagrama $H R$, de forma a mostrar que as estrelas se modificam ao longo de sua existência, além de possuírem cores e tamanhos bastante variados. Nesse momento, mencionamos resumidamente o "trajeto" das estrelas no Diagrama $H R$, de acordo com os processos evolutivos. Depois, expusemos aos estudantes o conceito de nuvem molecular, suas principais características e o modo como se principia a formação das estrelas. O Teorema do Virial, apesar de muito importante para a formação estelar, é um assunto mais complexo; portanto, simplificar termos e utilizar exemplos do cotidiano pode fazer toda diferença, apesar de ser um grande desafio. 
Quadro 19 - Síntese dos conhecimentos e das percepções esperados a partir da realização da atividade

\begin{tabular}{|c|c|c|}
\hline Aula & Tema & Percepções e Conhecimentos \\
\hline 1 & $\begin{array}{l}\text { - } \text { Céu estrelado } \\
\text { - Constelações } \\
\text { - } \text { Magnitude } \\
\text { - } \text { Fluxo } \\
\text { - Cor e temperatura } \\
\text { - Radiação }\end{array}$ & $\begin{array}{l}\text { Entender o que são as galáxias e suas ordens de } \\
\text { grandeza. } \\
\text { Compreender o contexto histórico e cultural das } \\
\text { constelações. } \\
\text { Assimilar os conceitos de magnitude e fluxo e a } \\
\text { relação destes com cor e temperatura. } \\
\text { Conhecer o que é radiação e qual sua relação com } \\
\text { as estrelas e o estudo da Astronomia. }\end{array}$ \\
\hline 2 & $\begin{array}{l}\text { - } \text { Diagrama } H R \\
\text { - } \text { Nuvem molecular } \\
\text { - } \text { Teorema do Virial } \\
\text { - Gravidade e pressão }\end{array}$ & $\begin{array}{l}\text { Compreender o Diagrama } H R \text { e o modo como ele } \\
\text { se relaciona com a evolução estelar. } \\
\text { Entender a formação das estrelas e o início de seu } \\
\text { ciclo evolutivo, desde a nuvem molecular até o } \\
\text { Teorema do Virial. } \\
\text { Entender a relação entre gravidade e pressão e a } \\
\text { forma como tais fatores interferem na evolução } \\
\text { estelar. }\end{array}$ \\
\hline 3 & $\begin{array}{l}\text { - Fusão Nuclear } \\
\text { - } \text { Produção de energia } \\
\text { - Equilíbrio Hidrostático } \\
\text { - Gigante Vermelha }\end{array}$ & $\begin{array}{l}\text { Aprender a formação dos elementos químicos por } \\
\text { meio da fusão nuclear e a maneira como isso resulta } \\
\text { na produção de energia. } \\
\text { Entender o que é Equilíbrio Hidrostático e qual sua } \\
\text { importância para a evolução das estrelas. } \\
\text { Compreender o estágio final da evolução estelar e } \\
\text { o conceito de Gigante Vermelha. }\end{array}$ \\
\hline 4 & $\begin{array}{l}\text { - Nebulosa Planetária } \\
\text { - Anã Branca } \\
\text { - Explosão de Supernova } \\
\text { - Buraco Negro/Estrela de } \\
\text { Nêutrons }\end{array}$ & $\begin{array}{l}\text { Entender os fatores que levam à formação de uma } \\
\text { Nebulosa Planetária e quais suas características. } \\
\text { Compreender o conceito de Anã Branca. } \\
\text { Diferenciar o fim de estrelas muito e pouco } \\
\text { massivas. } \\
\text { Entender o conceito de Explosão de Supernova. } \\
\text { Compreender e diferenciar um Buraco Negro e } \\
\text { uma Estrela de Nêutrons. }\end{array}$ \\
\hline
\end{tabular}

Fonte: Elaborado pela pesquisadora.

No final da aula 2, discutimos a definição do conceito de gravidade e a Lei da Gravitação Universal. Também introduzimos o conceito de pressão. Comentamos como esses dois fenômenos podem estar relacionados. O foco principal foi mostrar como a gravidade e a pressão fazem as moléculas da nuvem molecular interagirem entre si e iniciarem o processo extraordinário de formação das estrelas.

A evolução estelar, após sua formação, foi apresentada na aula 3. Esta abordou, $a$ priori, o conceito de fusão nuclear, fenômeno que determina o momento em que a estrela 
está formada. Houve uma breve discussão sobre a tabela periódica, levando a uma reflexão sobre a maneira como tais elementos surgiram no universo. Posteriormente, explicamos o processo em si e descrevemos a forma como ele produz energia para a estrela. Destacamos que estrelas de massas diferentes realizam a fusão nuclear de maneira distinta: estrelas de grande massa possuem tempo de existência menor, produzem mais energia e, por isso, são mais quentes e azuis, mas são capazes de formar uma variedade maior de elementos químicos.

Em seguida, apresentamos o Equilíbrio Hidrostático e o modo como ele contribui para que a estrela se mantenha estável. Relacionamos esses dois fenômenos a fim de mostrar que a perda do equilíbrio hidrostático se dá a partir do momento em que a estrela passa a fundir um novo elemento mais pesado, o que resulta na modificação de seu diâmetro e de sua densidade, até que retome o equilíbrio. No final da aula, foi explicado o conceito de Gigante Vermelha, indicamos como ela representa um estágio mais avançado na evolução das estrelas e decorre da atividade dos processos tratados anteriormente.

Na quarta e última aula, discorremos sobre o fim das estrelas. Primeiramente, explicamos o processo final do ciclo das estrelas de menor massa, como o Sol, por exemplo. Tais estrelas, após se tornarem Gigantes Vermelhas, não são capazes de fundir elementos mais pesados do que o hélio, gerando uma Anã Branca a partir de uma Nebulosa Planetária. O último tópico a ser tratado na atividade foi o fim das estrelas de maior massa. Foi explicado como elas fundem elementos mais pesados, até chegar ao ferro, momento em que a estrela perde seu equilíbrio e explode em uma Supernova. Realçamos a quantidade exorbitante de energia liberada nessa explosão, que é capaz, inclusive, de produzir o restante dos elementos químicos e pode ter um brilho maior do que o de uma galáxia. Também é importante dizer que as estrelas de grande massa representam apenas uma mínima porção da quantidade de estrelas presentes no universo.

Posteriormente, expusemos os resultados da explosão de Supernova: a Estrela de Nêutrons ou o Buraco Negro. Apontamos que a diferença para a formação de cada uma é a massa inicial da estrela. Foi explicada a origem do nome das Estrelas de Nêutrons, também chamadas de Pulsares, e suas principais características. Devido ao fato de os buracos negros despertarem mais o interesse dos alunos nesta aula, foi dedicado maior tempo para tratar do assunto. Foram mencionados os conceitos de velocidade de escape para explicar como os buracos negros não emitem luz, horizonte de eventos, entre outros. Para finalizar, relatamos sobre o Buraco Negro supermassivo presente no centro da Via 
Láctea. Apesar de os alunos interagirem durante toda a atividade, ao final da explicação, foi dedicado um curto momento para perguntas, o que foi bastante produtivo. 


\section{CONSIDERAÇÕES FINAIS}

Neste trabalho, foi desenvolvida uma breve sequência de aulas sobre Astrofísica Estelar no Ensino Médio, com o intuito de investigar os conhecimentos prévios dos alunos e sua evolução durante a atividade. Assim sendo, inicialmente fizemos um levantamento e uma análise de teses e dissertações, artigos de periódicos e publicações internacionais, a fim de enriquecer esta pesquisa.

Por meio da revisão bibliográfica, foi possível perceber algumas lacunas no ensino da Astrofísica Estelar, como a falta de trabalhos voltados para o assunto, tanto no âmbito nacional quanto no internacional. Pouco encontramos sobre estratégias para a inclusão da Astrofísica Estelar na educação básica. Entretanto, a utilização de outros referenciais teóricos pode aprimorar o estudo e propiciar novas questões acerca do assunto.

Notamos deficiência nas propostas do governo para a educação pública. Não há menção à evolução estrelar nos PCN de Física para o Ensino Médio, e a quantidade de material sobre o tema presente em outros documentos é bastante limitada.

Contudo, os resultados da aplicação do tema em sala de aula mostraram que uma parcela significativa dos discentes adquiriu conhecimento sobre a Astrofísica Estelar, além do interesse em saber outros aspectos do assunto. A atividade ocorreu apropriadamente durante as aulas de Física do Ensino Médio e tratou de tópicos relacionados ao conteúdo programático da disciplina, como gravitação, termodinâmica e ondas, por exemplo, indicando uma interessante alternativa para a apresentação desses conceitos aos alunos em formação.

A aplicação de dois questionários, o inicial e o final, na atividade foi determinante para que observássemos a evolução dos alunos mediante a comparação das respostas. Ao final, grande parte dos alunos respondeu às questões de maneira correta e mais específica. Além disso, as gravações dos áudios das aulas e as anotações proporcionaram mais detalhes, que foram importantes na investigação da aquisição de conhecimentos ao longo das aulas. Informações obtidas durante a atividade a partir da interação dos alunos mostraram profundo interesse, também ocorreram eventuais discussões extraclasse.

A partir da realização desta pesquisa, foram notadas importantes limitações relacionadas à instituição de ensino. Houve certa dificuldade para agendar as aulas, uma vez que estas deveriam estar de acordo com a programação da disciplina, esse também foi o motivo por ter sido oferecido apenas o período de quatro aulas. Além disso, havia apenas uma sala na escola com projetor para a apresentação de slides, que é dividida entre 
os todos os professores. A sala também era utilizada para reuniões internas, e houve situações em que se perdeu tempo de aula em decorrência disso. No Ensino de Ciências, especialmente de Astronomia, é interessante a utilização de recursos visuais, como imagens e vídeos, e a realização de aulas em laboratório para a aprendizagem dos alunos. Porém, percebemos que as escolas nem sempre estão preparadas para suprir as necessidades exigidas para um ensino de qualidade.

Outro fator limitante foi o conhecimento prévio dos alunos sobre Matemática e Física, que se mostrou deficiente. Alguns tópicos da atividade demandaram um tempo maior do que o previsto para que pudesse ser feita uma revisão com os alunos sobre a Matemática, como foi o caso da equação do fluxo. Outros assuntos mais complexos tiveram que ser citados apenas conceitualmente, pois exigiam uma base matemática mais avançada, como foi o caso do Teorema do Virial, aspecto significativo da evolução estelar, que exigia um período maior do que o fornecido. Para suprir tais lacunas, talvez fosse interessante que os estudantes realizassem mais tarefas ou atividades que saiam da rotina da sala de aula, de maneira a tornar o estudo mais atrativo.

Com relação à sequência de aulas apresentada, houve retorno positivo por parte dos alunos. A utilização de imagens e analogias contribuiu para a compreensão dos alunos, fazendo com que estes relacionassem aspectos do cotidiano com questões da evolução estelar. A quantidade de aulas não favoreceu o projeto, pois uma maneira mais adequada para ensinar sobre as estrelas na escola é distribuir aulas ao longo de um período letivo, acompanhando, na medida do possível, a evolução dos conceitos de Física abordados. Por esse motivo, alguns assuntos tiveram que ser tratados de maneira superficial e resumida, como foi o caso do Diagrama $H R$ e das Estrelas de Nêutrons.

Apesar dos obstáculos, a atividade proporcionou resultados bastante positivos, os alunos participaram de maneira ativa e apresentaram certa evolução em conceitos específicos da Física e da evolução estelar. Em sua grande maioria, os estudantes tiveram maior aceitação dos aspectos conceituais envolvidos, demonstrando uma base matemática fraca. Contudo, levando em conta a escassa quantidade de aulas, constatamos o desenvolvimento dos alunos no período da atividade. 


\section{REFERÊNCIAS}

AGAN, L. Stellar ideas: exploring students' understanding of stars. Astronomy Education Review, [S.1.], v. 3, p. 77-97, mar. 2004.

AROCA, S. C.; SILVA, C. C. Ensino de astronomia em um espaço não formal: observação do Sol e de manchas solares. Revista Brasileira de Ensino de Física, São Paulo, v. 33, n. 1, 2011.

BAILEY, J. M. Development of a concept inventory to assess students' understanding and reasoning difficulties about the properties and formation of stars. Astronomy

Education Review, Cambridge, v. 6, n. 2, mar. 2008.

BAILEY, J. M. et al. College students' preinstructional ideas about stars and star formation. The Astronomy Education Review, Cambridge, 2009.

BARDIN, L. Análise de Conteúdo. Portugal: Edições 70, 2011.

BARNARD 68. 2012. 1 fotografia. Disponível em: < http://www.astropt.org/2012/01/29/barnard-68/>. Acesso em: 10/06/2018.

BAZETTO, M. C. Q.; BRETONES, P. S. A cosmologia em teses e dissertações sobre Ensino de Astronomia no Brasil. In: SIMPÓSIO NACIONAL DE EDUCAÇÃO EM ASTRONOMIA, 1., 2011, Rio de Janeiro. Anais... São Paulo: SAB, 2011.

BRASIL. Ministério da Educação. Secretaria de Educação Média e Tecnológica. Parâmetros Curriculares Nacionais para o Ensino Médio. Brasília, 1998.

BRASIL. Ministério da Educação. Secretaria de Educação Média e Tecnológica. Parâmetros Curriculares Nacionais (Ensino Médio). Brasília, 2000.

BRASIL. Ministério da Educação. Secretaria de Educação Média e Tecnologia. PCN+, Orientações curriculares para o Ensino Médio: Ciências da Natureza, Matemática e suas Tecnologias. Brasília, 2006.

CANIATO, R. O Céu. São Paulo: Átomo, 2011.

CARACTERÍSTICAS BÁSICAS DE UMA ONDA, ENTRE ELAS A AMPLITUDE E O COMPRIMENTO DE ONDA. 2017. 1 ilustração. Disponível em: <https://kaperseus-

images.s3.amazonaws.com/162fdc69c05f43654aabc5f36714446782a4ccb5.png>. Acesso em: 23/06/2018.

DAVIS, J. Amas-Etoiles-Pleiades. In: ASTRONOO. As Plêaides. Astronoo, [S.1.], 1 jun. 2013. 1 fotografia. Disponível em:

<http://www.astronoo.com/pt/artigos/pleiades.html>. Acesso em: 23/06/2018. 
DIAGRAMA H-R. 2018. 1 ilustração. Disponível em: $<$ https://www.hablandodeciencia.com/articulos/2018/02/13/obafgkm-y-el-diagrama-hr/>. Acesso em: 09/10/2017.

ESO-L. O-type protostar outflow circumstellar disc. In: ASTORNOMY NOW. Astronomers identify a young heavyweight star in the Milky Way. Astronomy Now, [S.1.], 22 ago. 2016. 1 fotografia. Disponível em:

<https://astronomynow.com/2016/08/22/astronomers-identify-a-young-heavyweightstar-in-the-milky-way/>. Acesso em: 09/10/2017.

FUTURANI, T. A student-constructed three-dimensional model of stars in nearby space. Astronomy Education Review, Cambridge, v. 7, n. 2, p. 122-131, 2009.

HORVATH, J. E. O ABCD da Astronomia e Astrofísica. São Paulo: Livraria da Física, 2008 .

Uma proposta para o ensino da astronomia e astrofísica estelares no Ensino Médio. Rev. Bras. Ensino Fís., São Paulo, v. 35, n. 4, p. 1-8, 2013.

IACHEL, G. O conhecimento prévio de alunos do Ensino Médio sobre as estrelas. Revista Latino-Americana de Educação em Astronomia, Bauru, n. 12, p. 7-29, 2011.

IACHEL, G.; LANGHI, R.; SCALVI, R. M. F. Concepções alternativas de alunos do ensino médio sobre o fenômeno de formação das fases da Lua. Revista LatinoAmericana de Educação em Astronomia, 2008.

IMAGE. [20--]. 1 fotografia. Disponível em:

$<$ https://image.jimcdn.com/app/cms/image/transf/dimension=436x 10000:format=jpg/pa th/s8d05530234f9682f/image/ide4bb680a1e1a644/version/1514384399/image.jpg>.

Acesso em: 20/06/2018.

LAMPADA. 2017. 1 fotografia. Disponível em:

$<$ https://abrilcasa.files.wordpress.com/2016/11/lampada.jpeg?quality=95\&strip=all\&stri p=info $>$. Acesso em: 20/06/2018.

LANGHI, R. Educação em Astronomia: da revisão bibliográfica sobre concepções alternativas à necessidade de uma ação nacional. Caderno Brasileiro de Ensino de Física, Campo Grande, v. 28, n. 2, p. 373-399, 2011.

Um estudo exploratório para a inserção da Astronomia na formação de professores dos anos iniciais do Ensino Fundamental. 2004. 240 f. Dissertação (Mestrado em Educação para a Ciência)- Faculdade de Ciências, Universidade Estadual Paulista “Júlio de Mesquita”, Bauru, 2004.

LANGHI, R.; NARDI, R. Formação de professores e seus saberes disciplinares em Astronomia essencial nos anos inicias do Ensino Fundamental. Revista Ensaio, Belo Horizonte, v. 12, n. 2, p. 205-224, maio/ago. 2010 
LANGHI, R.; NARDI, R. Educação em Astronomia: repensando a formação de professores. São Paulo: Escrituras Editora, 2012.

LELLIOTT, A.; ROLLNICK, M. Big Ideas: a review of astronomy education research 1974-2008. International Journal of Science Education, [S.1.], v. 32, n. 13, p. 17711799, 2010.

LÜDKE, M.; ANDRÉ, M. Pesquisa em Educação: abordagens qualitativas. São Paulo: EPU, 1986.

PASACHOFF, J. M. What Should College Students Learn? Astronomy Education Review, Cambridge, v. 1, n. 1, p. 124-130, out. 2002.

REINFELD, E. L.; HARTMAN, M. A. Kinesthetic life cycle of stars. Astronomy Education Review, Cambridge, v. 7, n. 2, p. 158-175, 2009.

SÃO PAULO. Secretária da Educação. Currículo do Estado de São Paulo: Ciências Humanas e suas tecnologias. São Paulo, 2011.

Secretaria da Educação. Material de apoio ao currículo do Estado de São Paulo: Caderno do Professor; Filosofia, Ensino Médio, 1ª série. São Paulo, 2014. 